\title{
Viséan Lithostrotionidae (Rugosa) from Zonguldak and Bartın (NW Turkey)
}

\author{
JULIEN DENAYER
}

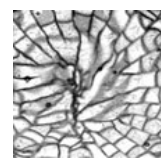

\begin{abstract}
In Northwestern Turkey, the Mississippian (Lower Carboniferous) Yllanlı Formation is composed of variegated shallow-water limestone containing rugose corals, tabulate corals and brachiopods. Six sections were sampled in the Zonguldak and Bartın areas, from east to west, there are Süzek, Topluca, Gökgöl, Kokaksu, Ulutam and Kisla sections. Among the rugose corals, a rich and diversified assemblage of Lithostrotionidae has been collected. The latter contains the species: Nemistium cf. affine, Siphonodendron ondulosum, S. martini, S. irregulare, S. pauciradiale, S. asiaticum, $S$. rallii sp. nov., S. scaleberense, S. kleffense, S. aff. kleffense, Lithostrotion araneum, L. vorticale, L. sp. and L. potii sp. nov. During the Moliniacian it is proposed that subcerioid colonies of $S$. ondulosum gave rise to cerioid colonies of Lithostrotion potii sp. nov., the latter constituting the oldest species of the genus previously considered to be Livian to Warnantian in age. This discovery led to an emendation of the phyletic lineage of the Lithostrotionidae. The biostratigraphy based on rugose corals indicates a Moliniacian (early Viséan) and Warnantian (late Viséan) age of the deposits with the absence of the intervening Livian (middle Viséan). - Key words: Lower Carboniferous, Viséan, Pontides, Turkey, rugose corals, Lithostrotion, Siphonodendron, Nemistium.
\end{abstract}

DENAYER, J. 2014. Viséan Lithostrotionidae (Rugosa) from Zonguldak and Bartın (NW Turkey). Bulletin of Geosciences 89(4), 737-771 (19 figures, 1 table). Czech Geological Survey, Prague. ISSN 1214-1119. Manuscript received December 27, 2013; accepted in revised form January 21, 2014; published online September 9, 2014; issued September 30, 2014.

Julien Denayer, Service de Paléontologie animale et humaine, Département de Géologie, Université de Liège, Bât. B18, Allée du Six-Août, Sart Tilman, B-4000 Liège, Belgium, and Integrated Palaeoenvironmental Research Group, School of Earth Sciences, University of Queensland, QLD 4072 St-Lucia, Australia; julien.denayer@ulg.ac.be

The lithostrotionids, namely the cerioid Lithostrotion and phaceloid Siphonodendron, are probably the most abundant and widespread colonial rugose coral genera of the $\mathrm{Vi}$ séan. They have been described from Belgium (Poty 1981, 1984), Brittany (Vuillemin 1990), N France (Poty \& Hannay 1994), British Isles (Nudds 1979, Semenoff-TianChansky \& Nudds 1979), Poland (Khoa 1977), S France (Aretz 2002), S Spain (Rodríguez \& Falces 1992, Rodríguez et al. 2002), N Africa (Semenoff-Tian-Chansky 1985, Aretz 2010, Aretz \& Herbig 2010, Rodríguez et al. 2013), S Turkey (Denayer 2012), Ukrainian Donets Basin (Vassiljuk 1960), Siberian Omolon (Conil et al. 1982), Kuznetsk Basin (Dobroljubova et al. 1966), Japan (Minato 1955), SE China (Fan et al. 2003) and W China (Lin \& Rodriguez 1993). Australian (Jull 1974, Webb 1990) and Canadian (Bamber 1966) forms are homeomorphic taxa evolving in a distinct stock of "lithostrotionid" corals (Webb 1994, Fedorowski 2008, Poty 2010). Both require revision.

In NW Turkey, some lithostrotionid corals were first noticed by Ralli (1895) and Tokay (1954) then described by Charles (1933) in his regional study of Zonguldak and
Bartın. He figured three Siphonodendron species: under the names Lithostrotion martini, Lithostrotion aff. irregulare and Lophophyllum fraiponti nov. sp. Charles's collection and newly collected material from Charles's localities around Bartın and Zonguldak are described in the present paper. The family is richer than noticed in previous papers (Charles 1933, Ünsalaner-Kiragli 1958, Dîl \& Konyali 1978, Denayer 2011). Moreover, Turkish specimens are clear Eurasian lithostrotionids and most of them belong to well-established W European species. Their stratigraphic distribution also matches that of W Europe, thus the use of Belgian substage names (as proposed by Poty et al. 2013a) is justified.

\section{Geological settings}

The northern part of Turkey - the Pontides - is composed of two tectonic units: the Istanbul-Zonguldak Zone and the Sakarya Zone, separated from each other by a major fault named the Intra-Pontide "Suture" (Fig. 1). Göncüoğlu et al. (1997) divided the Istanbul-Zonguldak Zone into the 


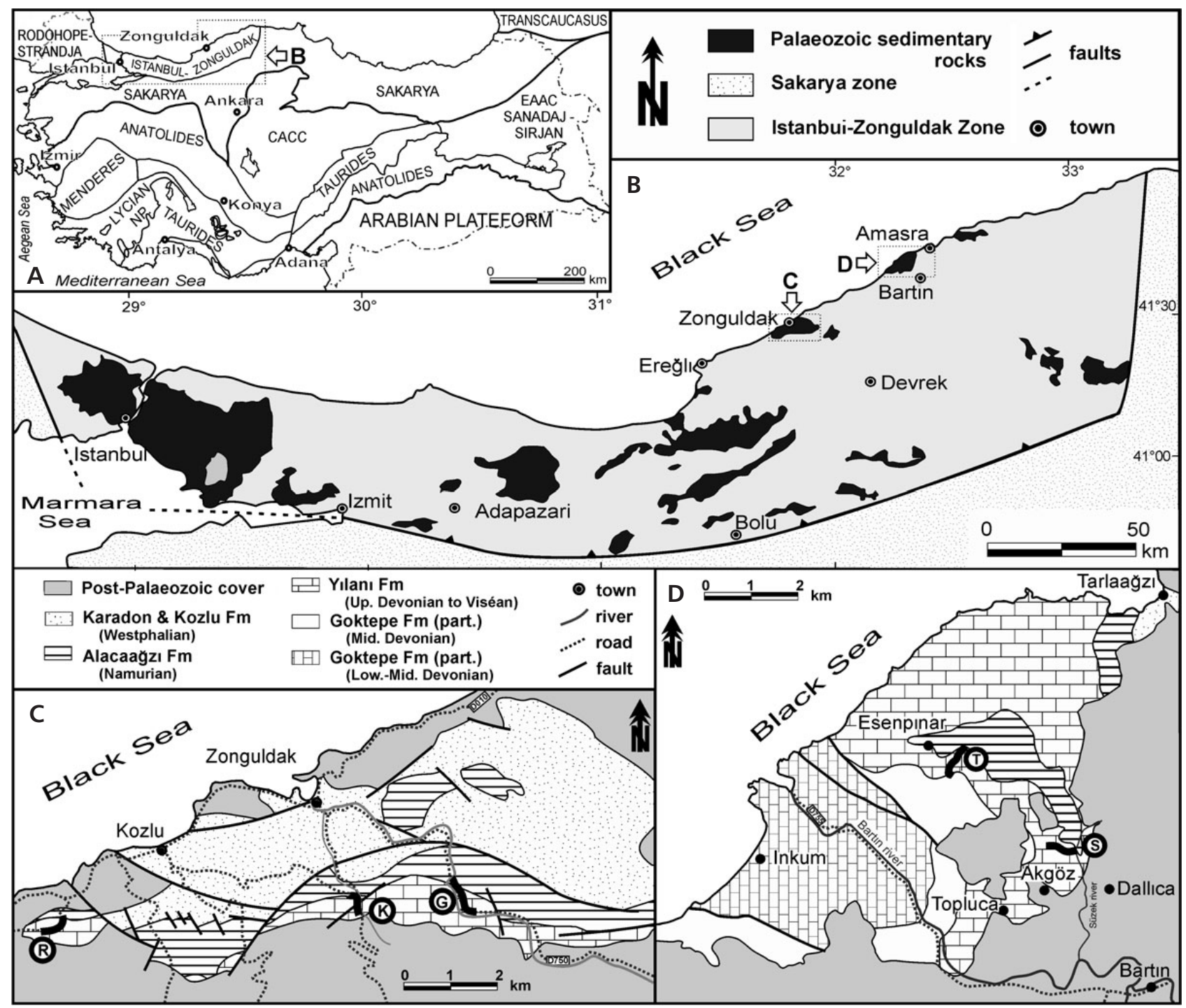

Figure 1. A - general structural map of Turkey (modified after Görür \& Tüysüz 2001, Moix et al. 2008 and Okay 2008). B - geological map of the Istanbul-Zonguldak Zone (modified after Okay et al. 2006) with the position of the Zonguldak and Bartın areas. $\bullet$ C - simplified geological map of the Zonguldak area (redrawn after Hoșgörmez 2007 and Charles 1933) with the location of the sampled sections (G - Gökgöl section, K - Kokaksu section, U - Ulutam, R - Kisla section). D - simplified geological map of the Bartın area (redrawn after Tokay 1954) with the location of the sampled sections (T - Topluca section, S - Süzek section). Abbreviations: CCAC - Central Anatolian Cristalline Complex, EAAC - East Anatolian Accretionnary Complex, Lycian Np. - Lycian Nappes.

Istanbul Terrane and Zonguldak Terrane. However, this hypothesis is not unanimously accepted (e.g. Okay et al. 2006) and the alternative concept interpreted the Istanbul and Zonguldak areas as the two sides of one single terrane. The Istanbul Zone recorded basinal sediments during Devonian and Carboniferous times while the Zonguldak Zone shows shallow-water facies.

In the Istanbul Zone, the Carboniferous is represented by the Baltalimanı (Tournaisian), Trakya (TournaisianViséan) and Gümüșdere (Namurian) formations representing Paeckelmann's (1938) “Thrazische Serie”. The Trakya Formation is dominated by siliciclastics and only two limestone lenses are known: the Heybeliada Limestone (lower
Viséan, Mamet 1973) and Cebecikoy Limestone (lower Viséan after Okuyucu et al. 2013 or middle Viséan after Mamet 1973). These limestones possibly correspond to olistoliths (Özgül 2012, Okuyucu et al. 2013). The Viséan corals from Istanbul are almost unknown, only Erentöz (1966) indicates the occurrence of Syringopora and Siphonodendron.

In the Zonduldak Zone (Zonguldak and Bartın areas, Fig. 1C, D), the Y1lanlı Formation includes all the carbonate rocks of Devonian and Carboniferous age. The Lower Carboniferous succession is exposed almost continuously in the Kokaksu, Gökgöl and Kisla sections (Zonguldak vicinity) and along the discontinuous Topluca and Süzek sec- 
tions (Bartın vicinity). The Y1lanlı Formation consists of variegated limestones, often cherty or silicified and rich in macrofauna.

The Kokaksu section is situated in the riverbed of the Kokaksu Creek, near the Çaydamar hamlet, $2 \mathrm{~km}$ south

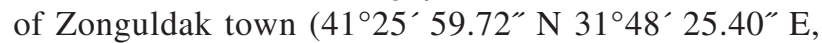
$\mathrm{K}$ in Fig. 1C). Specimens collected by F. Charles in the 1930's came from outcrops destroyed by building works along the creek. The Viséan part of the Y1lanlı Formation is exposed downstream at a small bridge. The lower $30 \mathrm{~m}$ are made of cherty thin-bedded bioclastic and fossiliferous limestone with numerous syringoporids, Dorlodotia briarti and Palaeosmilia murchisoni (Fig. 2). Cherts increase in size and frequence up-section, together with thickness of the limestone beds. The following unit ( $60 \mathrm{~m}$-thick) is the most fossiliferous of the section and includes brachiopods, gastropods, syringoporids and large colonies of Dorlodotia, Ceriodotia and Siphonodendron. The Ceriodotia bartinensis horizon is separated from the $C$. petalaxoides horizon by a $2 \mathrm{~m}$-thick package of dark silicified limestone. These two horizons are repeated by a longitudinal fault. Foraminifers from these units indicate the uppermost Moliniacian (MFZ11B of Hance et al. 2011). The rest of the section is dominated by thick-bedded limestone, usually dark and silicified. The dominant facies are bioclastic packstones and grainstones with abundant brachiopods, gastropods and corals. Large colonies (> $1 \mathrm{~m}$ in diameter) of Siphonodendron are common, together with numerous Palaeosmilia, Aulophyllum and Koninckophyllum. Palastraea konincki (Charles, 1933) is also present. Corals and foraminifers indicate a Warnantian age. The upper part of the section is made of chert beds alternating with siltstone and sandstone belonging to the Alacaağzı Formation (uppermost Viséan to Serpukhovian, Dîl et al. 1976). Both foraminifers and rugose corals indicate the lack of Livian (middle Viséan) deposits while sequence stratigraphy (Denayer, in prep.) confirms this absence.

The Gökgöl section is situated along the road D750 Devrek-Zonguldak, upstream the Asma hamlet, $4 \mathrm{~km}$ south of Zonguldak (41 ${ }^{\circ} 26^{\prime} 19.28^{\prime \prime}$ N-31 ${ }^{\circ} 50^{\prime} 05.43^{\prime \prime} \mathrm{E}$, $\mathrm{G}$ in Fig. 1C). Moliniacian units crop out near the cave entry with facies similar to those observed in the Kokaksu section. Dorlodotia briarti, D. euxinensis, Ceriodotia bartinensis and Siphonodendron ondulosum are abundant. The rest of the succession is exposed nearby in a disused quarry. The Warnantian part of the section is dominated by medium- then thick-bedded grey cherty bioclastic limestone (mainly packstone and grainstone) with an abundant and diversified coral fauna: Siphonodendron, Lithostrotion, Koninckophyllum, Palastraea and syringoporids (Fig. 2). Brachiopods are locally abundant. Foraminifers indicate the late Viséan (MFZ13-14-15?), as do the corals (RC7-8 biozones of Poty et al. 2006). The contact with the Namurian shale is sharp and the facies alternation observed in Kokaksu is not developed here.

The Kisla section is located along a small road, $3 \mathrm{~km}$ SW of Zonguldak ( $41^{\circ} 24^{\prime} 58.01^{\prime \prime} \mathrm{N}-31^{\circ} 43^{\prime} 12.53^{\prime \prime} \mathrm{E}, \mathrm{R}$ in Fig. 1C). The Moliniacian is poorly exposed (some beds with Dorlodotia) while the Warnantian yielded the colonial Siphonodendron, Lithostrotion, Nemistium and Palastraea genera.

In the Bartın area, the Topluca and Süzek sections were sampled. The Topluca section is situated $7 \mathrm{~km}$ northwest of Bartın town, along a new track created between the Topluca earth pit and the valley road (41 $41^{\prime} 15.41^{\prime \prime}$ N-32 $2^{\circ} 7^{\prime} 00.54^{\prime \prime}$ E, T in Fig. 1D). The Viséan part of the Y1lanlı Formation is discontinuously exposed. Moliniacian corals are only known from scree blocks. The Warnantian, exposed in the northern part of the section, is dominated by thick-bedded bioclastic grainstones and rudstones (Fig. 2). The corals are numerous but less diversified than in the previous localities: Siphonodendron species are the only colonial corals, the solitary belonging to Palaeosmilia, Clisiophyllum and Koninckophyllum. The limestone is topped by an erosive disconformity capped by a conglomeratic horizon made of weathered cherts embedded in shale. The latter is overlain by the Alacaağzı Formation siliciclastics.

The Süzek section (Süzek Deresi in Tokay 1954) is situated in the western flank of the valley, $1 \mathrm{~km} \mathrm{NW}$ of Dallica near Bartın (41 ${ }^{\circ} 40^{\prime} 04.72^{\prime \prime} \mathrm{N}-32^{\circ} 18^{\prime}$ 58.19” E, S in Fig. 1D). Strata are inverted. The Moliniacian crops out in the top of the hill and exposes bioclastic facies particularly rich in corals: Dorlodotia, Ceriodotia, Siphonodendron, Lithostrotion, Clisiophyllum, Palaeosmilia, and syringoporids. Warnantian limestones are poorly exposed and its fauna is mainly known from scree and loose blocks near the river. As in the previous section, the limestones are capped by a disconformity upon which lie the Namurian siliciclastics (Fig. 2).

\section{Material and methods}

The newly collected material is housed in the Laboratory of Animal and Human Palaeontology, Department of Geology, University of Liège in Belgium (collection P.ULg). Charles's specimens are housed in the Invertebrates collection in the Royal Belgian Institute of Natural Sciences, Brussels (IRSNB) under numbers IP-10861 and IP-15123. Abbreviations: TS - transverse section, LS - longitudinal section. Localitites: G - Gökgöl, K - Kokaksu, R \& S Kisla, ET - Topluca, SR - Süzek. Authors: M.-E. \& H. Milne-Edwards \& Haime, S.-T.-C. - Semenoff-TianChansky, Y. \& H. - Yabe \& Hayasaka. 


\section{Systematic palaeontology}

Subclass Rugosa Milne-Edwards \& Haime, 1850

Order Stauriida Verrill, 1865

Family Lithostrotionidae d'Orbigny, 1852

Subfamily Lithostrotioninae d'Orbigny, 1852

\section{Genus Siphonodendron McCoy, 1849}

Type species. - Lithodendron pauciradialis McCoy, 1844, Viséan, Ireland.

Diagnosis. - Fasciculate coral with cylindrical corallites. Major septa long, reaching or not the axis. Minor septa developed in the dissepimentarium or entering slightly the tabularium. Axial structure made of a styliform columella bearing rare short septal lamellae. Columella often connected to the counter and/or cardinal septa. Diphymorphic corallites occasionally occur. Cardinal fossula poorly conspicuous. Dissepimentarium made of interseptal dissepiments concentric, V-shaped or herringbone, lacking in small-sized species. Tabulae complete or not, cone-, tent-, bell- or mesa-shaped in diphymorphic specimens. Increase lateral, non-parricidal. Modified from Poty (1981).

Discussion. - The characters of Siphonodendron being simple, they have been recognized in several groups of coral. Unfortunately, all of them were described under the same generic name. Works by Fedorowski (2008), Fedorowski \& Bamber (2007), Jull (1965), Nudds (1979), Poty (1975a, 1981, 1984, 1993, 2010), Scrutton (1983), Semenoff-Tian-Chansky \& Nudds (1979), Rodríguez et al. (2002), Webb (1990, 1994) - among others - showed that at least three distinct stocks of corals evolved in parallel and bear the name and the characters of Siphonodendron. 1) Siphonodendron sensu stricto, common in Eurasia and N Africa. Turkish Siphonodendron belong to this first group. 2) Australian "Siphonodendron" bearing long major septa connected to a strong columella and having differentiated axial and periaxial series of tabellae. They seem to appear earlier than Siphonodendron sensu stricto (late Tournaisian? Webb 1990 - but their age needs to be checked), and their evolution followed different trends (Pickett 1966, Webb 1994). 3) N American "Siphonodendron" having short septa and an inconstant weak columella which is not related to the counter septum (Fedorowski \& Bamber 2007). Their morphological variability is wide (Sando 1965). They appear in the Tournaisian but are not known after the middle part of the Viséan (Sando 1970). A fourth group needs to be cited here: the corals described in the Lower Carboniferous of the Russian Platform by Dobroljubova (1958) under the name Siphonodendron but showing a parricidal increase. They probably belong to the genus Nemistium Thomson \& Nicholson, 1876.

Siphonodendron asiaticum (Yabe \& Hayasaka, 1915) Figure 3A-H

1915 Lithostrotion irregulare var. asiatica Yabe \& Hayasaka; p. 57.

* ?1920 Lithostrotion irregulare var. asiatica Y.\& H. - Yabe \& Hayasaka, pl. 10, fig. 2, pl. 11, fig. 7.

1933 Lithostrotion (S.) irregulare var. asiatica Y. \& H. Yü, p. 95, pl. 29, figs 3, 4, pl. 20, fig. 1.

1933 Lithostrotion aff. irregulare (Phillips). - Charles, p. 138 , pl. IV, fig. 4.3

1937 Lithostrotion irregulare var. asiatica Y. \& H. - Yü, p. 95 , pl. 29, figs 3,4 , pl. 20 , fig. 1 .

1958 Lithostrotion junceum (Fleming). - Ünsalaner-Kiragli, p. 57, pl. 12, fig. 1.

1960 Lithostrotion asiatica Y. \& H. - Vassiljuk, p. 79, pl. 19, fig. 2. [cum syn.]

1962 Lithostrotion irregulare var. asiatica Y. \& H. - Yü et al., p. 73 , pl. 21, fig. 2.

1976 Siphonodendron ex. gr. irregulare (Phillips). - Dîl et al., p. 408, pl. I, fig. 2

1978 Lithostrotion irregulare var. asiatica Y. \& H. - Fan, p. 168 , pl. 64 , fig. 7.

1989 Lithostrotion irregulare var. asiatica Y. \& H. - Wu \& Zhao, p. 106, pl. 24, fig. 1.

non 2003 Lithostrotion irregulare asiatica Y. \& H. - Fan et al., p. 321 , pl. 40 , fig. 2 .

Holotype. - Yabe \& Hayasaka (1915) did not appoint any holotype, no lectotype was chosen and the systematic position (species, subspecies and variety coexist in the literature) was never precisely established. Vassiljuk's (1960) opinion to consider asiaticum as a valid species is followed here.

Material. - 20 colonies: 3 from Kokaksu section, 6 from Gökgöl, 6 from Süzek, 3 from Topluca and 2 from Amasra (Ralli's collection).

Diagnosis. - Phaceloid Siphonodendron with small corallite having a mean diameter of $2.9 \mathrm{~mm}$ and 16 septa of both orders. Major septa usually connected to the columella. Minor septa half as long as the major. Dissepimentarium composed of one single row of interseptal dissepiments. After Yabe \& Hayasaka (1915) and Fan et al. (2003).

Description. - Several colonies, observed in the Kokaksu section, reach 50 to $60 \mathrm{~cm}$ in diameter and height. They are mainly phaceloid with supporting processes, 


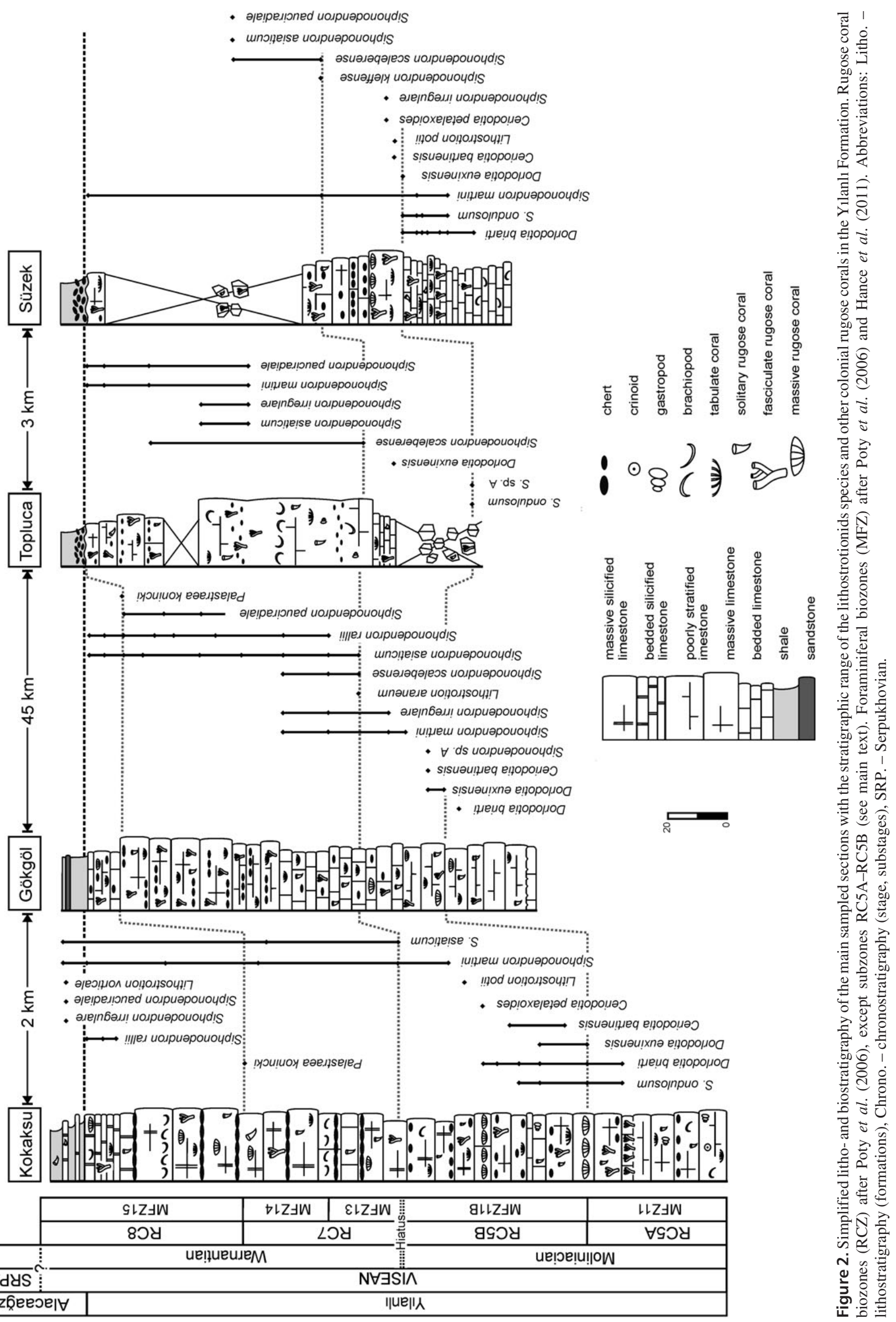


but some colonies show a subcerioid trend and prismatic corallites (Fig. $3 \mathrm{H})$. The corallites are cylindrical their external wall bears septal grooves and ridges (Fig. 3A). Transverse section: The mature corallites have a mean diameter of $2.9 \mathrm{~mm}$ (maximum $4 \mathrm{~mm}$ ) and possess 16 septa of both orders (maximum 20, Fig. 4). The major septa are long and usually connected to the columella or withdrawn from the axis and create a free zone up to $1.5 \mathrm{~mm}$ large in the centre of the tabularium. Minor septa are $1 / 3$ to $1 / 2$ as long as the major and commonly enter into the tabularium. They are reduced to septal crests on the external wall in some specimens. The columella is $0.75-1 \mathrm{~mm}$ long, often thickened (up to $0.5 \mathrm{~mm}$ ) and bears short spiny septal lamellae confluent with the major septa. The columella is commonly connected to the counter septum, rarely to the cardinal one. Diphymorphic corallites are frequent (Fig. 3C). The cardinal fossula is seldomly conspicuous. The dissepimentarium comprises only one row of small interseptal dissepiments, less than 1 corallite in 100 shows an incomplete second row. The external wall is straight but thick (up to $0.25 \mathrm{~mm}$ ). Longitudinal section: The tabulae are complete, upturned towards the columella (Fig. $3 \mathrm{Fb}-\mathrm{c}$ ), horizontal and complete in diphymorphic corallites. The dissepiments are small, $0.2 \mathrm{~mm}$ long and $0.4 \mathrm{~mm}$ high, arranged in vertical rows. There are on average 20 tabulae and 30-40 dissepiments per centimetre height.

Discussion. - Morphological characters of Siphonodendron asiaticum are similar to those of Siphonodendron junceum (Fleming, 1828) but the occurrence of a single row of dissepiments allows an easy distinction of the two species, the dissepimentarium is lacking in the latter. The radial pattern of septa and their confluence with the columella is very similar to that observed in S. junceum. Nevertheless, the small spiny septal lamellae attached to the columella (Fig. 3Fe) - a common character of large species of the genus - is not observed within S. junceum. S. asiaticum differs from $S$. pauciradiale by smaller dimension and a lower number of septa.

Occurrence. - In China, the species is known in the late Viséan of Guangzi and Anhuei Province (Yü 1933) as well as in Hunan and Yunnan (Yabe \& Hayasaka 1915). In the Donets Basin (Vassiljuk 1960), S. asiaticum is known in $\mathrm{C}^{\mathrm{V}}{ }_{1 \mathrm{f}}$, horizon (late Viséan). Up to now, the species has been de- scribed neither in W Europe nor in N Africa. S. asiaticum is abundant in Bartın and Zonguldak area, in the Warnantian (MFZ13-MFZ14 foraminiferal biozones of Poty et al. 2006).

\section{Siphonodendron pauciradiale (McCoy, 1844)}

Figure 3I-K

*1844 Lithodendron pauciradialis McCoy; p. 189, pl. 27, fig. 7.

2005 Siphonodendron pauciradiale (McCoy). - Aretz \& Nudds, p. 176. [cum syn.]

2005 Siphonodendron pauciradiale (McCoy). - Cózar et al., p. 38, figs 10, 12 .

2007 Siphonodendron pauciradiale (McCoy). - Rodríguez \& Somerville, p. 278, pl. 1, fig. 8.

2009 Siphonodendron pauciradiale (McCoy). - Rodríguez \& Said, p. 10, pl. 1, figs 3-4.

2010 Siphonodendron pauciradiale (McCoy). - Aretz, p. 32 , fig. 5e.

2010 Siphonodendron pauciradiale (McCoy). - Aretz \& Herbig, p. 302, fig. 6b.

2011 Siphonodendron pauciradiale (McCoy). - Denayer et al., p. 171, pl. 10, fig. F.

2012 Siphonodendron pauciradiale (McCoy). - Denayer; p. 324, fig. 7E.

2012 Siphonodendron pauciradiale (McCoy). - Lin et al., p. 334, pl. 2, figs I-K, pl. 3, figs A, B.

2012 Siphonodendron pauciradiale (McCoy). - Somerville et al., p. 311, fig. 3A.

2013 Siphonodendron pauciradiale (McCoy). - Said et al., p. 374 , fig. $5 \mathrm{H}$.

Lectotype. - Specimen 82-1925, Glencar Limestone (Asbian), Magheramore, Tobercurry, County Sligo, Ireland; Griffith Collection, National Museum of Ireland, Dublin.

Material. - 13 fragments of colonies: 5 from Gökgöl section, 2 from Kokaksu, 1 from Amasra (coll. Ralli), 4 from Topluca and 1 from Süzek.

Diagnosis. - Dendroid or phaceloid Siphonodendron. Corallites $4 \mathrm{~mm}$ in diameter, having 18-20 septa of both orders. One or two rows of interseptal dissepiments, rarely up to 4. After Poty (1981).

Figure 3. A-H - Siphonodendron asiaticum (Yabe \& Hayasaka, 1915). • A - specimen SR.7.14 from Süzek section, external view (× 2); B - K.12.2 from Kokaksu, TS in an offsetting corallite $(\times 6)$; C - ET.2.5 from Topluca, TS in an offsetting corallite $(\times 6)$; D - ET.2.5b from Topluca, TS in an offsetting corallite $(\times 6)$; E - ET.2.2 from Topluca, TS $(\times 3)$; F - K.9.1 from Topluca, Fa - TS $(\times 3), \mathrm{Fb}-\mathrm{LS}(\times 3)$, Fc - closer view of LS $(\times 6)$; G - ET.2.5 from Topluca, TS (× 3); H - G.5.4 from Gökgöl, TS (× 3). • I-K - Siphonodendron pauciradiale (McCoy, 1849). • I - SR.7.1 from Süzek, Ia - TS (× 6), $\mathrm{Ib}-\mathrm{TS}(\times 3)$; J - ET.1.5 from Topluca, TS (×3); K - G.16.3 from Gökgöl, LS (×3). All specimens are Warnantian (Late Viséan). Scale bar equals 7.5 mm for A, $5 \mathrm{~mm}$ for E, Fa, Fb, G, H, J, K and $2.5 \mathrm{~mm}$ for B-D, Fc-Fe, Ia. 


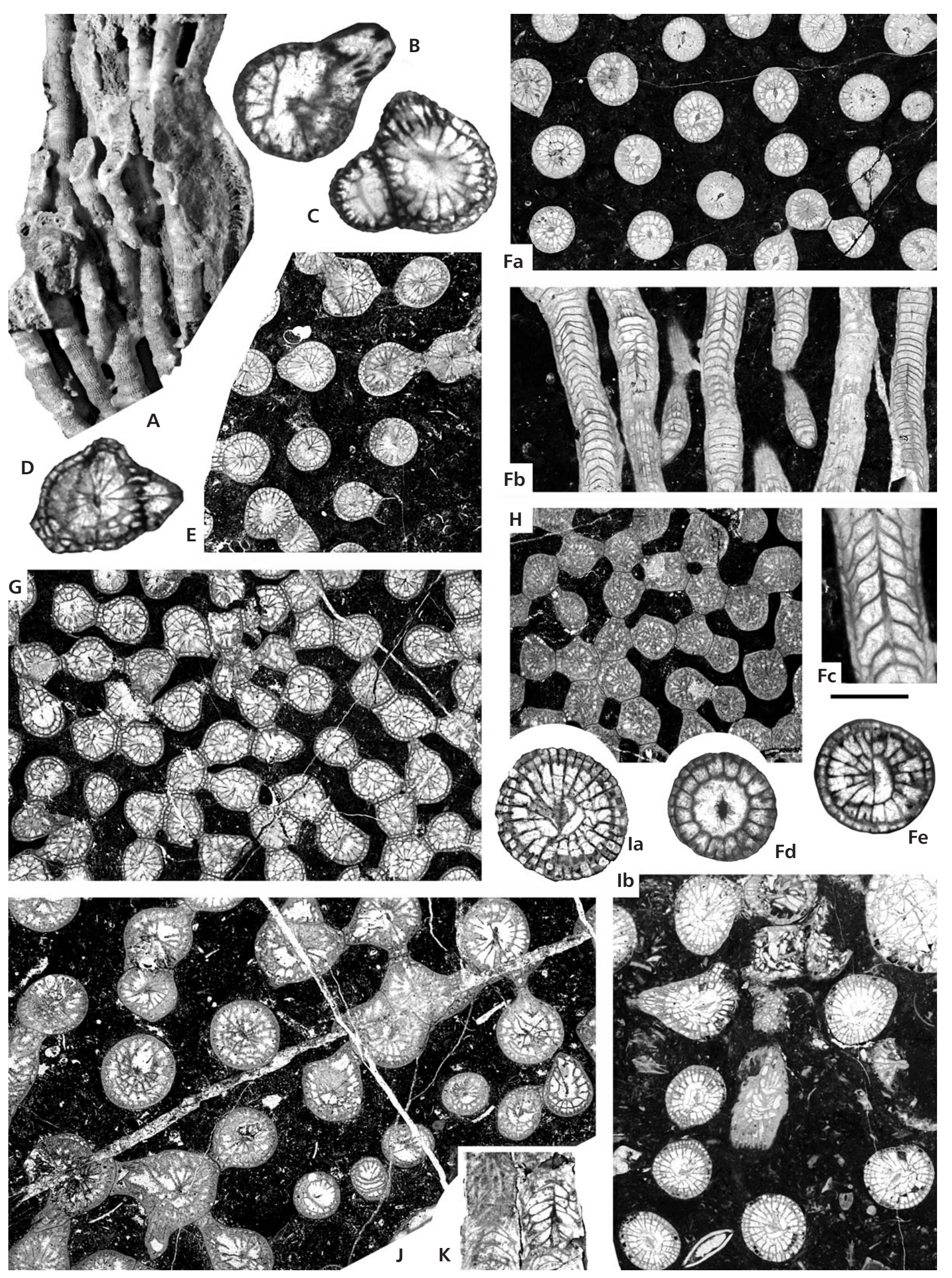




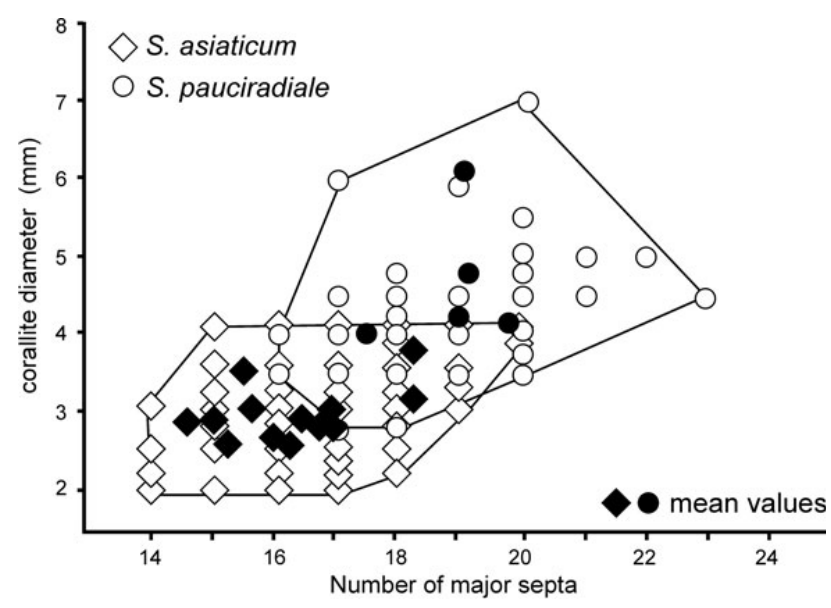

Figure 4. Scatter diagram showing the number of major septa plotted against corallite diameter for Siphonodendron asiaticum (Yabe \& Hayasaka, 1915) and Siphonodendron pauciradiale (McCoy, 1849), based on 280 and 40 measurements, respectively. The mean values are given for each colony.

Description. - Transverse section: The corallites have a mean diameter of $4.3 \mathrm{~mm}$ (maximum $7 \mathrm{~mm}$, Fig. 4). The mean tabularium diameter is $3.7 \mathrm{~mm}$ (maximum $4.5 \mathrm{~mm}$ ). There are 19 septa of both orders on average (maximum 24). The latter are thick and measure $1 / 3$ to $1 / 4$ of the corallite radius. The cardinal septum is often shorter. The minor septa are restricted to the dissepimentarium. The columella is $0.8-1 \mathrm{~mm}$ long, usually thickened with a rounded section. Some rare thin septal lamellae are sometimes present. In the juvenile stages, the columella is connected to the counter septum and/or to the axial ends of other major septa. In mature stages, the septa usually withdraw from the axis. Diphymorphic corallites are occasional. The dissepimentarium comprises one complete row of dissepiments or rarely a second incomplete one. The external wall is $0.5-0.8 \mathrm{~mm}$ thick and regular. Longitudinal section: The tabulae are almost always complete, upturned towards the columella, concave up in the periphery, forming a peripheral gutter. The dissepiments are small (0.2 mm large, $0.4-0.6 \mathrm{~mm}$ long), inclined at $75-80^{\circ}$ towards the tabularium. There are 18-20 tabulae and 25-30 dissepiments per centimetre height.

Discussion. - All specimens fit perfectly with the definition of $S$. pauciradiale. One colony from the Topluca section (Fig. 3J) shows small-sized S. asiaticum-like corallites in its peripheral zone (see $S$. asiaticum and $S$. irregulare for comparison).

Occurrence. $-S$. pauciradiale is relatively common in the Warnantian of W Europe (Poty 1981) and N Africa (Aretz 2010) where it marks the base of the RC7 zone of Poty et al. (2006). The species occurs in the uppermost Viséan and Serpukhovian of SE China (Lin et al. 2012) and in the lower Warnantian of S Turkey (Anatolides: Denayer 2012). In NW Turkey, it is only known in the lower Warnantian RC7 $\beta$ coral biozone and MFZ14 foraminiferal biozone of Poty et al. (2006).

\section{Siphonodendron sp. A}

Figure 5E, F

?1976 Lithostrotion rossicum Stuckenberg. - Onoprienko, p. 11, pl. 3, figs 1, 2 .

Material. - Two fragments of colonies from the Gökgöl and Topluca sections.

Description. - Transverse section: Small-sized Siphonodendron with corallites $6 \mathrm{~mm}$ large (maximum $7 \mathrm{~mm}$, Fig. 6) and $4.5 \mathrm{~mm}$ (maximum $6 \mathrm{~mm}$ ) of tabularium diameter. There are 27 septa of both orders (maximum 29). The major septa are $3 \mathrm{~mm}$ long; the minor septa are $1-1.5 \mathrm{~mm}$ long. All the septa are thin and straight. The cardinal septum is longer and connected to the columella. The cardinal fossula is conspicuous. The axial plate is $1-1.2 \mathrm{~mm}$ long and bears 6-12 septal lamellae which are irregular, bifid and sometimes longer than the axial plate, producing a star-shaped columella (Fig. 5Ec, F). Some of the lamellae are confluent with the axial ends of the septa while others are withdrawn and have a sharp or rounded end. The dissepimentarium contains 4-5 rows of interseptal dissepiments, two of them are concentric, and the others are $\mathrm{V}$-shaped or herringbone. The external wall is thin and straight. Longitudinal section: The tabulae are incomplete, steeply upturned towards the columella, tent- or bell-shaped in the axial part and declined towards the periphery. The dissepiments are small (less than $1 \mathrm{~mm}$ long and high) and inclined at $40-50^{\circ}$ towards the tabularium. There are 16 tabulae and 20 dissepiments per centimetre height. The axial structure appears as an irregularly thick

Figure 5. A, B - Siphonodendron rallii sp. nov. (Warnantian-Late Viséan); A - specimen G.5.10 from Gökgöl, Aa: TS in a colony (× 3), Ab, Ac - close-up views of the columella, TS $(\times 10)$; B - G.16.6 (holotype) from Gökgöl, Ba - TS $(\times 3)$, Bb - LS $(\times 3)$, Bc - TS $(\times 6)$. - C, D - Siphonodendron irregulare (Phillips, 1836) (Warnantian-Late Viséan); C - K.12.1 from Kokaksu, Ca - TS $(\times 3)$, Cb - LS $(\times 3)$, Cc - TS $(\times 6)$; D - SR.7.15, TS (× 3).・E, F - Siphonodendron sp. A. (Moliniacian-Early Viséan); E - G.2.1 from Gökgöl, Ea - TS (× 3), Eb - LS (×6), Ec - close-up view of the columella, TS (× 10); F - ET.4.2 from Topluca, TS (×6). Scale bar equals $5 \mathrm{~mm}$ for A, Ba, Bb, Ca, Cb, D, Ea, $2.5 \mathrm{~mm}$ for Bc, Cc, Eb, F, 1.5 $\mathrm{mm}$ for $\mathrm{Ab}, \mathrm{Ac}$ and $\mathrm{Ec}$. 
Julien Denayer • Viséan Lithostrotionidae (Rugosa) from NW Turkey
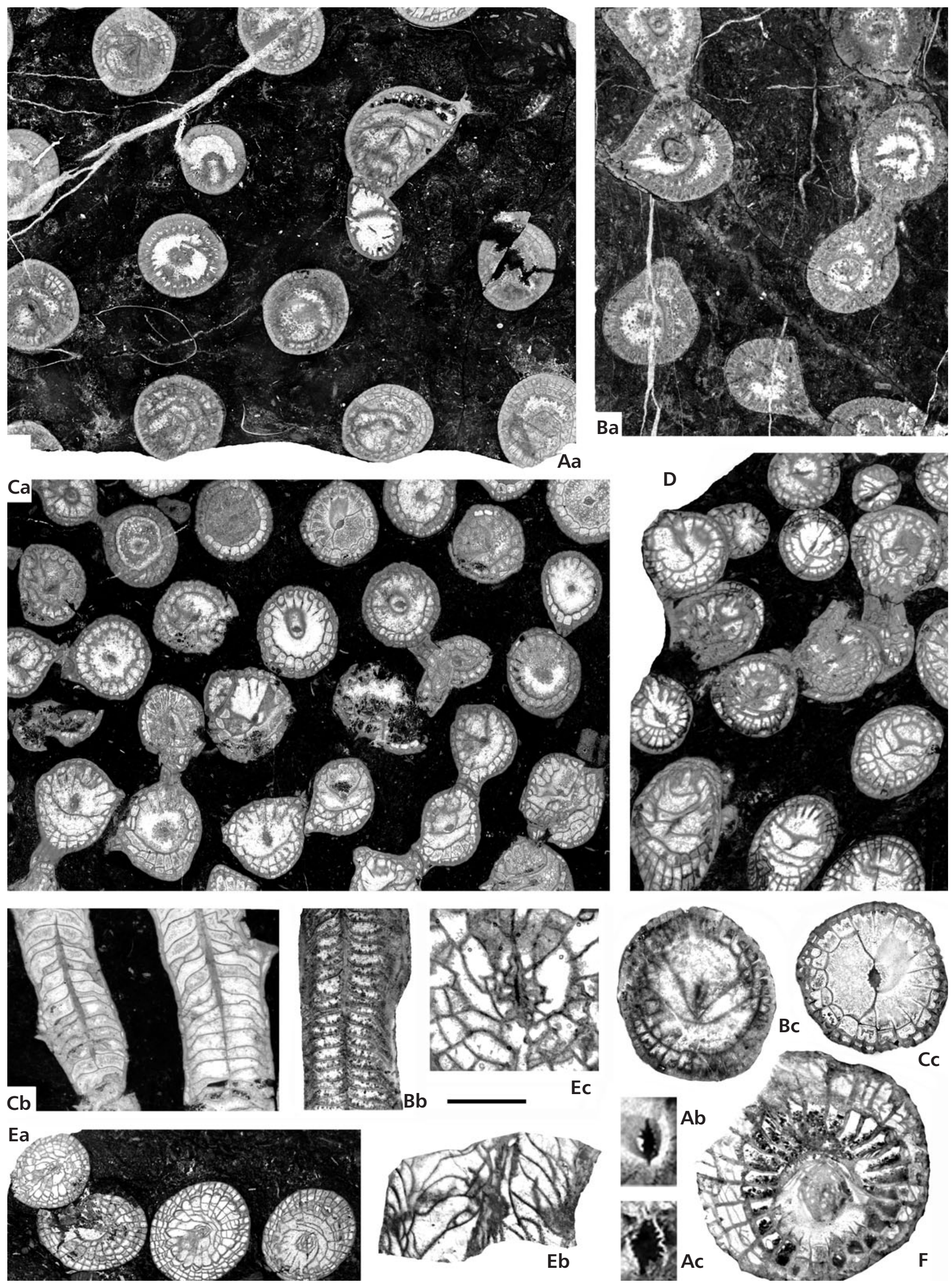


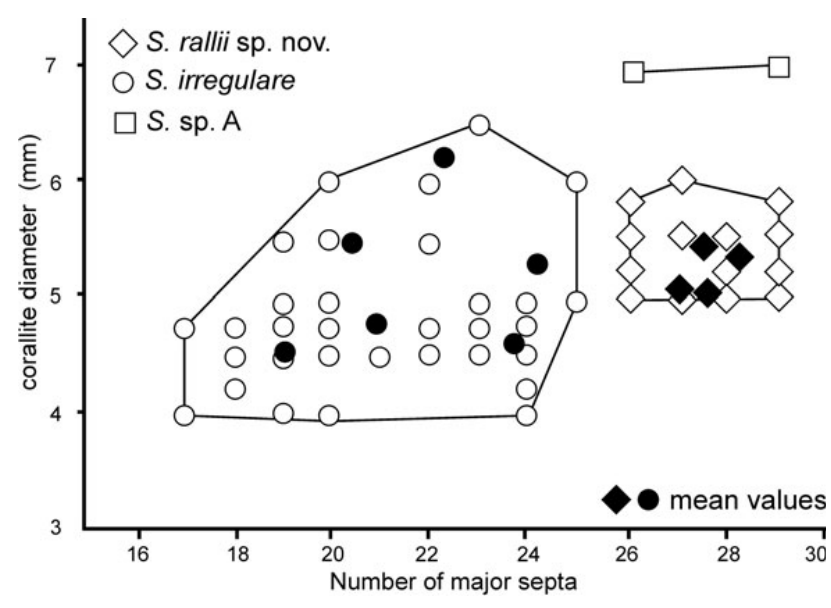

Figure 6. Scatter diagram showing the number of major septa plotted against corallite diameter for Siphonodendron irregulare (Phillips, 1836), Siphonodendron rallii sp. nov. and Siphonodendron sp. A, based on 56, 24 and 5 measurements, respectively. The mean values are given for each colony.

lath, irregularities being due to the irregular septal lamellae (Fig. 5Eb).

Discussion. - These small colonies belong to an as yet undescribed species sharing with S. irregulare (Phillips, 1836) and $S$. intermedium Poty, 1981, a similar diameter and number of septa. However $S$. sp. A differs from the latter by a wider dissepimentarium and withdrawn septa. The peculiar star-shaped axial structure is a specific character of large Siphonodendron species but not common in small-sized species. S. aff. intermedium from the Holkerain of Cumbria, figure by Poty (1993, figure 7:5) also shows a similar diameter but its septa are less numerous and longer than in the present species, however it shows occasionally a similar columella. Onoprienko (1976) described similar forms with short minor septa under the name Lithostrotion rossicum Stuckenberg 1904 in early Viséan strata of the Omolon Massif (E Siberia). As S. rossicum Stuckenberg 1904 has been synonymised with $S$. pauciradiale (McCoy, 1844) by Hill (1938-1941), this species should be renamed. Supplementary material from NW Turkey or Omolon is needed for an accurate description.

Occurrence. $-S$. sp. A is known in the lower Viséan in the Omolon, where it is accompagnied by $S$. ondulosum and Palaeosmilia murchisoni. The Turkish specimens are from time-equivalent strata dated as the upper Moliniacian by foraminifers (MFZ11B of Hance et al. 2011).

\section{Siphonodendron irregulare (Phillips, 1836)} Figure 5C, D

*1836 Lithodendron irregulare Phillips; p. 202, pl. 2, figs $14,15$.
?1958 Lithostrotion rossicum Stuckenberg. - Dobroljubova, p. 151, pl. 21, figs 1-5.

?1958 Lithostrotion volkovae Dobroljubova; p. 153, pl. 22, figs $1,2$.

1960 Lithostrotion irregulare Phillips. - Vassiljuk, p. 83, pl. 21, figs 1-1c.

1966 Lithostrotion irregulare Phillips. - Bykova, p. 132, pl. 21, figs 1, 2 .

1966 Lithostrotion volkovae Bykova; p. 134, pl. 21, figs 6, 7.

1977 Lithostrotion (Siphonodendron) volkovae Dobroljubova. - Khoa, p. 333, pl. 5, figs 3, 4.

non 1989 Siphonodendron irregulare (Phillips). - Wu \& Zhao, p. 106, pl. 25, figs 2,5 .

2002 Siphonodendron irregulare (Phillips). - Aretz, p. 112 , pl. 5, fig. 4, pl. 11, fig. 4. [cum syn.]

non 2002 Siphonodendron cf. irregulare (Phillips). - Aretz, p. 193, figs $61,2$.

2005 Siphonodendron sp. - Aretz \& Nudds, p. 178, pl. 3, fig. 1.

2010 Siphonodendron irregulare (Phillips). - Aretz \& Herbig, p. 302, fig. 6C.

2011 Siphonodendron irregulare (Phillips). - Denayer et al., p. 170, pl. 7, fig. N.

2012 Siphonodendron irregulare (Phillips). - Denayer, p. 324 , fig. $7 \mathrm{G}$.

Holotype. - Phillips' types are lost and no lectotype has been chosen (Poty 1981). Nevertheless, topotypes from Phillips' locality (Ashfell, Cumbria) were described and figured by Poty (1993).

Material. - 7 fragments of colonies: 2 from Gökgöl section, 3 from Kokaksu, 1 from Süzek and 1 from Topluca.

Diagnosis. - Dendroid to phaceloid Siphonodendron. Corallites with a mean diameter of 4.5-6 $\mathrm{mm}$ having 20-24 septa of both orders (maximum 26). Dissepimentarium comprising 1-4 rows of interseptal dissepiments. After Poty (1993).

Description. - Transverse section: The corallites have a mean diameter of $4.9 \mathrm{~mm}$ (maximum $7 \mathrm{~mm}$, Fig. 6). The tabularium is $3.8-4 \mathrm{~mm}$ large. There are 19-21 septa of both orders (maximum $25 \mathrm{~mm}$ ). The major septa are thin, except for the cardinal one, which is usually dilated and connected to the columella. The minor septa are restricted to the dissepimentarium but can extend into the tabularium. The columella varies from a $0.8-1 \mathrm{~mm}$ long axial plate to a spiny structure up to $1 \mathrm{~mm}$ thick. The dissepimentarium comprises one complete row of interseptal dissepiments, rarely a second incomplete one. In juvenile specimens, the dissepimentarium can be reduced or absent. Longitudinal section: The tabulae are complete, tent- or 
bell-shaped, upturned towards the columella and declined laterally, forming a shallow peripheral gutter. The dissepiments are small (0.2 mm long, $0.4 \mathrm{~mm}$ high) and almost vertically disposed. There are 14-18 tabulae and 30-32 dissepiments per centimetre height.

Discussion. - The dimensions and number of septa of the Turkish materials are those of $S$. irregulare (Phillips, 1836). The specimens have a similar narrow dissepimentarium. $S$. irregulare differs from $S$. pauciradiale by a larger diameter, greater number of septa and a narrower dissepimentarium. The species shares the dimensions of S. rallii sp. nov. but the latter has more septa.

Occurrence. $-S$. irregulare is known from the basal Livian to the upper Warnantian in Belgium and British Isles (Hill 1938-1941, Poty 1981, Aretz \& Nudds 2005), in the upper Viséan of N Africa (Aretz 2010), SW Spain (Rodríguez et al. 2002) and S France (Aretz 2002). Its occurrence in NW China needs to be checked (Lin \& Rodríguez 1993). In NW Turkey, S. irregulare occurs with $S$. asiaticum in the lower Warnantian (RC7 $\beta$ coral zone of Poty et al. 2006). The species is also present in the lower Warnantian in S Turkey (Anatolides: Denayer 2012).

\section{Siphonodendron rallii sp. nov.}

\section{Figures 5A, B, 7A}

Etymology. - This new species is dedicated to G. Ralli, pioneer in the study of the Carboniferous in Zonguldak and Bartın.

Holotype. - Colony G.16.6 - Zonguldak 2011 (3 TS, 1 LS).

Type horizon and locality. - Massive cherty limestone forming the upper unit of the Ylanlı Formation, Warnantian. Gökgöl section, 4 km SE of Zonguldak, NW Turkey.

Material. - 10 colonies: 4 from Kokaksu and 6 from Gökgöl.

Diagnosis. - Siphonodendron with corallites $5.5 \mathrm{~mm}$ in diameter and 27 septa of both orders. Tabularium wide, central area free of septa. Major septa short. Columella simple, usually thick and rarely connected to the septa. Tabulae complete, mesa-shaped with only axial ends upturned towards the columella.

Description. - Transverse section: The corallites have a mean diameter of $5.5 \mathrm{~mm}$ (maximum $6 \mathrm{~mm}$, Fig. 6) with a wide tabularium reaching $5.2 \mathrm{~mm}$ in diameter. There are 27 septa of both orders on average (maximum 29). They are short, typically withdrawn towards the dissepimenta- rium, amplexoid in some cases. The minor septa are short. Both major and minor septa have an inflated base, with a cuneiform profile. The columella is $1.5 \mathrm{~mm}$ long, 0.3-0.4 mm wide and bears 5-10 short septal lamellae (Fig. 5Ab, c). The columella is rarely connected to the counter septum. The cardinal fossula is inconspicuous. The dissepimentarium comprises 1-2 rows of interseptal dissepiments, in rare cases, an incomplete third row appears. The external wall is thick $(0.5-0.8 \mathrm{~mm})$ and regular. Longitudinal section: The tabulae are complete, flat or mesa-shaped with only their axial parts upturned towards the columella (Fig. 5Bb). They are flat or mesa-shaped where the columella is absent. The dissepiments are $0.3 \mathrm{~mm}$ long and $0.8 \mathrm{~mm}$ high and inclined at $80^{\circ}$ towards the tabularium. There are 12-18 tabulae and about 15 dissepiments per centimetre height.

Discussion. - The characters of these specimens do not fit with any described Siphonodendron species. Their size is equivalent to that of $S$. irregulare (Phillips, 1836) or $S$. intermedium (Poty, 1981) but they have a number of septa equivalent to $S$. martini (Milne-Edwards \& Haime, 1851). The reduced length of the septa is usually not a specific character but in this material, all the specimens show short major and minor septa. The particularly flat or mesa-shaped tabulae with only their axial ends upturned towards the axis are uncommon in Siphonodendron sensu stricto but are usual within the N American "Siphonodendron". Siphonodendron with similar dimensions were figured - but not described by Rodríguez \& Falces (1992) from the upper Viséan of SW Spain. Siphonodendron curvatum (Yü, 1933) from SE China possesses the same number of septa but is quite larger and has longer septa. Corals attributed to Lithostrotion curvatum by Vassiljuk (1960) have similar dimensions but have also longer septa. S. tindoufense and S. ouarkziense Rodríguez \& Somerville in Rodríguez et al., 2013 from the Lower Bashkirian of Morocco are both characterized by flat tabulae. S. tindoufense is smaller (3-5.5 mm) than S. rallii. S. ouarkense has similar dimensions and number of septa but its septa extend to the internal part of the tabularium. S. nigmadnovi (Ogar, 2008) from the Lower Viséan of Tien Shan show a similar tabularium and short septa but is characterized by a dissepimentarium commonly lacking. The strikingly short septa and wide tabularium of the Turkish materials are features commonly met in North American "Siphonodendron". "S." oculinum Sando, 1963 shows such characters, together with similar diameter and number of septa (4.5-6 mm in diameter for 22-26 septa). The Turkish specimens share with the American corals a columella disconnected from the counter septum (less than $5 \%$ of the studied corallites show a long counter septum connected to the columella) and mesa-shaped tabulae. However, this new species differs from the American one by a more complex axial structure (thicker, bearing septal lamellae). If 
a likeness between the $S$. rallii and "S." oculinum is clear, it has to be included in the genus Siphonodendron sensu stricto as its axial structure is typical of the Eurasian genus. Moreover, $S$. rallii corallites are very similar to some $S$. martini specimens having a narrow dissepimentarium and a simple columella. $S$. rallii has possibly evolved from $S$. martini by progenesis: the descendant $(S$. rallii) is smaller than its ancestor (S. martini), but its number of septa has almost not decreased while its morphological characters (dissepimentarium, columella) are simpler. The stratigraphic succession of the two species is compatible with this view. The observation of S. martini in anearly stage of development is necessary to confirm this interpretation.

Occurrence. $-S$. rallii is common in the massive cherty limestone of the Y1lanlı Formation at Kokaksu and Gökgöl. Associated coral taxa are $S$. scaleberense and S. asiaticum indicating the $\mathrm{RC} 7$ and $\mathrm{RC} 8$ biozones while the foraminifers indicate the MFZ13-MFZ14 (Warnantian) zones of Poty et al. (2006). Up to now, S. rallii is not known outside the type area.

\section{Siphonodendron martini (Milne-Edwards \& Haime, 1851)}

Figure 7B-D

*1851 Lithostrotion martini Milne-Edwards \& Haime; p. 436.

?1958 Lithostrotion caespitosum Martin. - Dobroljubova, p. 155, pl. 22, fig. 3, pl. 23, figs 1-3.

p.p. 1960 Lithostrotion caespitosum Martin. - Vassiljuk, p. 85, pl. 21, fig. 3.

p.p. 1960 Lithostrotion curvaturum Yü. - Vassiljuk, pl. 21, figs 2, 2a.

1966 Lithostrotion caespitosum Martin. - Bykova, p. 135, pl. 21, figs 3, 4 .

1975 Siphonodendron fraiponti Charles. - Poty, p. 78, pl. 2, figs 4, 5, pl. 3, figs 3-8.

2005 Siphonodendron martini (M.-E. \& H.). - Aretz \& Nudds, p. 178, pl. 3, fig. 2. [cum syn.]

2009 Siphonodendron martini (M.-E. \& H.). - Rodríguez \& Said, p. 10, pl. 1, figs 1, 2.

2010 Siphonodendron martini (M.-E. \& H.). - Aretz, p. 334, fig. 5h.

2011 Siphonodendron martini (M.-E. \& H.). - Aretz, p. 611 , fig. $9 \mathrm{E}$.
2011 Siphonodendron martini (M.-E. \& H.). - Denayer et al., p. 171, pl. 6, fig. K.

2012 Siphonodendron martini (M.-E. \& H.). - Somerville et al., p. 311, fig. 3B.

2013 Siphonodendron martini (M.-E. \& H.). - Said et al., p. 375 , fig. $6 \mathrm{~B}$.

Lectotype. - Chosen by Semenoff-Tian-Chansky \& Nudds (1979): specimen E 1446, Lower Carboniferous, Yorkshire; Collection Phillips, University Museum of Oxford, figured by Milne-Edwards \& Haime (1851).

Material. -19 colonies and fragments: 6 from the Kokaksu section, 3 from Gökgöl, 2 from Amasra (coll. Ralli), 3 from Topluca and 5 from Süzek.

Diagnosis. - Phaceloid Siphonodendron with corallites 6-10 mm in mean diameter, having 23-25 septa of both orders and 2-4 rows of interseptal dissepiments. After Semenoff-Tian-Chansky \& Nudds (1979).

Description. - Transverse section: The corallites with a mean diameter of $7.3 \mathrm{~mm}$ (maximum $9 \mathrm{~mm}$, Fig. 8). The tabularium is on average $6.3 \mathrm{~mm}$ in diameter. There are 25 septa of both orders (maximum 29). They are long (up to $1 / 3$ of the corallite radius), straight and few of them reach the columella. The minor septa are half as long as the major and they enter slightly into the tabularium. The columella is $1.5-2 \mathrm{~mm}$ long, $0.3-0.4 \mathrm{~mm}$ thick and bears some rare septal lamellae. The cardinal fossula is inconspicuous except in some diphymorphic corallites (Fig. 7Da). The dissepimentarium comprises 2-3 - rarely 4 - rows of interseptal dissepiments. Some lonsdaleoid dissepiments occur in large-sized specimens with connecting processes. The external wall is $0.25 \mathrm{~mm}$ thick and regular. Longitudinal section: The tabulae are mainly complete but some declined peri-axial tabellae were noticed. In diphymorphic corallites, the tabulae are complete and mesa-shaped (Fig. 7Db). The dissepiments are $0.3 \mathrm{~mm}$ long and $0.7 \mathrm{~mm}$ high and declined towards the tabularium at an angle varying between $50^{\circ}$ and $80^{\circ}$. There are $18-20$ tabulae and 20-24 dissepiments per centimetre height.

Variability. - More than the dimensions and number of septa of the corallites, the variability affects the dissepimentarium width and the vertical continuity of the columella. Nevertheless, diphymorphic and columellate colonies are found in the

Figure 7. A - Siphonodendron rallii sp. nov., specimen G.16.6 (holotype) from Gökgöl, TS (×3)・ B-D - Siphonodendron martini (Milne-Edwards \& Haime, 1851); B - G.15.1 from Gökgöl, TS (× 3); C - K.11.1 from Kokaksu, Ca: TS (× 3), Cb: LS (× 3); D - ET.2.4 from Topluca, Da - TS showing diphymorphic corallites $(\times 3), \mathrm{Db}-\mathrm{LS}(\times 3) \cdot \bullet \mathrm{E}-\mathrm{H}$ - Siphonodendron scaleberense Nudds \& Somerville, 1987; E - KR.3.b.1 from Kokaksu (loose block), TS (× 3); F - G.2.5 from Gökgöl, TS (×3); G -SR.6.30 from Süzek, TS $(\times 3)$; H - ET.3.6 from Süzek, LS $(\times 3)$. $・$ I - Siphonodendron kleffense (Schindewolf, 1928), SR.6.2 from Süzek, TS (× 3). All the specimens are Warnantian (Late Viséan). Scale bar equals 5 mm for all. 

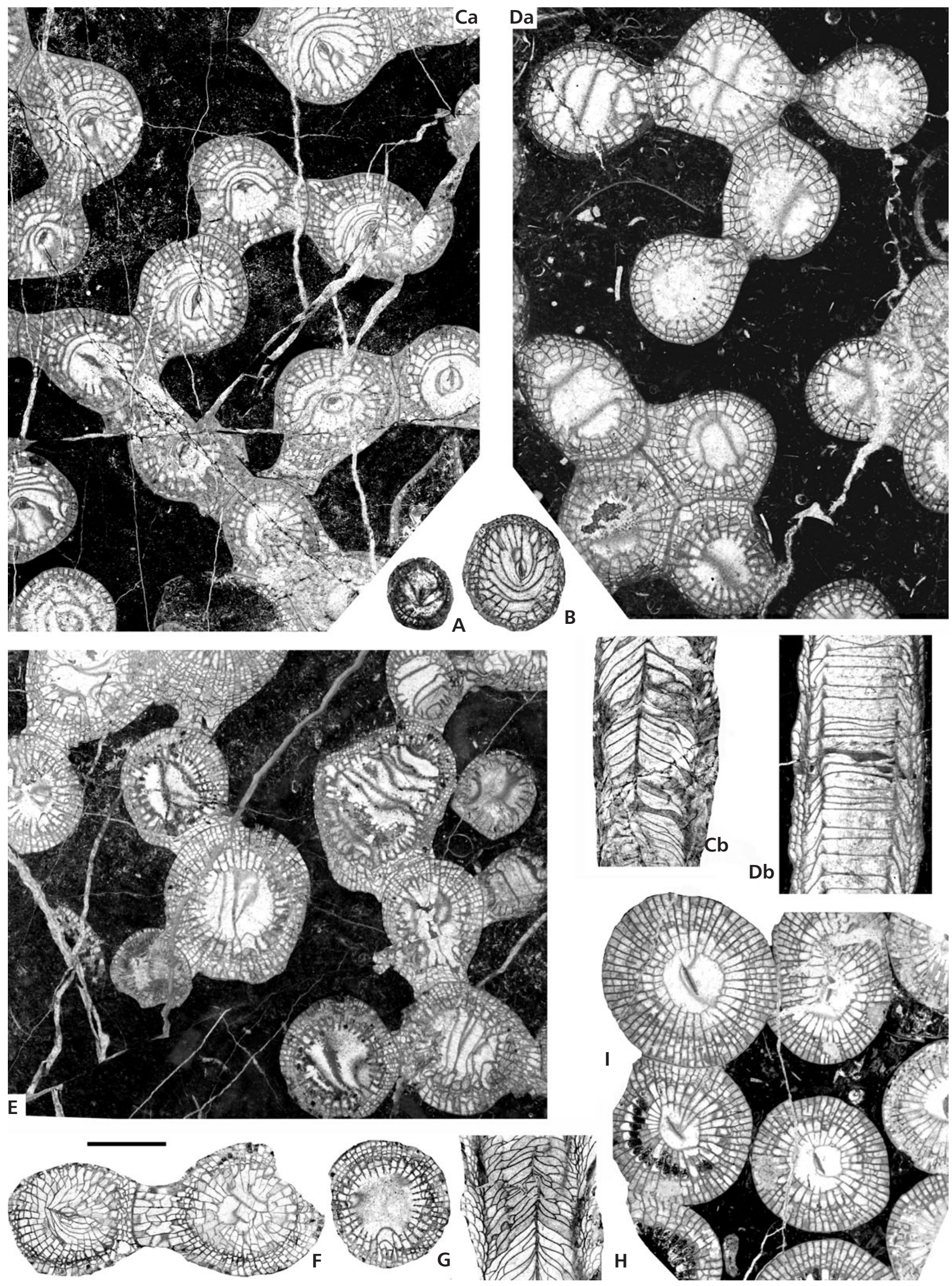


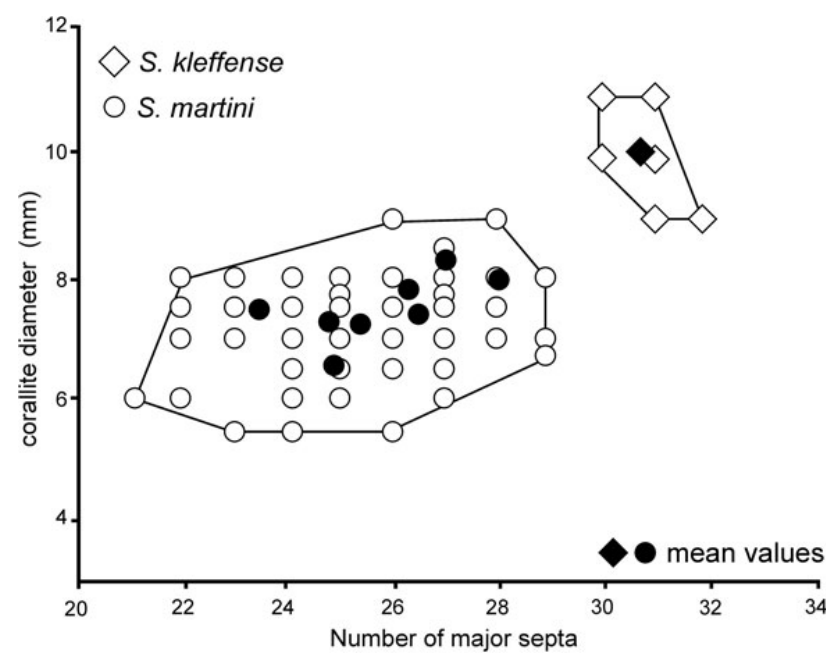

Figure 8. Scatter diagram showing the number of major septa plotted against corallite diameter for Siphonodendron martini (Milne-Edwards \& Haime, 1851) and Siphonodendron kleffense (Schindewolf, 1928), based on 88 and 8 measurements, respectively. The mean values are given for each colony.

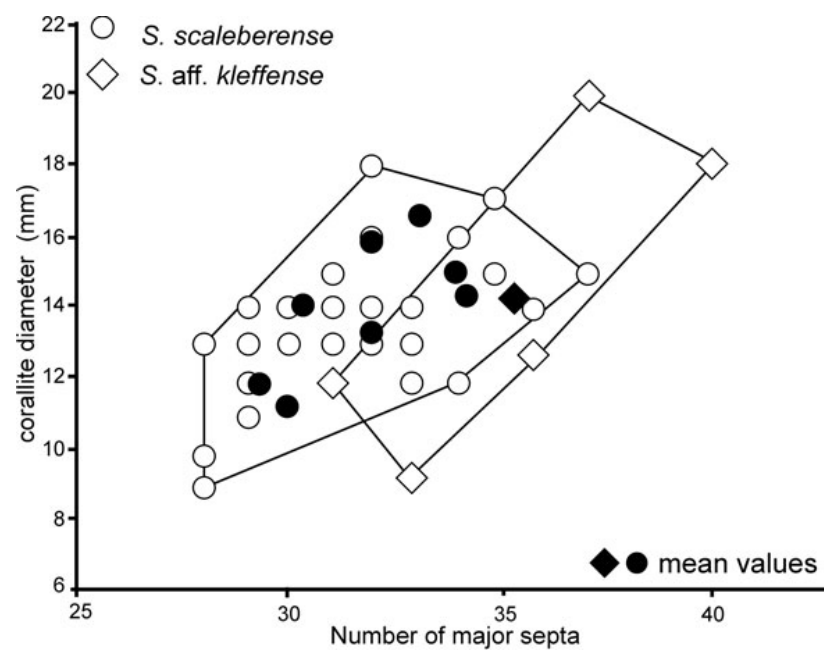

Figure 9. Scatter diagram showing the number of major septa plotted against corallite diameter for Siphonodendron scaleberense Nudds \& Somerville, 1987 and Siphonodendron aff. kleffense (Schindewolf, 1928), based on 35 and 8 measurements respectively. The mean values are given for each colony.

same facies, even in the same beds. The origin of this variability is thus not only ecological or can be explained by temporary (seasonal?) changes in the local environment.

Discussion. - The Turkish specimens differ from the $\mathrm{W}$ European S. martini (Milne-Edwards \& Haime, 1851) by a larger dissepimentarium, however this character should not be considered as sufficient to exclude them from the species. Indeed, colonies figured - among others - by Aretz \& Herbig (2010) and Rodríguez et al. (2002) show commonly up to four rows of dissepiments. S. martini being a long-ranging species (from Moliniacian to Serpukhovian), its morphology can vary slightly. Varieties or stratigraphic and/or geographic subspecies could exist but they need to be documented.

Occurrence. - S. martini is probably the most common Siphonodendron species through the Viséan. It is known from the Moliniacian to the Warnantian in Belgium and British Isles (Poty 1981, 1984; Aretz \& Nudds 2005), in the Warnantian and Serpukhovian of N Africa (Aretz 2010, 2011; Aretz \& Herbig 2010; Rodríguez et al. 2013), SE China (Yü 1933, Lin et al. 2012), and in the Viséan-Serpukhovian of the Russian Platform (Dobroljubova 1958). In NW Turkey, S. martini is present in Zonguldak and Bartın area, in the Moliniacian and Warnantian substages.

\section{Siphonodendron scaleberense Nudds \& Somerville, 1987}

Figure 7E-H

1977 Lithostrotion (Siphonodendron) affine (Fleming). Khoa, p. 336, pl. 4, figs 3a-d.

1985 Siphonodendron sp. B. - Semenoff-Tian-Chansky, pl. 13, fig. 5.

*1987 Siphonodendron scaleberense Nudds \& Somerville; p. 295, figs $2 \mathrm{a}-\mathrm{f}, 5 \mathrm{a}, \mathrm{b}$.

2002 Siphonodendron scaleberense Nudds \& Somerville. Rodríguez et al., p. 33, fig. 17.

2005 Siphonodendron cf. scaleberense Nudds \& Somerville. - Aretz \& Nudds, p. 180, pl. 3, figs 3-5.

2005 Siphonodendron scaleberense Nudds \& Somerville. Cózar et al., fig 12:5.

2010 Siphonodendron scaleberense Nudds \& Somerville.Aretz \& Herbig, p. 302, fig. 6E.

2010 Siphonodendron scaleberense Nudds \& Somerville. Poty, p. 391, fig. 2G.

2011 Siphonodendron scaleberense Nudds \& Somerville. Denayer et al., p. 171, pl. 8, fig. N.

Holotype. - Specimen BM.R49898, Holkerian, Scaleber Quarry, Settle, North Yorkshire; British Museum of National History, London.

Material. - 19 colonies: 11 from Gökgöl section, 1 from Kokaksu, 4 from Topluca and 3 from Süzek.

Diagnosis. - Phaceloid Siphonodendron with large corallites (13-20 $\mathrm{mm}$ in diameter, 10-14 $\mathrm{mm}$ for the tabularium), having 30-41 septa of both orders and at least two rows of interseptal dissepiments. After Nudds \& Somerville (1987).

Description. - Transverse section: The mean diameter of the corallites is $13.6 \mathrm{~mm}$ (maximum $18 \mathrm{~mm}$, Fig. 9) 
while the mean tabularium diameter is $9-11 \mathrm{~mm}$. There are on average 32 septa of both orders (maximum 40). The major ones are usually short and their length does not exceed the half of the corallite radius but in some case, they join the columella. They are thick, sinuous in the dissepimentarium but straight in the tabularium. The cardinal septum is shorter and positioned in a shallow fossula. The counter septum is usually connected to the columella. The minor septa are $1 / 4^{-1 / 3}$ as long as the major but remain restricted to the dissepimentarium. They are often more sinuous than the major. The axial structure is composed of a long (up to $1 / 3$ of the corallite radius in length) axial plate bearing some short septal lamellae. Diphymorphic corallites are occasional (Fig. 7:7). The dissepimentarium comprises 4-8 rows of concentric, $\mathrm{V}$-shaped and herringbone interseptal dissepiments; the inner row is usually thicker. The external wall is regular and thin $(0.2 \mathrm{~mm})$. Longitudinal section: The tabulae are incomplete, the axial series of tabellae are cone-shaped and strongly upturn towards the columella while the periaxial tabellae are flat or concave, depressed towards the dissepimentarium. The dissepiments are $0.7-0.8 \mathrm{~mm}$ long and $1.5-2 \mathrm{~mm}$ high. They are inclined at $70-80^{\circ}$ towards the tabularium but the inner row is almost vertical. There are 10-12 tabulae and 8-16 dissepiments per centimetre height.

Discussion. - The Turkish colonies fit in the definition of S. scaleberense. Their large size makes them easily distinguished from the other Siphonodendron species, except S. ondulosum Poty, 1981 and S. sociale (Phillips, 1836) sharing similar dimensions but differing from the latter by long minor septa and a conspicuous fossula.

Occurrence. $-S$. scaleberense is known from the base of the Warnantian in Belgium (guide of the RC7 $\beta$ biozone of Poty et al. 2006) and is also common in the Asbian of the British Isles (Nudds \& Somerville 1987), SW Spain (Rodríguez et al. 2002) and N Africa (Aretz \& Herbig 2010, Said et al. 2013). In NW Turkey, the species occurs with $S$. asiaticum in the Warnantian in Zonguldak and Bartın areas.

\section{Siphonodendron ondulosum Poty, 1981}

Figures 10B-H, 12A-E

1933 Lophophyllum fraiponti Charles; p. 128, pl. 5, figs 26, 27. (nomen oblitum)

1933 Lophophyllum asmaense Charles; p. 82. (nomem nudum)

?1938 Lithostrotion caswellense Howel; p. 15, pl. 1, figs 23-26.

?1960 Lithostrotion affine tanaicum Vassiljuk; p. 86, pl. 22, fig. 1.
1984 Lithostrotion martini Milne-Edwards \& Haime. - Somerville \& Strank, p. 92, fig. 4h.

1975 Siphonodendron martini (Milne-Edwards \& Haime). Poty, p. 77, pl. 1, figs 1, 2, pl. 2, figs 1-3, pl. 3, figs 2, 9.

?1976 Siphonodendron scoticum (Hill). - Onoprienko, p. 12 , pl. 2, figs 3-5.

?1976 Siphonodendron proliferum (Hall). - Onopirenko, p. 15 , pl. 4, figs $5-7$.

*1981 Siphonodendron ondulosum Poty; p. 26, pl. 8, figs 1-3. (nomen protectum)

?1982 Siphonodendron cf. ondulosum Poty. - Conil et al., pl. 5 , fig. 6.

?1982 Siphonodendron aff. ondulosum Poty. - Conil et al., pl. 5 , fig. 7.

1993 Siphonodendron ondulosum Poty. - Poty, p. 144, figs 7.1, 7.2.

1994 Siphonodendron ondulosum Poty. - Javaux, p. 130, figs 6.1-6.4.

2011 Siphondendron ondulosum Poty. - Denayer et al., p. 171, pl. 6, fig. J.

Holotype. - Colony 45, Neffe Formation, Moliniacian, Corphalie section, Meuse valley, Belgium; Collection Poty, Université de Liège, Belgium.

Remark. - S. ondulosum Poty, 1981 should have been considered as a junior synonyme of $S$. fraiponti (Charles 1933) following the Principle of Priority of the International Code of Zoological Nomenclature. The Code allows exception if the senior synonym has been unused (article 23.9.1 of the Code) and if the junior has been used at least in 25 publications by at least 10 authors during the last 50 years (article 23.9.2). The name fraiponti appears only in 5 publications since its creation by Charles in 1933 and for two of them, the name was misused [synonym of S. martini (Milne-Edwards \& Haime, 1851) after Poty 1975b and Fedorowski \& Bamber 2007] or was misinterpreted as Lophophyllum or Koninckophyllum (e.g. Fedorowski 1971). The junior name ondulosum appears in at least 20 publications covering only the last 30 years. Thus the conditions required to consider fraiponti as a nomen oblitum are not met. Nevertheless, the use of Charles' species leads to troubles because $S$. fraiponti's holotype is not representative of the species (see below), is poorly preserved (silicified) and its description is inaccurate (e.g. contradictions exist between the text and plates). The case should be considered by the Commission of Zoological Nomenclature. Nevertheless, in order to preserve the nomenclatural stability, S. ondulosum Poty, 1981 should be maintained.

Material. - 20 colonies: 8 from the Süzek river section (Bartın), 1 from Topluca, 10 from Kokaksu and specimen IP-10861-02 of Charles' collection (Fig. 10Ba, b). The origin of this sample is imprecise: the thin section of 
Lophophyllum fraiponti is labelled "Asma" (name of the hamlet downstream of Gökgöl section) but in the descriptive paragraph (Charles 1933, pp. 128-129), the author indicates Kokaksu as the origin of the specimen. Moreover, in his description of the Kokaksu section, Charles (1933, p. 82) reports Lophophyllum asmaense nov. sp. There is obviously confusion between the two localities and a mistake in the name given to the species.

Diagnosis. - Siphonodendron with corallites 8-9 $\mathrm{mm}$ large, having 25-28 septa of both orders (maximum 33). Two to six rows of regular interseptal dissepiments. Inner row thickened, forming a stereozone. External wall particularly undulating or arched. Tabulae conical, incomplete. After Poty (1981).

Description. - The colonies are phaceloid, dendroid or subcerioid (Figs 10E, Fd, 12D), up to $1 \mathrm{~m}$ wide and $50 \mathrm{~cm}$ high. Transverse section: The corallites have a mean diameter of $10 \mathrm{~mm}$ (maximum $14 \mathrm{~mm}$, Fig. 11). The mean number of septa of both orders is 28 (maximum 34). The major septa are straight and long, reaching usually the axial structure and connect to it. The minor septa are short (1.5-2 $\mathrm{mm}$ ) and restricted to the most external part of the dissepimentarium where they rarely cross the second row of dissepiments (Fig. 10Fc, G). They are occasionally disrupted by second order lonsdaleoid dissepiments. The cardinal septum is slightly shorter than the other septa. The counter septum is usually longer and connected to the columella (Fig. 12E). The columella is $2-2.5 \mathrm{~mm}$ long and bears rare short and thick septal lamellae. The axial structure is discontinuous vertically in some specimens. The dissepimentarium is made of 6-10 rows of interseptal dissepiments (concentric, angulo-concentric, V-shaped and herringbone, Fig. 10G), the inner rows are densely packed while the innermost is usually thickened and forms a stereozone. Second order lonsdaleoid dissepiments are not rare (Fig. 10Da, b). The external wall is thick $(0.25-0.3 \mathrm{~mm})$ and undulating or arched in fasciculate specimens but straight and festooned in subcerioid parts of the colonies (Fig. 12Ba, C, D). Longitudinal section: The tabulae are incomplete but not clearly separated in axial and periaxial series. The central ones are cone- or tentshaped, upturned towards the axis and some lateral are flat or dome-shaped and interfingered with the others. The dissepiments are $2-4 \mathrm{~mm}$ long and $0.8-1 \mathrm{~mm}$ high, declined at $40-50^{\circ}$ towards the tabularium. There are 16-20 tabulae and 18-20 dissepiments per centimetre height (Fig. 10C).

Discussion. - The Turkish colonies of S. ondulosum Poty, 1981 present several differences with the Belgian ones. 1) The corallites are slightly larger (10 $\mathrm{mm}$ on average versus $8 \mathrm{~mm}$ in Belgian material) and countain more septa (28-30 versus 25-28). 2) Some specimens show lonsdaleoid dissepiments, sometimes numerous and well developed. However, lonsdaleoid dissepiments - even not common were documented in British specimens (Nudds 1993). 3) The subcerioid trend is frequently well marked in some Turkish colonies. Poty (1993) showed that the subcerioid trend occurs in high-energy environments. Indeed phaceloid and subcerioid are never observed in the same beds in Turkish sections. The first occurs in packstone together with fasciculate colonies of Dorlodotia briarti, while subcerioid Siphonodendron are frequent in grainstone and rudstone together with large colonies of Dorlodotia euxinensis also subcerioid. The specimen published as Lophophyllum fraiponti Charles, 1933 is a S. ondulosum, but the specimen presents a narrow dissepimentarium (3-4 rows) proportionaly to its diameter and its tabulae are particularly seldom divided. These features associated with the poor preservation (silicification) of the specimen as well as with the availability of one single corallite argue for dismissing it as a holotype.

Occurrence. - S. ondulosum Poty, 1981 has been described in the Moliniacian of Belgium (Poty 1981, 1984, 1993), in England (Javaux 1994), and possibly in the Omolon Massif (Conil et al. 1982). In NW Turkey the species is abundant in the Kokaksu (Zonguldak) and Süzek section (Bartın), in association with Dorlodotia briarti, D. euxinensis, Ceriodotia bartinensis, Clisiophyllum multiseptatum and Palaeosmilia murchisoni. Subcerioid forms are mainly found in the Kokaksu section, in a level slightly younger than beds yielding fasciculate colonies. Foraminifers from both levels indicate the upper Moliniacian (MFZ11-B).

\section{Siphonodendron kleffense (Schindewolf, 1928)}

Figure 7I

1928 Siphonodendron (Cystidendron) kleffense Schindewolf; p. 149, tab. 2.

*2000 Siphonodendron kleffense (Schindewolf). - Weyer, pl. 2, fig. 4a, b.

?2002 Siphonodendron aff. martini (M.-E. \& H.). - Rodríguez et al., p. 34, fig. 18.

2011 Siphonodendron kleffense (Schindewolf). - Denayer et al., p. 170, pl. 8, fig. O, P.

2013 Siphonodendron gr. kleffense (Schindewolf). - Aretz et al., p. 92, fig. 4E.

Lectotype. - Schindewolf (1928) did not designte any holotype, described very superficially the specimen and figured only a very schematic longitudinal section of his new subgenus Cystidendron of which C. kleffense is the type species. The species is consequently a nomen nudum. However, Weyer (2000) figured one of Schindewolf's specimens (No. X10226) as the lectotype of the species which he 

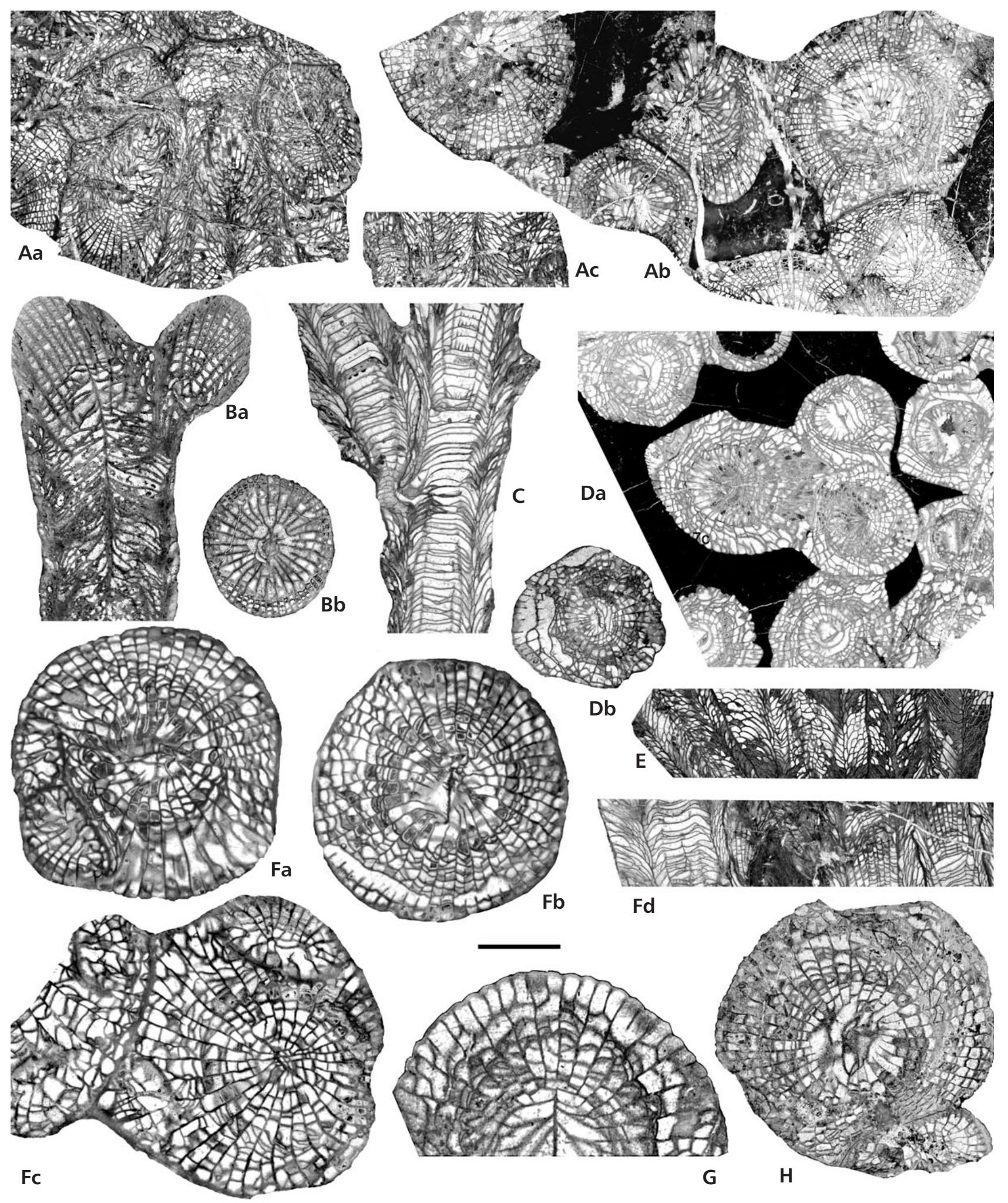

Fd
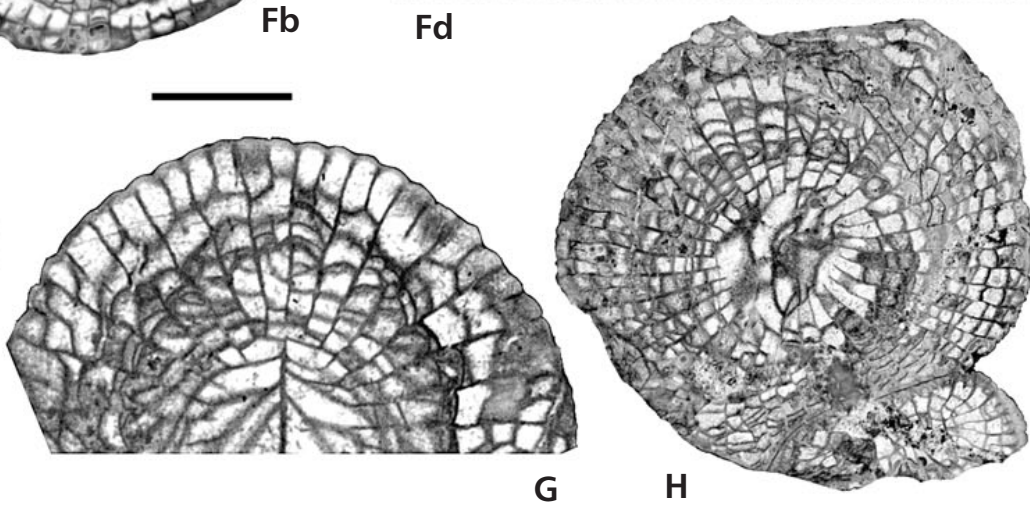

Figure 10. A - Siphonodendron aff. kleffense (Schindewolf, 1928) (Warnantian-Late Viséan), specimen IP-15123-01 from Kokaksu (coll. Charles), $\mathrm{Aa}, \mathrm{Ab}-$ successive TS $(\times 2)$, Ac $-\mathrm{LS}(\times 2)$. $・ \mathrm{~B}-\mathrm{H}-$ Siphonodendron ondulosum Poty, 1981 (Moliniacian-Early Viséan); B - IP-10861-02 (type of Lophophyllum fraiponti Charles, 1933) from Kokaksu (?), Ba - LS (×2), Bb - TS (×2); C - SR.4.9 from Süzek, LS (× 2); D - K.4.10 from Kokaksu showing lonsdaleoid dissepiments, Da, Db - successives TS $(\times 2)$; E - SR.5.24 from Süzek showing a subcerioid trend, LS $(\times 2)$; F - SR.5.6 from Süzek, Fa-c - offsetting corallites, TS $(\times 4), \mathrm{Fd}-\mathrm{LS}(\times 2) ; \mathrm{G}-\mathrm{K} .4 .5$, close view of the dissepimentarium and short minor septa, TS $(\times 4) ; \mathrm{H}-\mathrm{K} .7 .5$, one of the larges corallite observed, TS ( $\times 3$ ). Scale bar equals $7.5 \mathrm{~mm}$ for A-E, Fd, $5 \mathrm{~mm}$ for $\mathrm{H}$ and equals $3.75 \mathrm{~mm}$ for $\mathrm{Fa}-\mathrm{c}, \mathrm{G}$. 


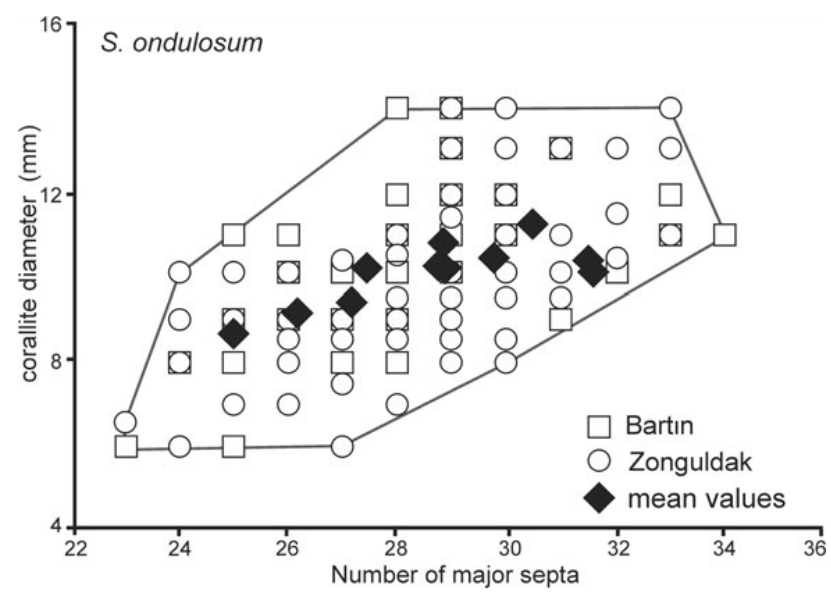

Figure 11. Scatter diagram showing the number of major septa plotted against corallite diameter for Siphonodendron ondulosum Poty, 1981, based on 140 measurements. The mean values are given for each colony.

transferred to the genus Siphonodendron McCoy, 1849. S. kleffense has not been revised yet but the diagnosis published in Denayer et al. (2011) - based on Schindewolf's material and newly collected specimen from the Visé area - acts as an emended definition.

Material. - One small fragment of a colony from the Süzek section.

Diagnosis. - Dendroid to subcerioid colonies with large corallites (7-12 $\mathrm{mm}$ in diameter, 4-8 $\mathrm{mm}$ for the tabularium) having 28-32 septa of both orders. Major septa long, sinuous in the dissepimentarium, straight in the tabularium, often connected to the columella. Dissepimentarium comprising 4-6 rows of interseptal dissepiments, inner row thickened. Tabulae incomplete: axial tabellae upturned towards the columella, periaxial tabellae declined towards the dissepimentarium. After Denayer et al. (2011).

Description. - Transverse section: The mature corallites have a mean diameter of $10 \mathrm{~mm}$ (maximum $11 \mathrm{~mm}$, Fig. 8) and 30-32 septa of both orders. The major septa are long and reach the axis. They are straight in the tabularium, thin or slightly thickened in their middle part. The minor septa are half as long as the major but never cross the inner edge of the dissepimentarium. The cardinal septum is usually a bit shorter than the others and often more tortuous. The counter septum is thinner and longer than the other septa and is commonly connected to the columella. Some corallites show slightly shorter alar septa. The columella is a long $(1.5-2.5 \mathrm{~mm})$ and thin $(0.3-0.6 \mathrm{~mm})$ styliform plate devoid of septal lamellae. The cardinal fossula is shallow and marked by the withdrawal of the cardinal septum and the dissepimentarium. The dissepimentarium is composed of 4-5 rows of concentric or herringbone (in large corallites) interseptal dissepiments. The inner row is thickened and forms a stereozone. The external wall is regular and thick $(0.4 \mathrm{~mm})$.

Discussion. - With 28-32 major septa and 7-8 mm diameter, S. kleffense (Schindewolf, 1928) can easily be distinguished from $S$. martini (Milne-Edwards \& Haime, 1851) (23-25 septa for a similar diameter) and from $S$. ondulosum Poty, 1981 (25-28 septa, 9-10 mm diameter). S. scaleberense Nudds \& Somerville, 1987 and S. sociale (Phillips, 1836) are both larger and have a lower ratio of number of septa to diameter. Specimens attributed to $S$. aff. martini from the upper Viséan of SW Spain by Rodríguez et al. (2002) is questionably $S$. kleffense sharing with this species similar dimensions and number of septa but showing a simpler tabularium.

Occurrence. - The species is known in the lower Warnantian (RC7 biozone of Poty et al. 2006) in the Visé area and Campine Basin (NE Belgium, Poty, pers. com.) and W Germany (Weyer 2000). It has recently been signalled in the Moroccan Tafilalt (Aretz et al. 2013). In Turkey, S. kleffense was found with S. asiaticum and S. scaleberense in the upper part (lower Warnantian) of the Süzek section (Bartın).

\section{Siphonodendron aff. kleffense (Schindewolf, 1928)} Figure 10Aa-c

Material. - 3 colonies: one belonging to Charles' collection (not figured in his 1933 publication), coming from the Kokaksu section; the others come from the Kokaksu and Kisla sections.

Description. - These colonies show a strong subcerioid trend, corallites being either cylindrical and isolated or prismatic in the same colony. The corallites in cerioid zones are usually smaller and have less septa than in the fasciculate ones (Fig. 10Aa). Transverse section: The corallites have a mean diameter of $13.8 \mathrm{~mm}$ (maximum $20 \mathrm{~mm}$, Fig. 9) with a tabularium measuring $8.5 \mathrm{~mm}$ on average (maximum $11 \mathrm{~mm}$ ) and have 31-40 septa of both orders. The major septa are long and straight in the dissepimentarium, wheras they are slightly curved in the tabularium.

Figure 12. A-E - Siphonodendron ondulosum Poty, 1981 (Moliniacian-Early Viséan). • A - specimen SR.5.6 from Süzek, TS (× 2); Ba, Bb - SR.5.4 from Süzek, successive TS $(\times 2)$; C - SR.4.9 from Süzek showing diphymorphic corallites, TS $(\times 2)$; D - K.4.5 from Kokaksu, TS $(\times 2)$; E - SR.5.24 from Süzek, close view of the columella, TS $(\times 6)$. Scale bars equals $7.5 \mathrm{~mm}$ for A-D and $2.5 \mathrm{~mm}$ for E. 
Julien Denayer • Viséan Lithostrotionidae (Rugosa) from NW Turkey
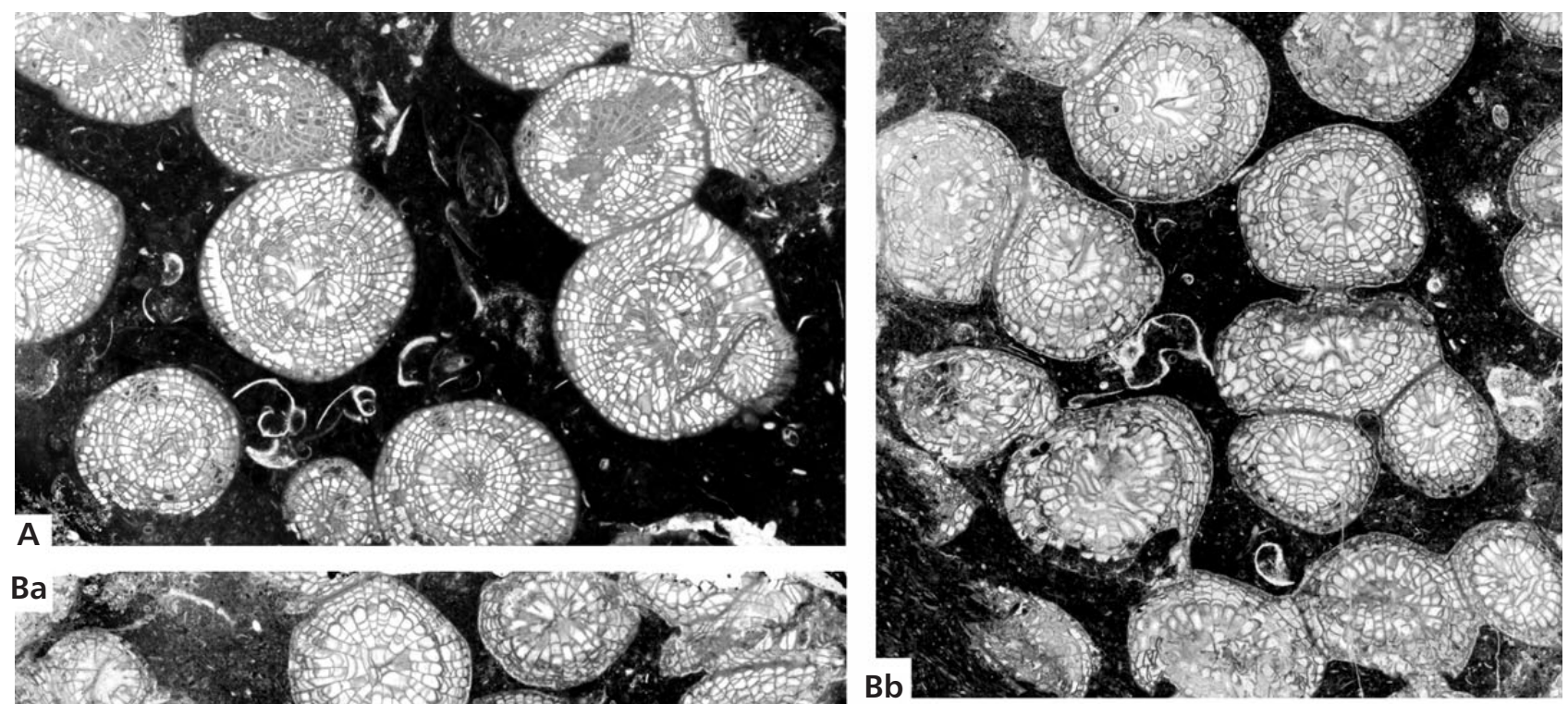

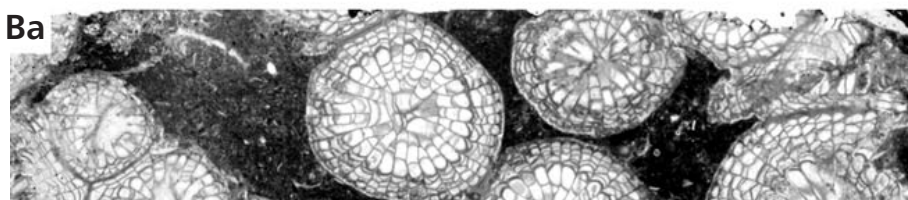
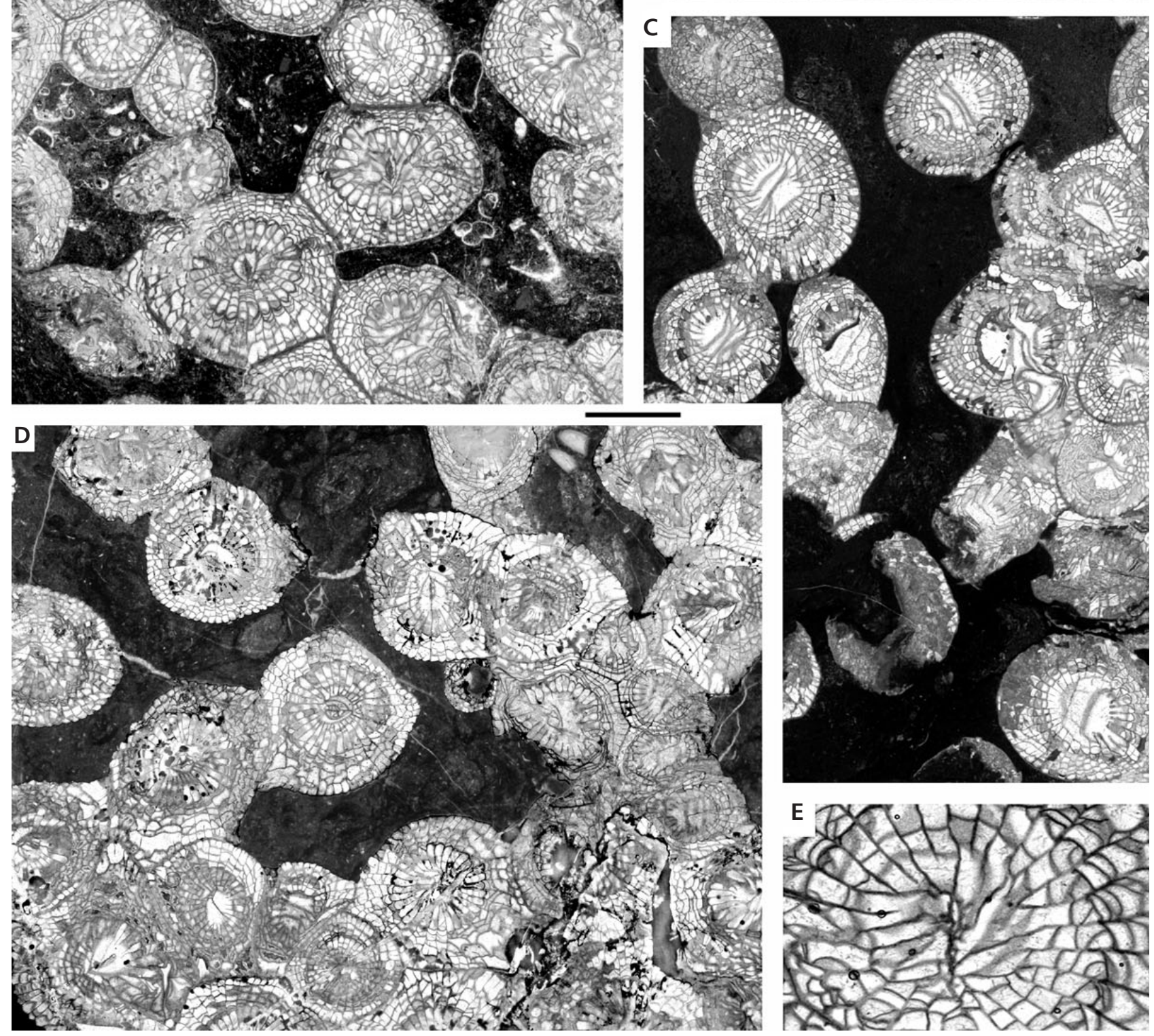
The minor septa are long and enter into the tabularium but are thinner than the major ones. The axial structure is made of a thin columella, usually poorly defined and with numerous septal lamellae. The dissepimentarium comprises 4-7 rows of concentric and V-shaped interseptal dissepiments, the two inner rows being usually herringbone. The external wall is regular and thin. Longitudinal section: The tabulae are incomplete but not separated in axial and periaxial series, dome- or cone-shaped and declined towards the periphery. The dissepiments are small (1-1.5 mm long and high). There are 15-17 tabulae and 15 dissepiments per centimetre height.

Discussion. - The large dimensions of the corallites and the high number of septa compare to $S$. scaleberense Nudds \& Somerville, 1987 and S. sociale (Phillips, 1836) but the subcerioid trend is unknown in these species. Contrarily, S. kleffense (Schindewolf, 1928) show commonly a cerioid habitus but its dimensions are generally smaller. The present specimen possibly belongs to a new species but the material is unfortunately not sufficient for accurate description and comparison.

Occurrence. - S. aff. kleffense occurs in the Warnantian (foraminifers indicate the MFZ14 biozone) of Kokaksu and Kisla sections. Subcerioid S. kleffense are known in time-equivalent levels in Visé area and Campine Basin (E. Poty, pers.comm.).

\section{Genus Lithostrotion Fleming, 1828}

Type species. - Lithostrotion striatum Fleming, 1828, synonym of Lithostrotion vorticale (Parkinson, 1808), Viséan, England, Fleming's holotype being lost (Kato 1971).

Diagnosis. - Coral forming cerioid colonies with prismatic corallites presenting a calicular platform surrounding a central depression occupied by the axial structure. Major septa long, reaching the axis. Minor septa short, restricted to the dissepimentarium or entering slightly into the tabularium. Axial structure made of an axial plate bearing septal lamellae. Numerous interseptal dissepiments, seldom transeptal dissepiments. Tabularium narrow. Tabulae usually incomplete. Axial tabellae conical. Periaxial tabellae flat, subhorizontal or declined towards the periphery. Lateral, intermural and non-parricidal increase. After Poty (1981).

Discussion. - Often confused with Siphonodendron in the older literature, the name Lithostrotion must be retained for the cerioid forms of lithostrotionid corals as suggested by Schindewolf (1928), Hill (1934), Poty (1975a) and Nudds \& Somerville (1987). Scrutton (1983) documented ducts crossing the wall between corallites in cerioid forms but not in fasciculate ones. Nevertheless, such ducts are commonly observed in Siphonodendron where they connect the offsets to the mother corallite, at least during the first stages of development (see Fig. 10C). This connection constitutes the first step of the integration process leading to highly integrated colonies within the plocoid forms of lithostrotionids (Orionastraea Smith, 1916 and Pleionastraea Nudds, 1999) but is not a generic character. In shallow water high-energy environment, S. ondulosum Poty, 1981 tends to acquire a subcerioid habitus that leads, after Poty (1993) to the appearance of L. araneum (McCoy, 1844) by paedomorphosis in the Livian. This author identified a neotenic process in the separation of the offsets from its parent corallite, so delayed that the two corallites stay permanently joined and connected (Poty 1993, 2010). The discovery of Lithostrotion potii sp. nov. (see below) in the upper Moliniacian of Bartın does not cast doubt on Poty's phyletic model but modified the actors. L. potii originates probably in large sized-corallite subcerioid colonies of S. ondulosum through the same evolutionary process highlighted by Poty (1993). L. potii is the oldest species of the genus and probably gave rise to L. araneum in the uppermost Moliniacian or lowermost Livian through a reduction in size and number of septa. Poty $(1984,1993)$ documented in the Viséan of W Europe a heterochronic lineage L. araneum - vorticale - decipiens - maccoyanum characterized by a progressive decrease of size of the corallites governed by progenesis.

\section{Lithostrotion potii sp. nov.}

Figures 13, 14A-D

Etymology. - This oldest Lithostrotion species is dedicated to Prof. E. Poty for his work on Carboniferous rugose corals.

\section{Holotype. - Colony SR.5.21/ Bartın/2011.}

Type horizon and locality. - Unit SR5: light grey massive limestone with Ceriodotia. Foraminifers indicate the MFZ11B zone of Hance et al. (2011), i.e. the uppermost Moliniacian. Süzek section, $3 \mathrm{~km}$ NE of Bartın, NW Turkey.

Figure 13. A-D - Lithostrotion potii sp. nov. (Moliniacian-Early Viséan). A - specimen SR.5.18 (holotype) from Süzek, Aa-c - successive TS (× 2); B -SR.5.8 from Süzek, TS (×3); C - SR.5.21 from Süzek, TS (×2); D - SR.5.13 from Süzek, LS (×2). Scale bar equals 7.5 mm for A, C, D and 5 mm for B. 


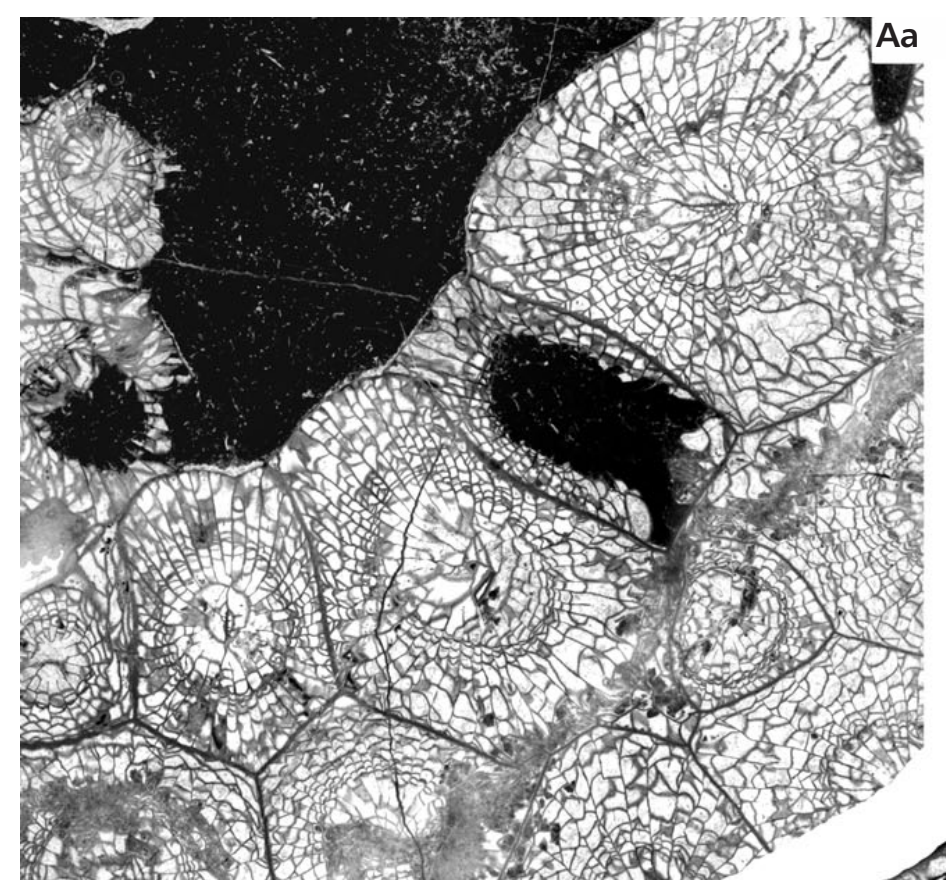

Ab Xin

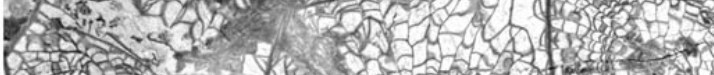

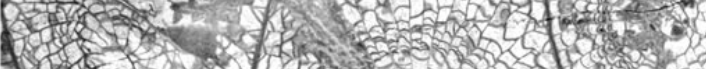
1.6. - 2 (3) 3 .

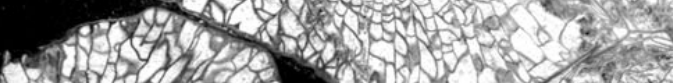

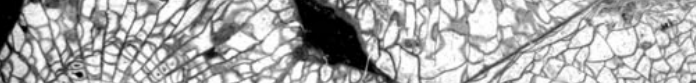

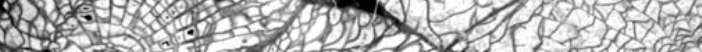
(15.7)

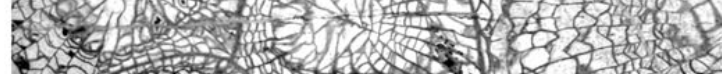

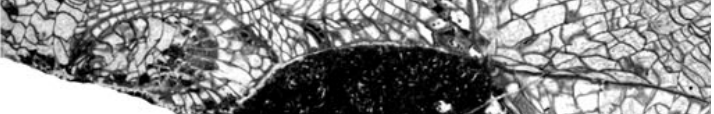

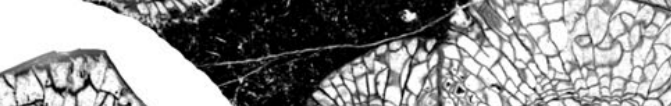

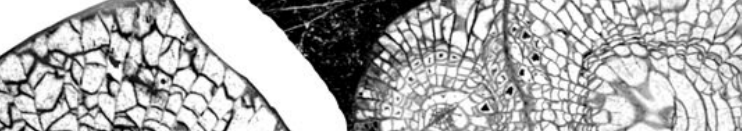
350 (2)

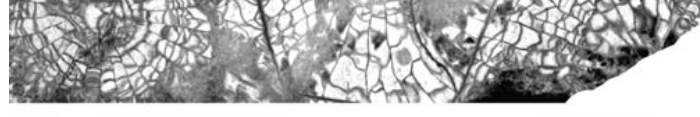

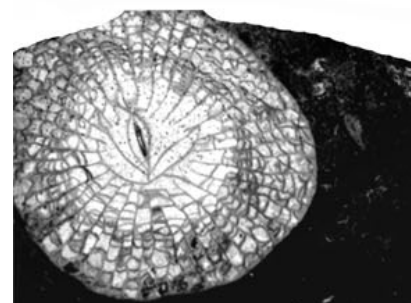

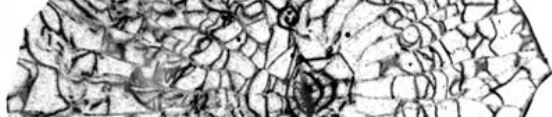
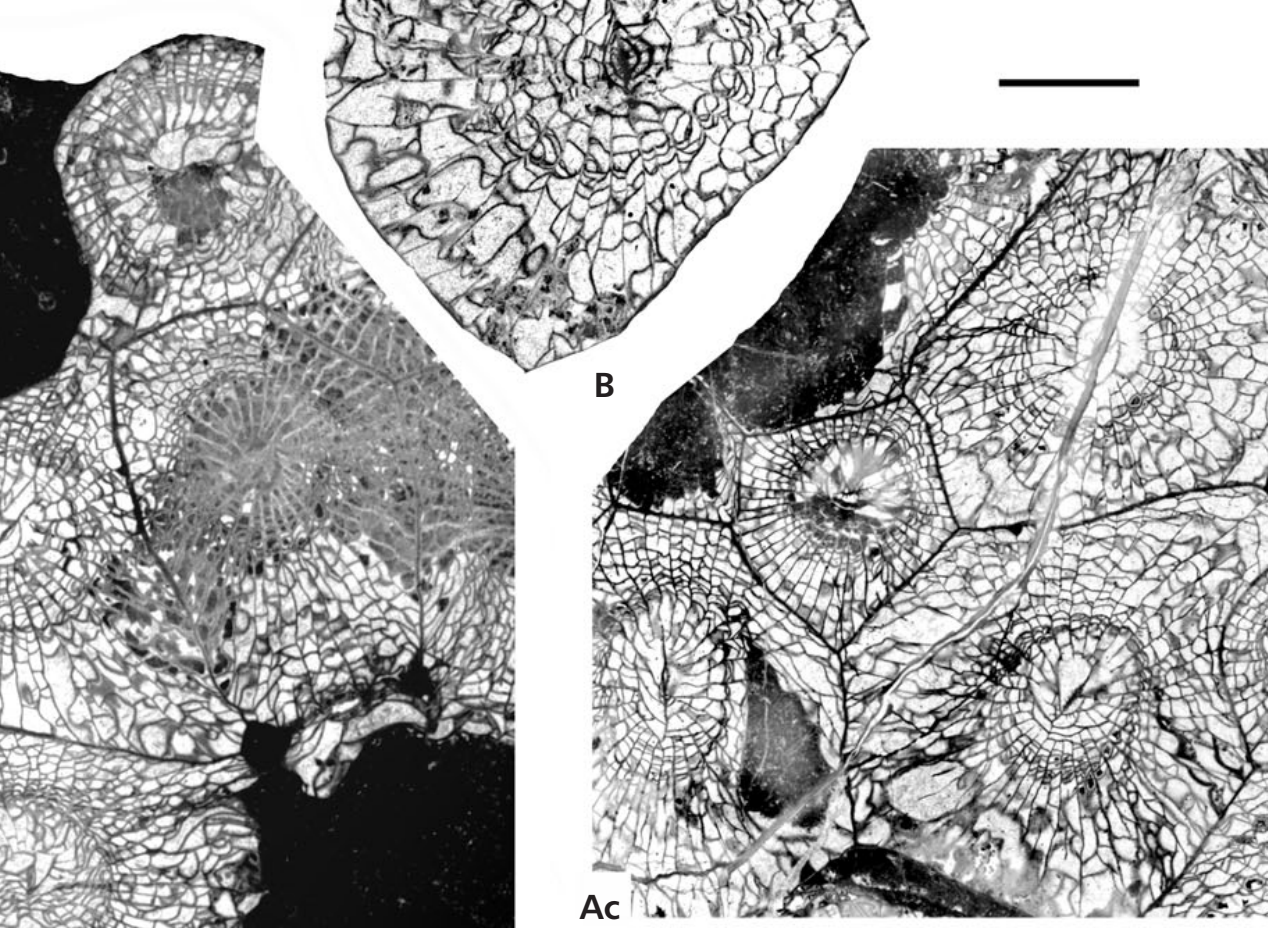
ris

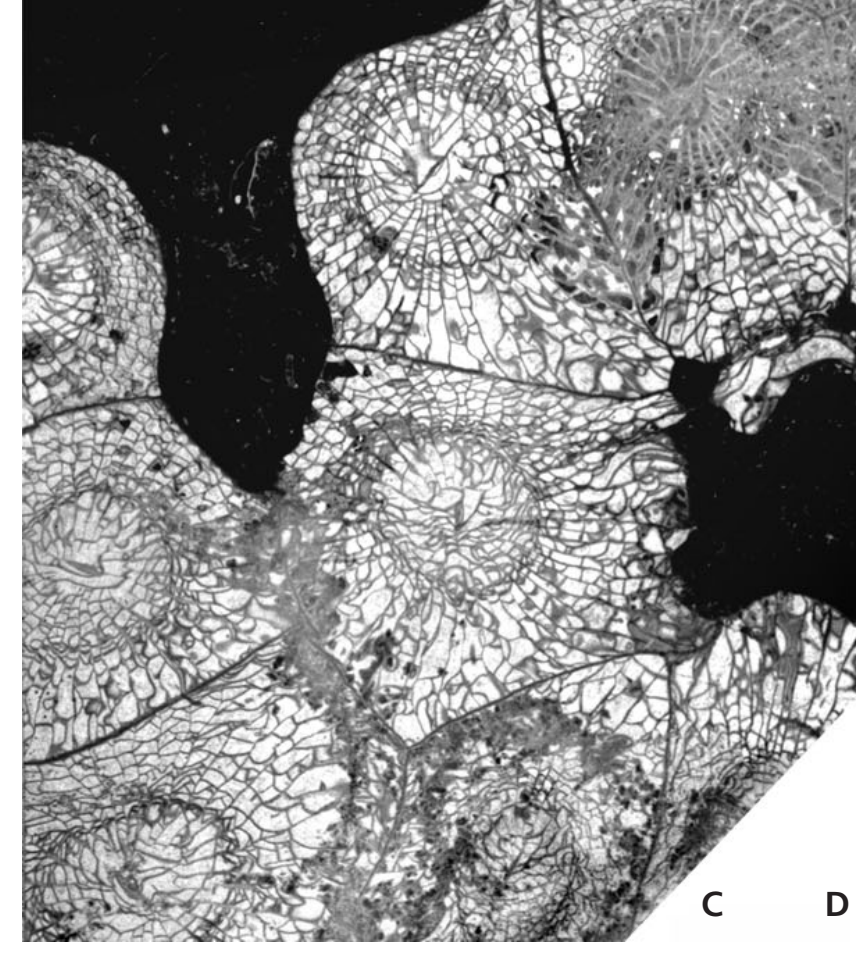
co

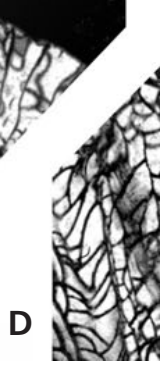

- Iffeg

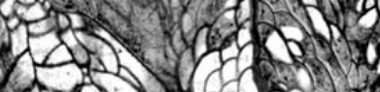

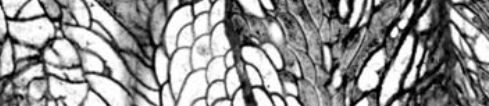
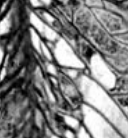
(1) ot 
Diagnosis. - Lithostrotion with large-sized corallites (15-20 $\mathrm{mm}, 8-10 \mathrm{~mm}$ for the tabularium) having 26-28 septa of both orders. Major septa long and thin. Minor septa variable in length, entering into the tabularium or withdrawn towards the periphery of the dissepimentarium. Dissepimentarium wide, composed of 10 or more rows of dissepiments.

Material. - Five colonies including the holotype (10 TS, 3 LS) from Süzek section.

Description. - Colonies are $10 \mathrm{~cm}$ high and up to $20 \mathrm{~cm}$ wide. They are cerioid but show occasionally subcerioid corallites in the periphery. Transverse section: The mature corallites are 10-20 $\mathrm{mm}$ large (maximum $22 \mathrm{~mm}$ ) with a mean tabularium diameter of $8 \mathrm{~mm}$ (maximum $11 \mathrm{~mm}$, Fig. 15) and have 26-28 septa of both orders (maximum 36, Fig. 15). The major septa are thin or slightly thickened in the tabularium where they are straight. They can be sinuous in the dissepimentarium; their axial ends are sharp. The length of the minor septa is variable. They can be reduced to short septal crests on the outer wall or extend up to the tabularium (Figs 13B, $14 \mathrm{Cc})$. They are thin tortuous and discontinuous in the peripheral part of the dissepimentarium. Both cardinal and counter septa are long and connected to the columella (Fig. 14Ba). The cardinal fossula is shallow and marked by a withdrawal of the dissepimentarium. The columella is long, thin and sinuous. Some septal lamellae can occur and are confluent with the axial ends of some major septa (Fig. 14Ba, b). Rare diphymorphic corallites were observed. The dissepimentarium is wide and comprises 10-13 rows of dissepiments: concentric interseptal dissepiments in the outer part, anguloconcentric and V-shaped in the middle part and herringbone in the inner part of the dissepimentarium. The 3 or 4 inner rows are densely packed but not thickened. First and second order lonsdaleoid dissepiments occur in the largest corallites, some of them being naotic. The external wall is regular, $0.2-0.3 \mathrm{~mm}$ thick but can be thicker and undulating in corallites situated in the periphery of the colonies. Longitudinal section: The tabulae are incomplete, with the axial series interfingered into the periaxial series of tabellae. The axial tabulae are cone- or tent-shaped, strongly upturned towards the axis and can be tangential to the columella in places. The periaxial tabellae are dome- or bell-shaped or concave upside and declined towards the dissepimentarium. A peripheral gutter occurs in some specimens (Fig. 13D). The dissepiments are long but narrow, subvertical in the inner part of the dissepimentarium, larger and less declined in the periphery. The outer row (naotic) is almost vertically disposed. There are 20 tabulae and 18-20 dissepiments per centimetre height.
Variability. - The intra-specific variability affects particularly the length of the minor septa and the development of the columella. As stated before, in the periphery of colonies, some corallites are cylindrical and show a subcerioid trend (Fig. 13C). It is obviously an ecological phenomenon (different growth condition for different location of corallites in the colony) but these cylindrical corallites are very similar to the large sized-corallites of S. ondulosum observed in the underlying beds, which argues for a phyletic relationship between the two species.

Increase. - The smallest observed offsets are 3.5-4 mm large and comprise about 20 short and tortuous septa. Fragments of a thick wall rapidly develop between the offset and its parent. Irregular dissepiments - including lonsdaleoid - appear rapidly, before the wall is fully developed (Fig. 14Ca, b). The columella is the last element to form while the corallite tabularium is about $5 \mathrm{~mm}$ large. It stays connected to both the cardinal and counter septa.

Discussion. - The large dimensions (including the dissepimentarium width) and the higher number of septa allow an easy discrimination of $L$. potii sp. nov. and L. araneum (McCoy, 1844). The largest corallites of L. araneum however may have a high number of septa (up to 32, Poty 1981), overlapping the variability of L. potii. Moreover, the minor septa, even if very variable in length, are often entering into the tabularium while they are most commonly restricted to the dissepimentarium in L. araneum. The dissepimentarium is also larger in the new species and does not include any thicker row as commonly observed in L. araneum. Smal-sized corallites, corresponding to immature stages, are very similar to the mature corallites of L. araneum: equivalent diameter and number of septa, short minor septa and narrow dissepimentarium. These similarities, together with the stratigraphic distribution of the two species suggest close relationship between L. potii and L. araneum and probably a phyletic lineage. The Livian species appears probably through a reduction of size and a simplification of the dissepimentarium. L. potii shares with large corallites of S. ondulosum a similar tabularium diameter $(8-11 \mathrm{~mm}$ for the first, 9-11 $\mathrm{mm}$ for the second), a similar size (15-19 $\mathrm{mm}$ for cylindrical corallites of $L$. potii and $14-18 \mathrm{~mm}$ for $S$. ondulosum corallites) and number of septa (26-36 for L. potii, 28-34 for S. ondulosum). They both show occasional transeptal dissepiments.

Occurrence. - Lithostrotion potii sp. nov. is the oldest species of the genus, known only in the Ceriodotia beds of NW Turkey. The foraminifers (primitive Pojarkovella) indicate the uppermost Moliniacian MFZ11B zone of Hance et al. (2011). 


\section{Lithostrotion araneum (McCoy, 1884)}

Figure 14Ea-c

*1844 Astrea aranea McCoy; p. 187, pl. 17, fig. 6.

?1958 Lithostrotion basaltiforme Phillips. - Dobroljubova, p. 178 , pl. 28 , fig. 2 .

1981 Lithostrotion araneum (McCoy). - Poty, p. 20, pl. 4, figs 1-4. [cum syn.]

1983 Lithostrotion araneum (McCoy). - Scrutton, fig. 9.

1993 Lithostrotion araneum (McCoy). - Poty, fig. 7.3.

1994 Lithostrotion araneum (McCoy). - Poty \& Hannay, p. 63 , pl. 4 , fig. 1 .

?2003 Lithostrotion basaltiforme Phillips. - Fan et al., p. 320 , pl. 39 , figs 4,5 .

2005 Lithostrotion araneum (McCoy). - Cózar et al., fig. 12:4.

2010 Lithostrotion araneum (McCoy). - Aretz, p. 331, fig. 5c. [cum syn.]

2011 Lithostrotion araneum (McCoy). - Denayer et al., p. 171, pl. 7, fig. M.

2012 Lithostrotion araneum (McCoy). - Denayer, p. 322, fig. 7D.

Holotype. - Specimen 50-1926, unknown origin; National Museum of Ireland, Dublin. Specimen F7467/1-3 is a syntype after Mitchell (1989).

Material. - 2 colonies from Gökgöl (Zonguldak).

Diagnosis. - Lithostrotion with corallites 12-18 mm large with a mean tabularium diameter of 4.5-5.5 mm, having 23-26 septa of both orders. Dissepimentarium wide, made of concentric, V-shaped and herringbone interseptal dissepiments. After Poty (1981, 1993).

Description. - The corallites are polygonal, 9-12 mm large (maximum $15 \mathrm{~mm}$, Fig. 15). The mean tabularium diameter is $5.5 \mathrm{~mm}$ (maximum $7 \mathrm{~mm}$ ). There are 21-24 septa of both orders (maximum 26). The major septa are long and several reach the axis. The cardinal septum is slightly shorter. The counter septum is usually longer and connected to the columella. The minor septa are $1 / 3-1 / 2$ as long as the major and restricted to the dissepimentarium. The columella is $1.5-2 \mathrm{~mm}$ long, is often thickened and bears rare short septal lamellae (Fig. 14Ec). The dissepimentarium is composed of 7-12 rows of concentric, V-shaped and herringbone interseptal dissepiments. The inner row is thickened and forms a stereozone (Fig. 14Ea, b). The external wall is $0.25 \mathrm{~mm}$ thick and regular.

Discussion. - Except for a slightly narrower dissepimentarium, the Turkish specimens are identical to L. araneum from Belgium and the British Isles (Poty 1981). L. araneum is smaller than L. potii but larger than the other spe- cies of the genus (L. vorticale, L. decipiens and L. maccoyanum).

Occurrence. - L. araneum was considered as the oldest species of the genus and still is in W Europe. It is the guide taxa for the Livian RC6 coral biozone of Poty et al. (2006) but is also present is the Warnantian RC7 biozone. The species is present in Belgium, N France (Poty \& Hannay 1994), British Isles (Mitchell 1989), SW Spain (Rodríguez et al. 2002), Morocco (Said et al. 2007, Aretz 2010) and Algerian Sahara (Semenoff-Tian-Chansky 1985). Similar forms were described in the Kuznetsk Basin (Dobroljubova 1958) and S China (Fan et al. 2003). L. araneum has been documented in the central Anatolides (Kongul Yayla: Denayer 2012). In NW Turkey, L. araneum occurs together with Siphonodendron asiaticum and $S$. scaleberense (RC7 $\beta$ subzone) in the base of the Warnantian stratified cherty limestone of the Gökgöl section.

\section{Lithostrotion vorticale (Parkinson, 1808)}

Figure 16A

*1808 Madrepora vorticalis Parkinson; p. 45, pl. 5, figs 3, 6 .

1981 Lithostrotion vorticale (Parkinson). - Poty, p. 22, pl. 5, figs 1-4. [cum syn.]

1983 Lithostrotion vorticale (Parkinson). - Scrutton, p. 137, fig. 10.

1985 Lithostrotion decipiens (McCoy). - S.-T.-C., pl. 14, fig. 1.

?1990 Lithostrotion pelhatae Vuillemin; p. 86, pl. 20, fig. 1.

?1993 Lithostrotion vorticale (Parkinson). - Lin \& Rodríguez, p. 24, pl. 2, figs 2a, b.

2005 Lithostrotion vorticale (Parkinson). - Aretz \& Nudds, p. 175, pl. 2, fig. 8. [cum syn.]

2005 Lithostrotion vorticale (Parkinson). - Cózar et al., fig. 12.3.

2010 Lithostrotion vorticale (Parkinson). - Aretz \& Herbig, p. 300, fig. 6A.

2011 Lithostrotion vorticale (Parkinson). - Aretz, p. 610, figs $9,10$.

2011 Lithostrotion vorticale (Parkinson). - Denayer et al., p. 171 , pl. 8, fig. J.

2012 Lithostrotion vorticale (Parkinson). - Somerville et al., p. 311, fig. 3C.

2013 Lithostrotion vorticale (Parkinson). - Said et al., p. 374 , fig. 5 I.

Holotype. - Parkinson's holotype is lost and no lectotype has been designated yet (Semenoff-Tian-Chansky \& Nudds 1979).

Diagnosis. - Lithostrotion with medium-sized corallites having a mean tabularium diameter of $3.3-4.1 \mathrm{~mm}$ and 
20-24 septa of both orders. Dissepimentarium made of concentric, V-shaped and herringbone interseptal dissepiments. After Poty (1981, 1993).

Material. - Three fragments of small colonies from the uppermost part of the Kokaksu section (Zonguldak).

Description. - Small colonies counting 4-8 prismatic corallites. Transverse section: The mean tabularium diameter is $4.7 \mathrm{~mm}$ (maximum $6 \mathrm{~mm}$ ). There are 20-22 septa of both orders (maximum 24, Fig. 17). The major septa are long, extending almost to the axis, some of them are connected to the columella, including the cardinal and counter septa. The minor septa are half as long as the major but enter into the tabularium. The columella is $1-2 \mathrm{~mm}$ long and $0.4-0.6 \mathrm{~mm}$ thick. The dissepimentarium is composed of 3-4 rows of small concentric interseptal dissepiments. The external wall is thin and regular.

Discussion. - These colonies show all the morphologic features and size of the species $L$. vorticale. They can be easily discriminated from the other species by their dimensions (L. decipiens and L. maccoyanum are smaller, L. araneum and L. potii are both larger).

Occurrence. - L. vorticale occurs in the Livian and Warnantian of Belgium (Poty 1981) and the British Isles (Mitchell 1989), in the Warnantian of SW Spain (Rodríguez et al. 2002), in the Algerian Sahara (Semenoff-Tian-Chansky 1985) and Morocco (Aretz 2010, Rodríguez et al. 2012). In NW Turkey, the species is known in the silicified limestone forming the top of the Yllanl1 Formation in the Kokaksu section. The foraminifers indicate the MFZ14 zone (top of the lower Warnantian, i.e. Asbian) but the entry of Palastraea konincki (Charles, 1933) a couple of metres below indicates the late Warnantian (i.e. Brigantian).

\section{Lithostrotion sp.}

Figure $16 \mathrm{Ba}-\mathrm{c}$

Material. - One small colony from Kokaksu.

Description. - The corallites are prismatic and 12-18 mm large. The mean tabularium diameter is $7.5 \mathrm{~mm}$ (maximum $9 \mathrm{~mm}$, Fig. 17). They have 27 septa of both orders on average (maximum 31). Major septa are long but do not reach the axis, except the counter septum, which is connected to the columella. The minor septa are half as long as the major and enter in the tabularium for more than $1 \mathrm{~mm}$. The columella is 3-5 mm long. There are 6-9 rows of concentric and V-shaped interseptal dissepiments. The inner row is slightly thickened. The external wall is thin $(0.2 \mathrm{~mm})$ and regular. The tabulae are dome-shaped. The dissepiments are declined towards the tabularium at $45^{\circ}$ (Fig. 16Bc).

Discussion. - This colony is obviously a Lithostrotion and is quite similar to L. araneum but differs from the latter by its larger corallites: the smallest observed corallite has a tabularium $8 \mathrm{~mm}$ large ( $5 \mathrm{~mm}$ on average in $L$. araneum). Its dissepimentarium comprises fewer rows than in L. araneum and its minor septa are shorter. The present specimen is similar to L. potii but the latter has a tabularium proportionaly larger. Finally, this specimen is very similar to unpublished material from the upper Viséan of the Campine Basin (NE Belgium, Poty, pers. comm.)

Occurrence. - L. sp. was collected in the upper part of the Y1lanlı Formation in the Kokaksu section together with S. asiaticum (lower Warnantian).

\section{Genus Nemistium Smith, 1928}

Type species. - Nemistium edmondsi Smith, 1928, Brigantian of England.

Diagnosis. - Fasciculate corals with cylindrical corallites. Major septa long reaching the axis or not. Minor septa long. Axial structure - often lacking - made of a thin columella with some septal lamellae connected to the axial ends of the septa. Dissepimentarium narrow, composed of concentric, V-shaped and herringbone interseptal dissepiments. Tabulae incomplete. Axial tabulae strongly upturned towards the columella. Increase axial, parricidal bi-, tri- or quadri-partite. Modified from Hill (1981).

Discussion. - In the original definition, Smith (1928) based his new genus on the presence of a complex axial structure but the absence or discontinuity of the columella in other species led Poty (1984) to consider this feature as a specific character more than a generic one. After Poty's (1984) phyletic model, Nemistium originated in Siphonodendron through the acquisition of a parricidal increase. In the

Figure 14. A-D - Lithostrotion potii sp. nov. (Moliniacian-Early Viséan); A - specimen SR.5.13 from Süzek, TS ( $\times 2$ ); B - SR.5.18 (holotype), $\mathrm{Ba}, \mathrm{Bb}-$ close view-up of the columella, TS $(\times 4)$; C - SR.5.8 from Süzek, Ca, Cb - offsetting corallites, TS $(\times 4)$, Cc - close-up view of the dissepimentarium with minor septa of various length, TS $(\times 4)$, Cd - TS $(\times 2)$; D - SR.5.21 from Süzek, TS $(\times 2)$ ) $・$ E - Lithostrotion araneum $($ McCoy, 1844) (Warnantian-Late Viséan), G.15.5 from Gökgöl, Ea, Eb - successive TS $(\times 2)$, Ec - close-up view of the columella, TS $(\times 4)$. Scale bar equals $7.5 \mathrm{~mm}$ for A, Cd, D, Ea, Eb and equals $3.75 \mathrm{~mm}$ for Ba, Bb, Ca-c, Ec. 

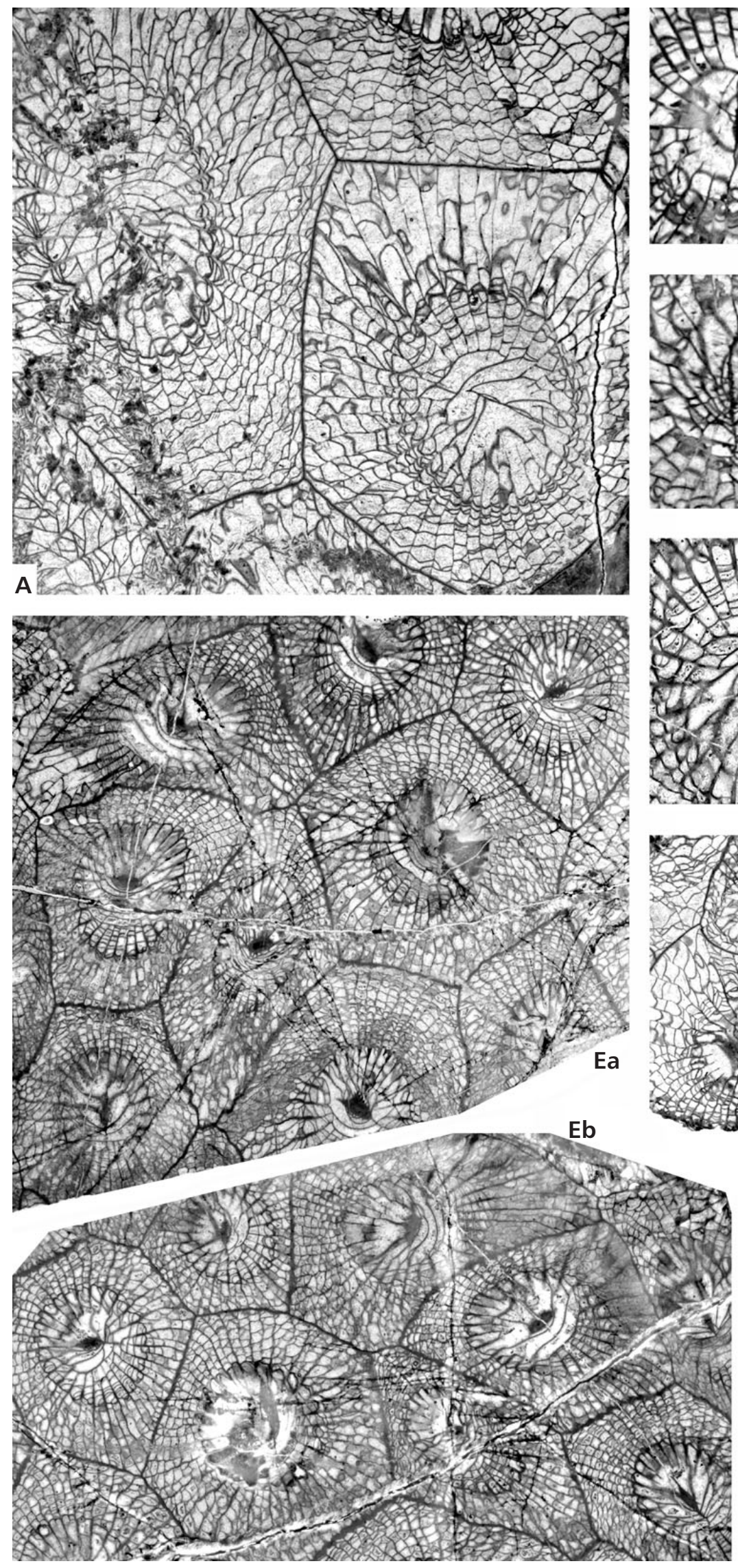

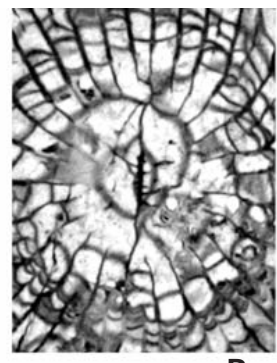

Ba
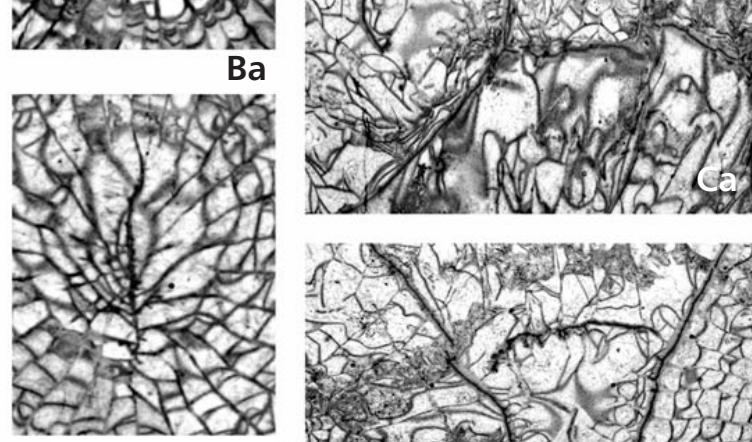

$\mathrm{Bb}$
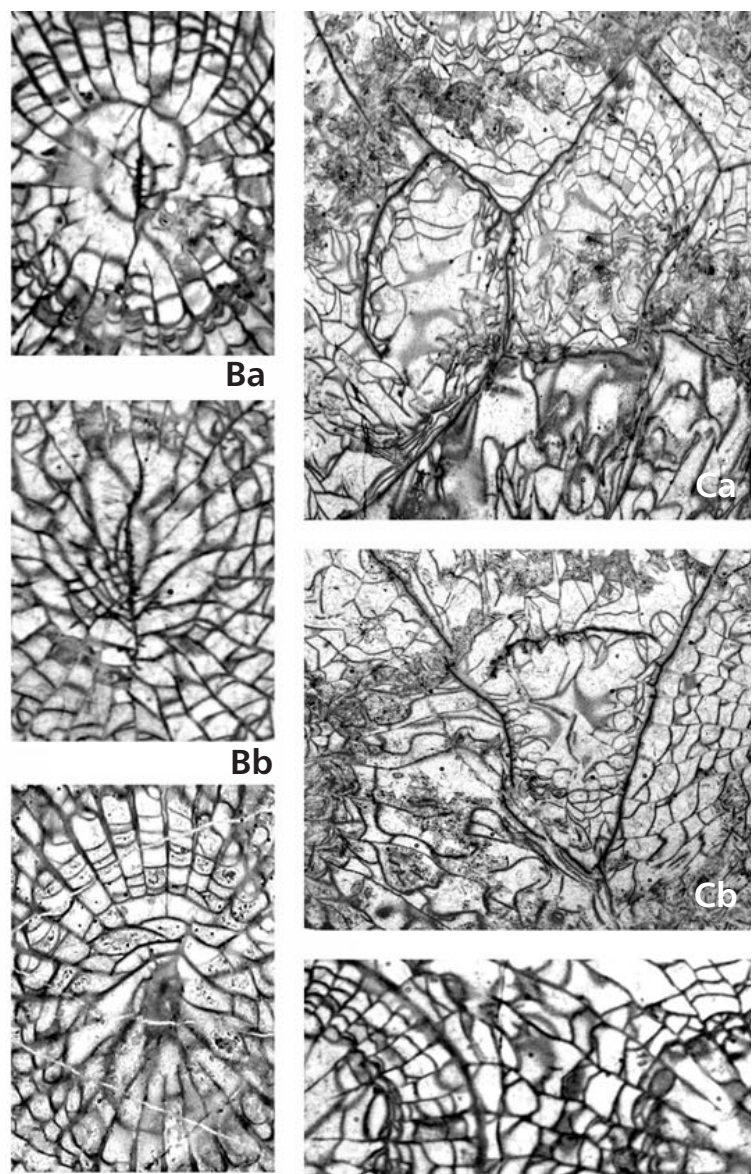

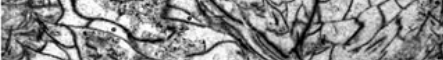

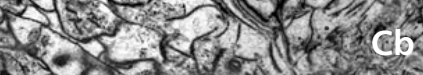
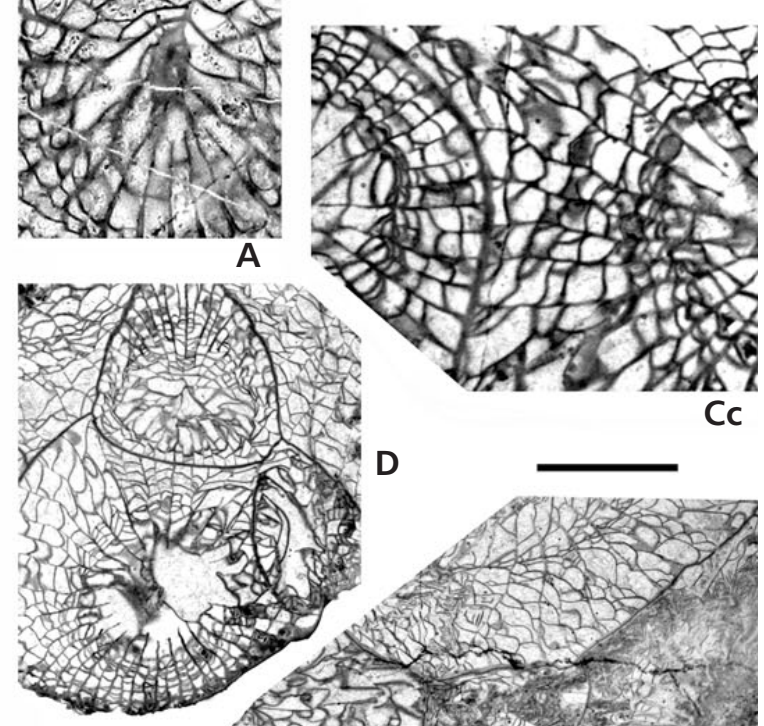

D

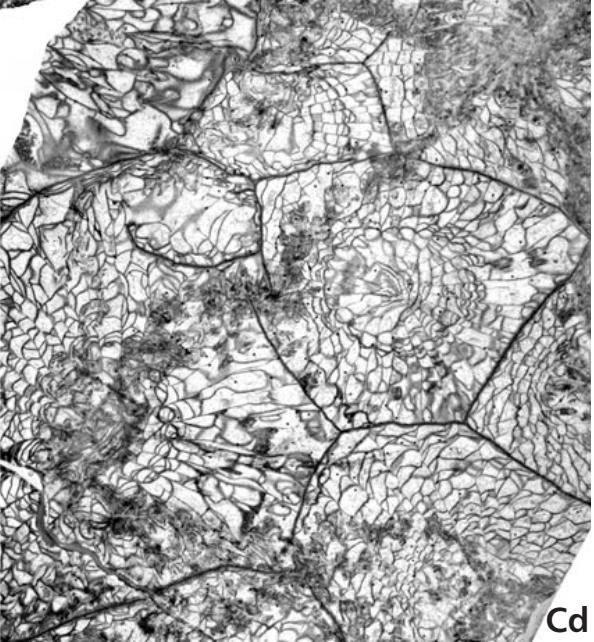



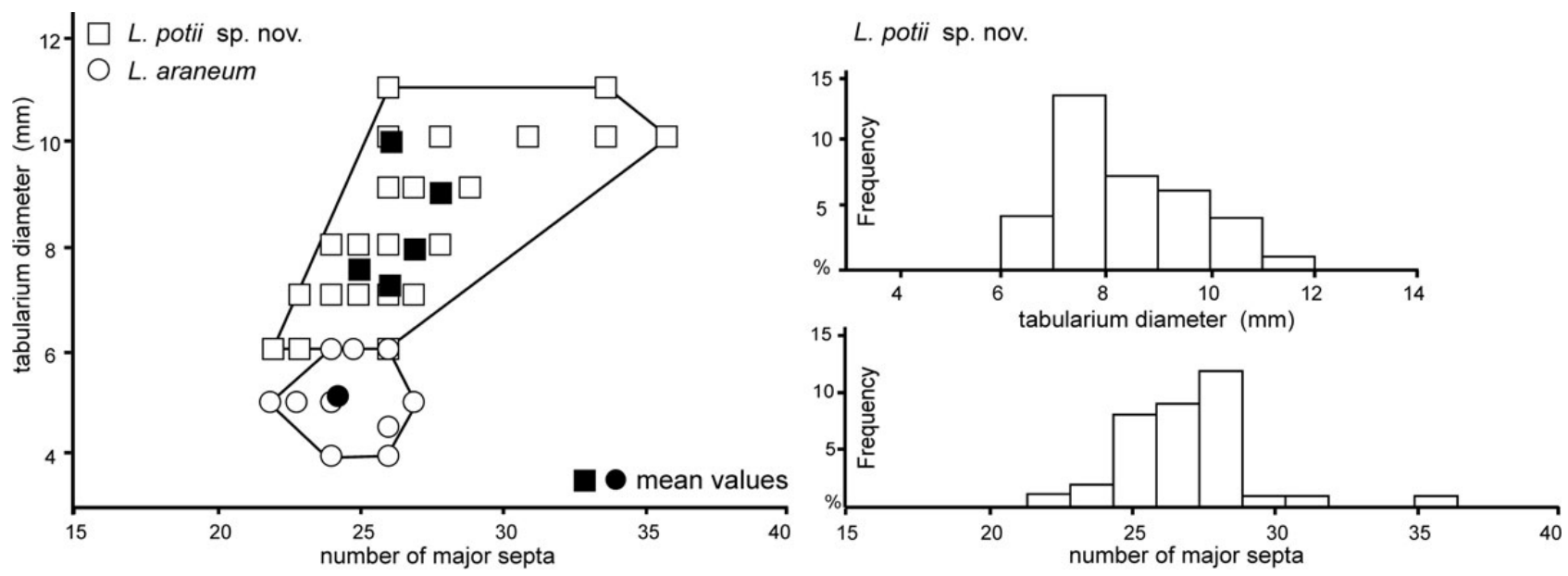

Figure 15. A - scatter diagram showing the number of septa plotted against tabularium diameter for Lithostrotion potii sp. nov. and Lithostrotion araneum (McCoy, 1844), based on 35 and 13 measurements, respectively. The mean values are given for each colony. $\bullet B-$ frequency histograms for the tabularium diameter and number of major septa of Lithostrotion potii sp. nov.

British Isles (Smith 1928), Nemistium appeared in the top of the late Viséan and is a guide of the Brigantian Biozone I of Mitchell (1989) and RC8 of Poty et al. (2006). Nemistium is also known in Nova Scotia (Poty 2002), Algerian Sahara (Semenoff-Tian-Chansky 1985) and Poland (Khoa 1977). The genus appears in the Russian Platform at least at the base of the upper Viséan (Dobroljubova 1958) but was described as Siphonodendron and Diphyphyllum (Poty 1984).

\section{Nemistium cf. affine (Fleming, 1828) \\ Figure $16 \mathrm{Ca}-\mathrm{g}$}

Material. - A single colony from a loose block in the Sayılı quarry close to the Kisla section.

Description. - Transverse section: The mean corallite diameter is $12.2 \mathrm{~mm}$ (maximum $17 \mathrm{~mm}$, Fig. 18). The tabularium is $9-13 \mathrm{~mm}$ large. There are 22-30 septa of both orders (maximum 36). The major septa extend up to the axis of the corallite. They are sinuous in the dissepimentarium but straight in the tabularium. They usually group in a cluster of 4-6 septa. The counter septum is longer and connected to the columella while the cardinal has the same length as the other septa. The minor septa are short (less than $1 / 3$ of the major ones) and restricted to the dissepimentarium. They are sinuous and thinner than the major ones. The columella is made of an irregular plate, undulating in the small-sized corallites, tortuous and reticulated in larger corallites (Fig. 16Cd). The dissepimentarium comprises 3-6 rows of concentric or herringbone interseptal dissepiments, irregular in width. The inner row is locally thickened. The external wall is irregular in thickness $(0.2$ to $0.5 \mathrm{~mm})$. Longitudinal section: The tabulae are in- complete, slightly convex and upturned towards the axial structure. The dissepiments are $1 \mathrm{~mm}$ large and 1-2 mm high, inclined at $60^{\circ}$ towards the tabularium. There are 10-14 tabulae and 12-15 dissepiments per centimetre height.

Increase. - This specimen shows the axial quadripartite parricidal increase typical of the genus (Fig. 16Cc). The corallites divide once they are $15 \mathrm{~mm}$ large. The first step of the division is the disappearance of the columella, immediately followed by the withdrawal of the septa. Once freed, the tabularium is rapidly occupied by a cruciform structure, which extends towards the periphery (Fig. 16Ca, b). This structure forms the external wall of the future offsets. The septa appear on these new walls before the corallites become completely individualized (Fig. 16Cc). The columella appears before the separation of the four new corallites.

Discussion. - All the generic characters of Nemistium Smith, 1928 are present in that specimen. However it differs from the type species $N$. edmondsi Smith, 1928 by a larger diameter (12 mm versus $9 \mathrm{~mm}$ in N. edmonsi), by a higher number of septa (28 versus 24 ) and shorter major septa. The dimensions and number of septa are similar to those of $N$. affine (Fleming, 1828) but the latter has longer septa. The Turkish specimen is also similar in dimensions to the corals described under the names Lithostrotion scoticum and L. dobroljubovae in the Viséan of the Russian Platform (Dobroljubova 1958) and with Nemistium sp. from the Algerian Bechard Basin (Semenoff-TianChansky 1985) but possesses longer septa.

Occurrence. - In the British Isles, N. affine (Flemings, 1828) appears relatively late in the late Warnantian (i.e. Brigantian Zone I of Mitchell 1989 and upper part of the 

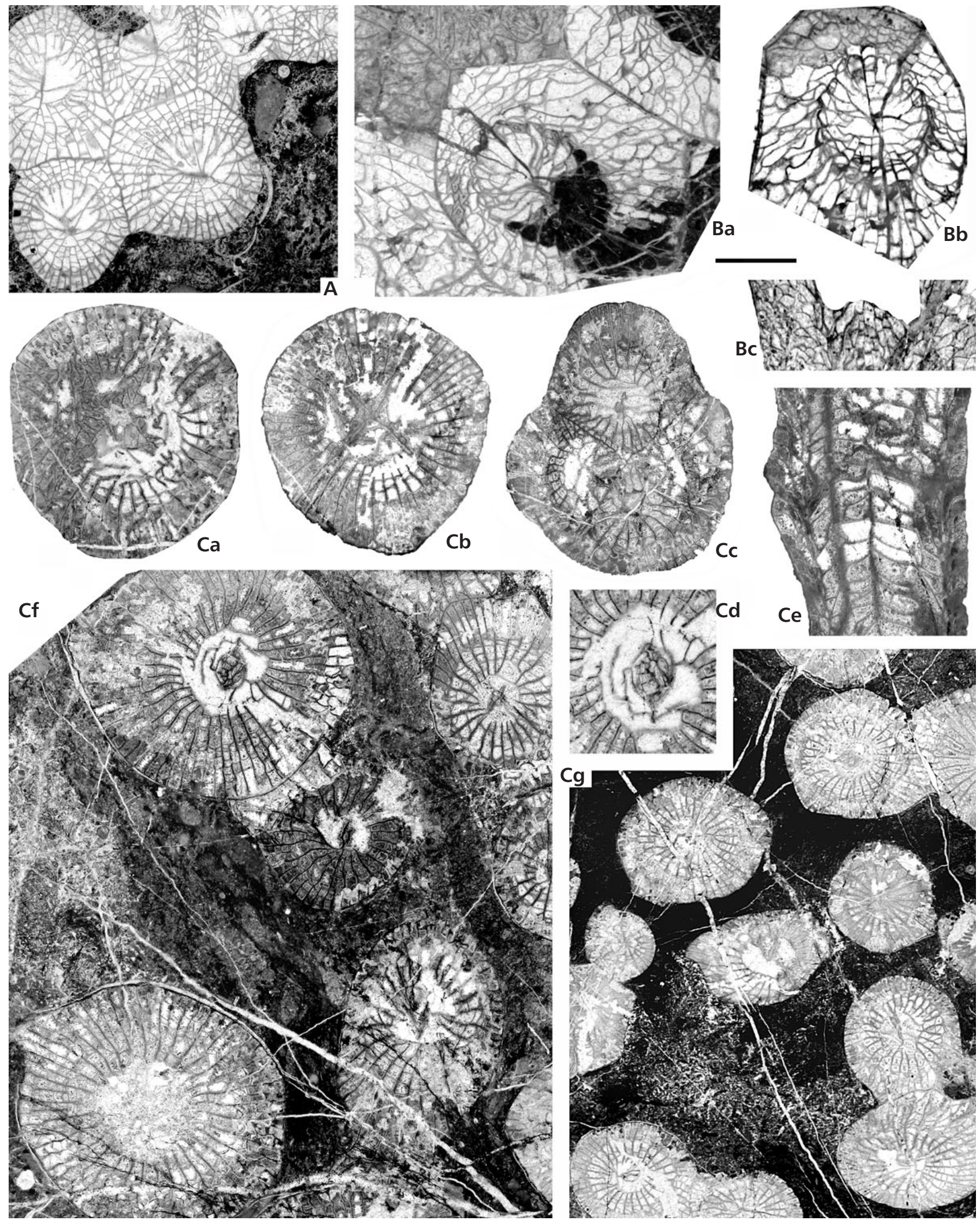

Figure 16. A - Lithostrotion vorticale (Parkinson, 1808), specimen K.12.6 from Kokaksu, TS (× 3)・ B - Lithostrotion sp., K.8.3.II from Kokaksu, Ba, $\mathrm{b}$ - successive TS $(\times 3), \mathrm{Bc}-\mathrm{LS}(\times 3) \cdot \bullet \mathrm{C}-$ Nemistium $\mathrm{cf}$. affine (Fleming, 1928), S.1.1 from Kisla, Ca-c - successive TS in offsetting corallites showing a quadripartite axial division $(\times 3), \mathrm{Cd}-$ close-up view of the axial structure, TS $(\times 4), \mathrm{Ce}-\mathrm{LS}(\times 3), \mathrm{Cf}-\mathrm{TS}(\times 3), \mathrm{Cg}-\mathrm{TS}(\times 2)$. All the specimens are Warnantian (Late Viséan). Scale bar equals $5 \mathrm{~mm}$ for A-Cc, Ce-Cf, equals $3.75 \mathrm{~mm}$ for $\mathrm{Cd}$ and equals $7.5 \mathrm{~mm}$ for $\mathrm{Cg}$. 


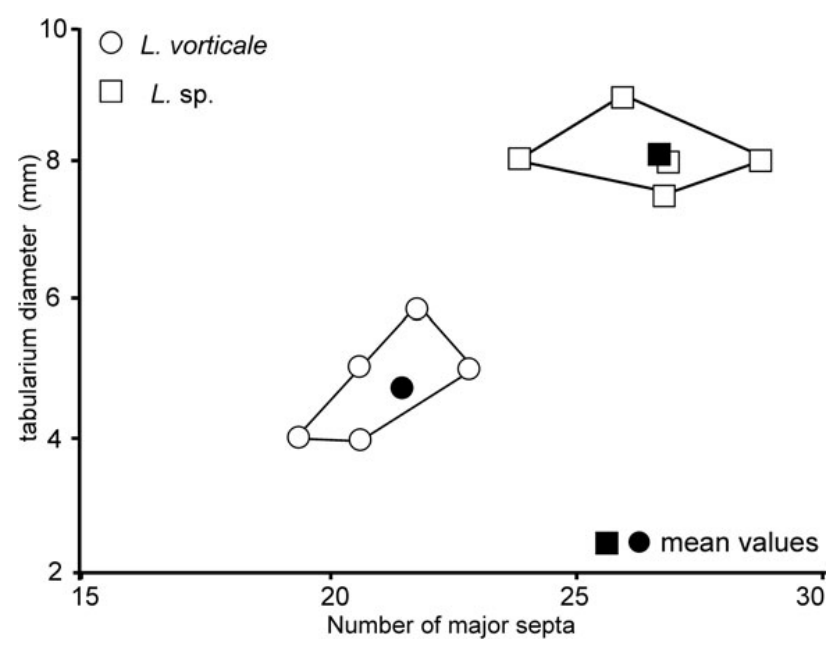

Figure 17. Scatter diagram showing the number of major septa plotted against tabularium diameter for Lithostrotion vorticale (Parkinson, 1808) and Lithostrotion sp., based on 20 and 5 measurements, respectively. The mean values are given for each colony.

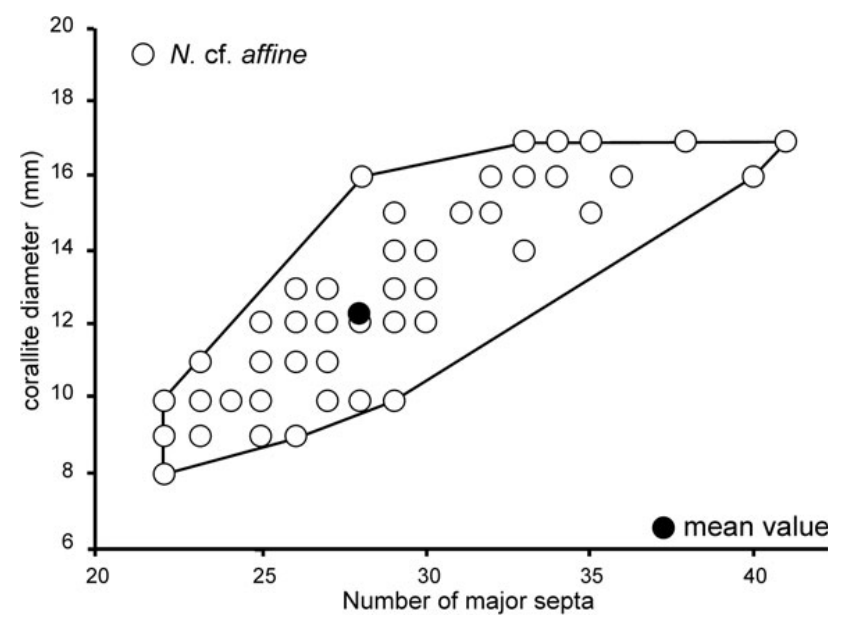

Figure 18. Scatter diagram showing the number of major septa plotted against corallite diameter for Nemistium cf. affine (Fleming, 1928), based on 60 measurements.

RC8 zone of Poty et al. 2006). The foraminifers associated with the specimen indicate the MFZ14 (lower Warnantian) but this age is questionable (see biostratigraphy section in the following discussions).

\section{Discussion}

\section{Biostratigraphy}

A tentative biostratigraphy, based on the vertical distribution of lithostrotionids and other colonial coral species along the four most continuous and fossiliferous sections is presented in Fig. 2. The stages and coral zones are from Poty et al. (2006) and Hance et al. (2011).
The base of the Moliniacian RC5 biozone is defined in W Europe by the first appearance of Siphonodendron ondulosum (Poty 1984). The first occurrence of the species was recorded in Kokaksu, Topluca and Süzek sections. S. ondulosum was not observed in Gökgöl, thus the base of RC5 is not well defined there. The classical subdivision into RC5 $\alpha-\beta-\gamma$ was not recognized, as the guide taxon Corphalia mosae Poty, $1975 \mathrm{~b}$ - is not present in Turkey. Nevertheless it was possible to subdivide the RC5 in two easily identifiable subzones. RC5A is defined by the assemblage Siphonodendron ondulosum, Dorlodotia briarti, Palaeosmilia murchisoni and Siphonodendron martini. This zone covers the whole RC5 $\alpha$ zone of W Europe. The second subzone - RC5B - displays an assemblage unknown in W Europe and dominated by Dorlodotia euxinensis, Ceriodotia bartinensis, Ceriodotia petalaxoides, Lithostrotion potii and Siphonodendron sp. A. The other taxa are species known earlier: S. ondulosum, S. martini, D. briarti, P. murchisoni and, occasionaly, S. irregulare, Clisiophyllum multiseptatum, Siphonophyllia sp. and a yet undescribed colonial amygdalophylloid genus. As stated above, the guide taxa of this second subzone are not present in W Europe and the correlation with the RC5 $\beta-\gamma$ of Poty et al. (2006) is not possible. The foraminifers associated with the RC5B coral fauna belongs to the MFZ11B as defined by Hance et al. (2011) based on the first appearance of primitive Pojarkovella together with the recently documented appearance of Conilidiscus ssp. (Okuyucu et al. 2013). The interval covered by the RC5B and MFZ11B corresponds in Belgium and British Isles, to unfossiliferous facies (mudstone, stromatolites, Poty \& Hance 2006) close to the $3^{\text {rd }}$ order sequence boundary number 6 of Hance et al. (2001) and the the gap associated to the boundary (including RC5 $\beta-\gamma$ ). RC5B should thus correspond to the falling stage system tract of sequence 6 or to the lowstand system tract of sequence 7. The facies (massive bioclastic grainstone and rudstone) are more compatible with a falling stage system tract than a lowstand, but this interpretation needs to be documented and discussed.

The RC6 biozone of Poty et al. (2006), characterized by S. martini, S. irregulare, L. araneum but without S. scaleberense and $S$. pauciradiale, has not been identified, as the faunal association overlying the RC5B subzone is already of Warnantian age. The Livian RC6 zone is consequently lacking and the corresponding $3^{\text {rd }}$-order sequences 7 and 8 (Hance et al. 2001) were probably not deposited or were eroded. Even if well developed in the Namur-Dinant Basin (Belgium), the Livian sequences are usually incomplete (as in Morocco, Aretz et al. 2013), display siliciclastic facies (as in SE China, Hance et al. 2011) or are lacking entirely (as in the Campine Basin, NE Belgium: Poty et al. 2001). This general under-development possibly means that the Livian transgression took place during a time of worldwide 


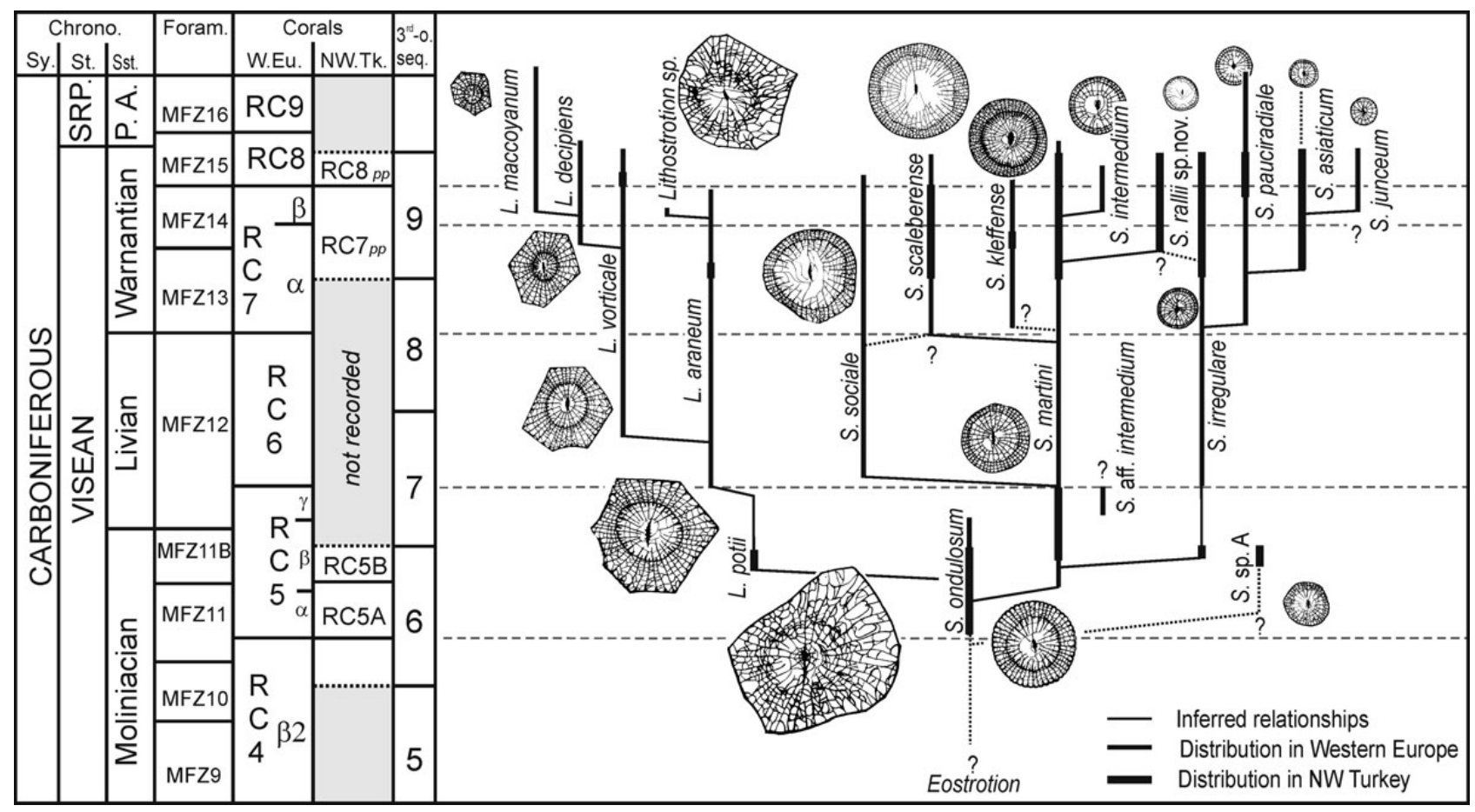

Figure 19. Stratigraphical distribution and inferred phyletic relationships between Lithostrotion and Siphonodendron species in W Europe and NW Turkey. Adapted from Poty (1984) with data from Poty (1993), Poty et al. (2006), Denayer et al. (2011) and unpublished data (Poty, pers. com.). Abbreviations: Chrono. - Chronostratigraphy, Sy. - System, St. - Stage, Sst. - substages, SRP. - Serpukhovian, P. A. - Pendleian-Arnsbergian, Foram. - foraminiferal biozones (MFZ) of Poty et al. (2006) and Hance et al. (2011), W. Eu. - W Europe, rugose corals biozones of Poty et al. (2006), NW Tk. - Poty's rugose coral zone adapted to NW Turkey, $3^{\text {rd }}$-o. seq. $-3^{\text {rd }}$-order sequences of Hance et al. (2001). Shaded time slices are not recorded in NW Turkey. Figured corals are not to scale.

low sea level (Wright \& Vanstone 2001). Consequently, its absence in NW Turkey is not surprising.

The RC7 biozone (lower Warnantian) is marked, in W Europe, by the appearance of the genera Dibunophyllum and Diphyphyllum but none of them is present in NW Turkey. This zone is thus here based on the occurrence of the common species Siphonodendron asiaticum and S. scaleberense, the latter being a marker of the RC7 in Europe. The other corals are S. martini, S. irregular, S. pauciradiale, $S$. rallii, S. kleffense and Lithostrotion araneum. The solitary rugose corals are represented by Aulophyllum fungites, Clisiophyllum aff. keyserlingi, Koninckophyllum interruptum, Siphonophyllia sibly and the long-ranging Palaeosmilia murchisoni. The occurrence of $A$. fungites, a guide taxa of the RC7 $\beta$ subzone, early in the Kokaksu section argues for a much reduced $\mathrm{RC} 7 \alpha$ subzone. For this reason and because no other taxa records the $\mathrm{RC} 7 \alpha-\beta$ boundary in the studied section, it is better to consider the RC7 zone as an undivided zone.

In the Zonguldak area (Kokaksu, Kisla and Gökgöl sections), the appearance of Palastraea konincki (Charles, 1933) defines the base of the RC8 subzone as the genus Palastraea McCoy, 1851 is a guide of the British Brigantian substage. The other taxa found in this zone are mainly those of the RC7 zone, but Lithostrotion vorticale and
Pseudozaphrentoides cf. juddi are also present. In Bartın, this zone is not recorded, the Namurian shales resting directly on limestone containing a RC7 coral assemblage.

\section{Phylogeny}

The phyletic lineage of the Lithostrotionidae proposed by Poty (1984), completed by datasets in Poty (1993) and Poty et al. (2006) can be emended by the Turkish material. Fig. 19 presents an updated version of Poty's model. Several remarks need to be made. i) Siphonodendron ondulosum presents a morphological variability higher than previously documented (e.g. Poty 1981, 1993; Javaux 1994). This variability includes specimens with a wide dissepimentarium that are very close to Lithostrotion potii corallites and probably evolved this way. ii) The paedomorphic lineage $S$. ondulosum - S. martini - S. irregulare - S. pauciradiale $-S$. junceum described by Poty $(1984,1993)$ is emended to include the species $S$. asiaticum as an intermediate (both morphological and stratigraphical) between $S$. pauciradiale and $S$. junceum. iii) The species $S$. rallii most probably evolved from $S$. martini by progenesis (see discussion of the species in the systematic section). Alternatively, $S$. rallii could have evolved from $S$. irregulare by 
Table 1. Summarized occurrences of Lithostrotion and Siphonodendron species in Eurasia and North Africa. Several areas are not taken in account because of their poorly known characters and/or poor quality of their documentation. Origin of the data: NW Turkey: this paper; S Turkey (Anatolides: Denayer 2012); British Isles: Hill (1938-1941), Somerville \& Rodríguez (2007); Nova Scotia: Lewis (1935) and Poty (2002), SW Spain: Rodríguez et al. (2002), Betic Cordillera: Herbig (1986); S France (Montagne Noire: Aretz 2002, Pyrénées: Perret \& Semenoff-Tian-Chansky 1971); Brittany: Vuillemin (1990); Belgium: Denayer et al. (2011); Morocco (Jerada: Aretz \& Herbig 2010, Adarouch: Said et al. 2013); Sahara: Semenoff-Tian-Chansky (1985), Aretz (2011), Aretz et al. (2013); Poland: Khoa (1977); Donets Basin: Vassiljuk (1960), Ogar (2010); Ural Mountains and Novaya Zemlya: Gorsky (1938, 1978); Russian Platform: Dobroljubova (1958); Kuznetsk: Fomichev (1931), Dobroljubova et al. (1966); Kazakhstan: Bykova (1966), Volkova (1941); Siberia and Omolon: Ivanowski (1967), Onoprienko (1976), Conil et al. (1982); S China and Thailand: Yü (1933), Fan et al. (2003), Lin et al. (2012), Fontaine et al. (1991).

\begin{tabular}{|c|c|c|c|c|c|c|c|c|c|c|c|c|c|c|c|c|c|c|}
\hline & 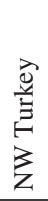 & $\begin{array}{l}\vec{d} \\
\stackrel{y}{\Xi} \\
\text { 告 }\end{array}$ & 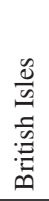 & $\begin{array}{l}\stackrel{\pi}{\Xi} \\
0 \\
\tilde{n} \\
\tilde{n} \\
0 \\
z\end{array}$ & 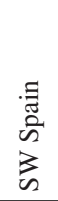 & 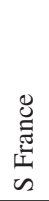 & 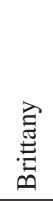 & 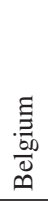 & $\begin{array}{l}0 \\
0 \\
0 \\
\dot{0} \\
\Sigma\end{array}$ & 点 & 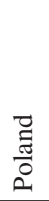 & $\begin{array}{l}\tilde{0} \\
\stackrel{0}{0}\end{array}$ & 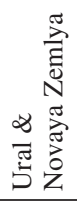 & 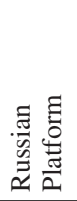 & 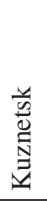 & 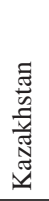 & 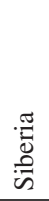 & $\begin{array}{l}\stackrel{\pi}{\Xi} \\
\text { 光 } \\
\sim\end{array}$ \\
\hline S. junceum & - & - & 1 & 1 & 1 & 1 & - & 1 & 1 & 1 & 1 & - & - & - & - & - & - & - \\
\hline S. asiaticum & 1 & - & - & - & - & - & - & - & - & - & - & 1 & - & - & 1 & 1 & - & 1 \\
\hline S. pauciradiale & 1 & 1 & 1 & 1 & 1 & 1 & - & 1 & 1 & 1 & 1 & 1 & 1 & - & - & - & 1 & 1 \\
\hline S. intermedium & - & cf. & 1 & 1 & 1 & 1 & - & 1 & 1 & - & - & - & - & - & - & - & - & - \\
\hline S. irregulare & 1 & 1 & 1 & 1 & 1 & 1 & - & 1 & 1 & 1 & 1 & 1 & 1 & 1 & - & 1 & - & 1 \\
\hline S. rallii & 1 & - & - & - & - & - & - & - & - & - & - & - & - & - & - & - & - & - \\
\hline S. martini & 1 & 1 & 1 & - & 1 & 1 & 1 & 1 & 1 & 1 & 1 & 1 & 1 & 1 & - & 1 & 1 & 1 \\
\hline S. sociale & - & - & 1 & - & 1 & - & - & 1 & 1 & - & - & - & - & - & - & - & - & - \\
\hline S. scaleberense & 1 & - & 1 & - & 1 & 1 & - & 1 & 1 & 1 & 1 & - & - & - & - & - & - & - \\
\hline S. kleffense & 1 & - & - & - & cf. & - & - & 1 & - & cf. & - & - & - & - & - & - & - & - \\
\hline S.ondulosum & 1 & - & 1 & - & - & - & - & 1 & - & - & - & cf. & - & - & - & - & 1 & - \\
\hline L. maccoyannum & - & 1 & 1 & - & 1 & 1 & - & 1 & 1 & 1 & 1 & 1 & - & 1 & - & 1 & - & 1 \\
\hline L. decipiens & - & 1 & 1 & - & 1 & 1 & - & 1 & 1 & 1 & 1 & - & 1 & 1 & - & - & 1 & 1 \\
\hline L. vorticale & 1 & - & 1 & - & 1 & - & cf. & 1 & 1 & 1 & - & 1 & 1 & 1 & - & - & - & cf. \\
\hline L. araneum & 1 & 1 & 1 & - & 1 & - & - & 1 & 1 & 1 & - & 1 & - & 1 & - & - & - & - \\
\hline L. potii & 1 & - & - & - & - & - & - & - & - & - & - & - & - & - & - & - & - & - \\
\hline Nemistium & 1 & - & 1 & 1 & 1 & 1 & - & - & - & 1 & 1 & - & 1 & 1 & - & 1 & - & - \\
\hline Diphyphyllum & - & - & 1 & - & 1 & - & - & 1 & 1 & 1 & 1 & 1 & 1 & 1 & 1 & - & - & 1 \\
\hline Orionastraea & - & - & 1 & - & - & - & - & - & - & - & - & - & 1 & 1 & 1 & - & - & 1 \\
\hline
\end{tabular}

hypermorphosis (Fig. 19). iv) While the lineage leading from $S$. ondulosum to $S$. junceum is quite clear and well documented, the evolutionary processes involved in the appearance of large species of Siphonodendron (S. sociale, S. kleffense, S. scaleberense) are less obvious. All of them possibly originated in $S$. martini but their relationships need to be documented. v) Lithostrotion originated in Siphonodendron as highlighted by Poty (1981, 1984, 1993), but L. araneum is not the oldest species of the genus as postulated by this author. The discovery of L. potii in the late Moliniacian pre-dates the appearance of the genus by at least 1.25 Ma (estimated duration of the gap between $3^{\text {rd }}$-order sequences of the lowstand of sequence 7, after Poty et al. 2013b). The evolution from Siphondendron ondulosum to Lithostrotion potii can be explained by a neotenic process (see discussion of the genus in the systematic section). vi) $L$. potii gave rise to $L$. araneum through progeny and the resulting paedomorphocline leads to $L$. vorticale, $L$. decipiens and L. maccoyanum as stated by Poty (1993). The species Siphonodendron sp. A, Siphonodendron aff. kleffense and Lithostrotion sp. are yet too poorly known to integrate them into the phyletic scheme.

\section{Palaeobiogeography}

Table 1 summarizes the occurrence of the species of Lithostrotion and Siphonodendron described in the present paper amongs the most well known areas bearing fossiliferous Viséan strata. The occurrences of the other genera (Nemistium, Diphyphyllum and Orionastraea) belonging to the Lithostrotionidae family are also provided. While some species ( $S$. pauciradiale, S. irregulare, S. martini) have a very wide geographic range, the others occur in a limited number of areas (S. sociale, S. kleffense, S. intermedium). The latters are good palaeogeographic markers. On the other hand, the first group have only an interest in biostratigraphy, even if their first appearance can be diachronous (Poty et al. 2011). Table 1 aims at a comparison between the considered areas and allows the report of some trends. One of them concerns the dual palaeogeographic distribution of the species $S$. junceum and S. asiaticum. All regions under consideration possess one or the other but never both species. $S$. junceum is the typical small-sized species in the Western Europe Province of Sando (1990) while $S$. asiaticum has a wide distribution through the 
Asian provinces (including Donets Basin and NW Turkey). This dual distribution can originate in the occurrence of both species in the same ecological niche. Considering NW Turkey, co-occurrences of Asian (e.g. S. asiaticum, but also Ceriodotia and Kwangsiphyllum - pers. unpub. data) and W European (e.g. S. kleffense, S. ondulosum, but also Zaphriphyllum and Bounophyllum - pers. unpublished data) taxa highlight the mixed character of the faunal association. Indeed, during the Lower Carboniferous times, the Istanbul-Zonguldak Zone was part of the southern margin of Baltica and was connected to the future Donets Basin (Stampfli et al. 2002, Moix et al. 2008). These areas were thus situated in a key position within the Palaeotethys Ocean, at the crossing between W European, E European and Asian provinces. This mixed trend is moreover observed in the foraminiferal assemblages (Dîl et al. 1976; Kalvoda 2002, 2003) of the Tournaisian and Viséan strata of Zonguldak.

\section{Conclusions}

The Viséan succession of Zonguldak and Bartın (NW Turkey) yielded an abundant and diversified coral fauna among which are many Lithostrotionidae. The three genera recorded are the fasciculate Siphonodendron and Nemistium and the cerioid Lithostrotion. Nemistium is represented by a single species: $N$. cf. affine but Siphonodendron has several species: Siphonodendron ondulosum ("Lophophyllum fraiponti" in Charles 1933), S. martini, S. irregulare, S. pauciradiale, S. asiaticum, S. scaleberense, S. kleffense, $S$. aff. kleffense, $S$. sp. A and the new species: $S$. rallii sp. nov. The cerioid species are Lithostrotion potii sp. nov., L. araneum, L. decipiens and L. sp. Lithostrotion potii sp. nov. is the oldest recorded species of the genus originated in subcerioid large corallites of Siphonodendron ondulosum in the latest Moliniacian. Together with species of the genera Dorlodotia and Ceriodotia and solitary rugose corals, the lithostrotionids demonstrate one more time their utility in biostratigraphy. The rugose corals RC5, RC7 and RC8 of Poty et al. (2006) were recognized in almost all the studied sections. The biozone RC6 is lacking due to the non-deposition or erosion of the Livian succession. This absence is also supported by foraminifers and sequence stratigraphic analysis but the latter will be described in a separate publication. The palaeogeographic distribution of the lithostrotionid corals highlights the mixed character of the Zonguldak and Bartın assemblages sharing taxa with European and Asian provinces

\section{Acknowledgements}

Demir Altıner is thanked for giving us the opportunity to visit and sample the Zonguldak area in 2008. Tezcan Çobanoğlu is thanked for his help in the field in the Bartın area in 2010-2011. Fieldwork and research were supported by a FRIA grant from the Belgian Fond National de la Recherche Scientifique (FNRS) and the University of Liège. The author thanks Luc Hance for his help on the determination of forams and discussion on biostratigraphy. The author is deeply indebted to Markus Aretz and Edouard Poty for fruitfull discussions on taxonomy and stratigraphy. They also criticized the early draft of this work. The manuscript has benefited from the review of Sergio Rodríguez and Ian Somerville. The latter is particularly thanked for the English improvement.

\section{References}

Aretz, M. 2002. Rugose corals and associated microfossils from the Brigantian (Mississippian) of Castelsec (Montagne Noire, southern France). Geobios 35, 187-200.

DOI 10.1016/S0016-6995(02)00018-9

Aretz, M. 2010. Rugose corals from the upper Viséan (Carboniferous) of the Jerada Massif (NE Morocco): taxonomy, biostratigraphy, facies and palaeobiogeography. Paläontologische Zeitschrift 84, 323-344. DOI 10.1007/s12542-009-0046-0

Aretz, M. 2011. Corals form the Carboniferous of central Sahara (Algeria): the collection "Marie Legrand-Blain". Geodiversitas 33, 581-624. DOI 10.5252/g2011n4a3

Aretz, M., Denayer, J. \& Mottequin, B. 2013. Preliminary data on Viséan (Carboniferous) corals and brachiopods from the strata between the Djebel Begaa and the Gara el Itima (Eastern Tafilalt, Morocco), 87-94. In Becker, R.T., El Hassani, A. \& TAHIRI, A. (eds) International Field Symposium "The Devonian and Lower Carboniferous of Northern Gondwana”. Document de l'Institut Scientifique, Rabat 27.

Aretz, M. \& Herbig, H.-G. 2010. Corals from the Upper Viséan of the southern Azrou-Khenifra Basin (Carboniferous, central Moroccan Meseta), 294-305. In KossovayA, O. \& SomerVILle, I. (eds) Proceedings of the $10^{\text {th }}$ International Symposium on Fossil Cnidaria and Porifera, Saint-Petersbourg, Russia. Palaeoworld 19.

Aretz, M. \& NudDS, J. 2005. The coral fauna of the Holkerian/Asbian boundary stratotype section (Carboniferous) at Little Asby Scar (Cumbria, England) and implications for the boundary. Stratigraphy 2(2), 167-190.

BAmBer, E.W. 1966. Type Lithostrotionid corals from the Mississippian of Western Canada. Bulletin of the Geological Survey of Canada 135, 1-28.

Byкоva, M.S. 1966. Carboniferous corals of Western Kazakhstan. 159 pp. Works of the Palaeontological Institute, Academy of Sciences of USSR, Moscow. [in Russian]

Charles, F. 1933. Contribution à l'étude des terrains paléozoïques de l'Anatolie du Nord-Ouest (Asie mineure). Mémoires in $4^{\circ}$ de la Société géologique de Belgique 7 , 54-152.

Conil, R., Poty, E., Simakov, K.V. \& Streel, M. 1982. Foraminifères, spores et coraux du Famennien supérieur et du Dinantien du massif de l'Omolon (Extrême-Orient soviétique). Annales de la Société géologique de Belgique 105, 145-160. 
Cózar, P., Somerville, I.D., Aretz, M. \& Herbig, H.-G. 2005. Biostratigraphic dating of the Bricklieve Limestone Formation (NW-Ireland) using foraminifers, calcareous algae and rugose corals. Irish Journal of Earth Sciences 23, 1-23.

DenAyer, J. 2011. Dorlodotia and related genera (Rugosa) from the Viséan (Mississipian; Carboniferous) of Zonguldak and Bartin (North-Western Turkey). Palaeontology 54, 1435-1454. DOI 10.1111/j.1475-4983.2011.01104.x

DenAYER, J. 2012. Corals of the upper Viséan microbial-spongebryozoan-coral bioherm and related strata of Kongul Yayla (Taurides, S Turkey), 317-328. In Denayer, J., Aretz, M. \& Pоту, E. (eds) Proceedings of the $11^{\text {th }}$ International Symposium on Fossil Cnidaria and Porifera, Liège, Belgium, 2011. Geologica Belgica 15(4).

Denayer, J., Poty, E. \& Aretz, M. 2011. Uppermost Devonian and Dinantian rugose corals from Southern Belgium and surrounding areas, 151-201. In ARETZ, M. \& Pоту, E. (eds) $11^{\text {th }}$ International Symposium on Fossil Cnidaria and Porifera, Liège, 19-29 August, 2011, Field-Guides, Kölner Forum für Palaöntologie und Geologie 20.

Dîl, N. \& Konyali, Y. 1978. Carboniferous of Zonguldak area, IUGS Subcommission on Carboniferous stratigraphy, Field Excursion on the Carboniferous of Turkey Guidebook. 25 pp. Ankara.

Dîl, N., Termier, G., Termier, H. \& Vachard, D. 1976. Contribution à l'étude stratigraphique et paléontologique du Viséen supérieur et du Namurien inférieur du Bassin Houiller de Zonguldak (nord-ouest de la Turquie). Annales de la Société géologique de Belgique 99, 401-449.

Dobroljubova, T.A. 1958. Lower Carboniferous colonial tetracorals from the Russian Platform. Works of the Palaeontological Institute, Academy of Sciences of USSR 70, 1-226. [in Russian]

Dobroljubova, T.A., Kabakovitsh, N.V. \& Sayutina, T.A. 1966. Lower Carboniferous corals of the Kuznetsk Basin. Trudy Academy of Sciences Ukraina USSR 111, 1-92. [in Russian]

ERENTÖZ, C. 1966. Contribution à la stratigraphie de la Turquie. Bulletin of the Mineral Research and Exploration Institute of Turkey (MTA Bulletin) 66-1, 2-22.

FAN, Y. 1978. Rugose corals, 149-209. In ChENGdu Institute OF Geology and Mineral Resources (ed.) The paleontological atlas of southwest China, Sichuan. Geological Publishing House, Beijing. [in Chinese]

Fan, Y., Yu, X., He, Y., PAn, Y., Li, X., Wang, F., TANG, D., Chen, S., Zhao, P. \& Liu, J. 2003. The Late Palaeozoic rugose corals of Xizang (Tibet) and adjacent regions and their palaeobiogeography. 679 pp. Hunan Science and Technology Press, Beijing.

Fedorowski, J. 1971. Aulophyllidae (Tetracoralla) from the Upper Viséan of Sudetes and Holy Cross Mountains. Palaeontologica Polonica 15, 203-217.

Fedorowski, J. 2008. Early Carboniferous Chinese and Australian "Siphonodendron" (Anthozoa, Rugosa): ecological and geographical influence on taxonomy. Geologos 14(1), 3-17.

Fedorowski, J. \& BAmber, E.W. 2007. Remarks on lithostrotionid phylogeny in western North America and W Europe, 251-273. In Hubmann, B. \& Piller, W.E. (eds) Fossil
Corals and Sponges, Proceedings of the $9^{\text {th }}$ International Symposium on Fossil Cnidaria and Porifera, Graz, 2003. Schrifenreihe der Erdwissenschaftlichen Kommissionen 17.

Fleming, J. 1828. A history of British animals. 565 pp. Bell \& Bradfute Ed., Edinburgh.

FomitcheV, V.D. 1931. New data on Lower Carboniferous corals of the Kuznetsk Basin. Transactions of the Geological and Prospecting Service of USSR 49, 1-49. [in Russian]

Fontaine, H., Suteethorn, V. \& Jongkanjanasoontorn, Y. 1991. Carbonifeorus corals of Thailand. Committee for coordination of joint prospecting for mineral resources in Asian offshore areas 22, 1-82.

GönCÜOĞLU, M.C., Dirik, K. \& Kozlu, H. 1997. Pre-alpine and alpine terranes in Turkey: explanatory notes to the terrane map of Turkey. Annales géologiques des Pays Helleniques 37, 515-536.

GöRÜR, N. \& TÜYSÜZ, O. 2001. Cretaceous to Miocene palaeogeographic evolution of Turkey: implications for hydrocarbon potential. Journal of Petroleum Geology 24, 119-146. DOI 10.1111/j.1747-5457.2001.tb00664.x

GoRsky, I. 1938. Carboniferous corals from Novaya Zemlya, 1-221. In Nalivkin, D.V. (ed.) Paleontology of the Soviet Arctic, part II. Chief administration of the Northern Sea route Arctic Institute of the USSR. [in Russian]

GoRsky, I. 1978. Middle Carboniferous corals of the Western Slope of Urals. 222 pp. Academy of Sciences of the USSR, Moscow. [in Russian]

Hance, L., Hou, H.-F. \& Vachard, D. 2011. Upper Famennian to Viséan Foraminifers and some carbonate Microproblematica from South China. 359 pp. Geological Publishing House, Beijing.

Hance, L., Poty, E. \& Devuyst, F.-X. 2001. Stratigraphie séquentielle du Dinantien type (Belgique) et corrélation avec le Nord de la France (Boulonnais, Avesnois). Bulletin de la Société géologique de France 172, 411-426. DOI 10.2113/172.4.411

Herbig, H.-G. 1986. Rugosa und Heterocorallia aus OberviséGeröllen der Marbella-Formation (Betische Kordilliere, Südspanien). Paläontologische Zeitschrift 60, 189-225. DOI 10.1007/BF02985668

HiLl, D. 1934. The Lower Carboniferous corals of Australia. Proceedings of the Royal Society of Queensland 45(12), 63-115.

HiLl, D. 1938-1941. A monograph on the Carboniferous rugose corals of Scotland. Palaeontographical Society 1938-1941, $1-213$.

HiLl, D. 1981. Coelenterata; Supplement 1, Rugosa and Tabulata, 1-762. In TEICHERT, C. (ed.) Treatise on invertebrate paleontology. Geological Society of America \& University of Kansas, Boulder \& Lawrence.

HoșGÖRMEZ, H. 2007. Origin and secondary alteration of coalbed and adjacent rock gases in the Zonguldak Basin, western Black Sea, Turkey. Geochemical Journal 41, 201-211. DOI 10.2343/geochemj.41.201

Howel, E.J. 1938. Rugose corals from the Mid-Avonian Limestones of West Glamorgan. The Annals and Magazine of Natural History 11(1), 1-22. DOI 10.1080/00222933808526734

Ivanowski, A.B. 1967. Study on Lower Carboniferous rugose corals. 97 pp. Works of the Palaeontological Institute, Academy of Sciences of USSR, Moscow. [in Russian] 
JAVAuX, E. 1994. Paleoecology of rugose corals in the Neffe Formation (Middle Viséan) of Belgium. Courier Forschunginstitut Senckenberg 172, 127-139.

JuLL, R.K. 1965. Corallum increase in Lithostrotion. Palaeontology 8(2), 204-225.

JuLL, R.K. 1974. The Rugose Corals Lithostrotion and Orionastraea from Lower Carboniferous (Viséan) beds in Queensland. Proceedings of the Royal Society of Queensland 85, 57-76.

Kalvoda, J. 2002. Late Devonian-Early Carboniferous Foraminiferal Fauna: Zonations, evolutionary trends, paleobiogeography and tectonic implications. 213 pp. Masaryk University Press, Brno.

Kalvoda, J. 2003. Carboniferous foraminifera paleobiogeography in Turkey and its implications for plate tectonic reconstructions. Rivista Italiana di Paleontologia e Stratigrafia 109(2), 255-266.

Kato, M. 1971. J. Fleming's species of British Lower Carboniferous corals. Transaction and Proceedings of the Paleontological Society of Japan 81, 1-10.

KноA, N.D. 1977. Carboniferous Rugosa and Heterocorallia from boreholes in the Lublin region (Poland). Acta Palaeontologica Polonica 22, 301-404.

LEwIS, H.P. 1935. The Lower Carboniferous corals of Nova Scotia. Annals and Magazine of Natural History 16, 118-142. DOI 10.1080/00222933508655027

Lin, B. \& Rodriguez, S. 1993. Estudio de los corales rugosos del Carbonifero inferior de Mahai, Provincia de Qinghai, Noroeste de China. Boletín del Real Societad Española de Historia Natural (seccion Geología) 88(1/4), 17-55.

Lin, W., WANG, X., Poty, E. \& Aretz, M. 2012. Late Viséan to Early Serpukhovian rugose corals from the Yashui Section, Guizhou, South China, 329-339. In DenAYer, J., Aretz, M. \& Pоту, E. (eds) Proceedings of the $11^{\text {th }}$ International Symposium on Fossil Cnidaria and Porifera, Liège, Belgium. Geologica Belgica 15(4).

MAMET, B.L. 1973. Foraminiferal biostratigraphy of the Lower Carboniferous Trakya and Heybeliada Formations, Istanbul region, Istanbul, 137-143. In KAYA, O. (ed.) Paleozoic of Istanbul. Ege Üniversitesi Fen Fakültesi Kitaplar Serisi 40.

McCoy, F. 1844. A synopsis of the characters of the Carboniferous limestone fossils of Ireland. 207 pp. University Press, Dublin. DOI 10.5962/bhl.title.11559

McCoy, F. 1849. On some new genera of Palaeozoic Corals and Foraminifera. Annals and Magazine of Natural History, serie 2(3), 1-20, 119-136.

McCoy, F. 1851. Description of the British Palaeozoic fossils in the Geological Museum of the University of Cambridge. 502 pp. University Press, Cambridge.

Milne-Edwards, H. \& Haime, J. 1850-1855. A monograph of the British fossil corals. 1-71 pp. (1850), 147-210 pp. (1852), 211-244 pp. (1853), 245-299 pp. (1855). Palaeontographic Society Monograph, London.

Milne-Edwards, H. \& Haime, J. 1851. Monographie des Polypiérites fossiles des terrains paléozoïques, précédée d'un tableau général de la classification des Polypes. Archives $d u$ Musée d'Histoire naturelle de Paris 5, 1-502.

Minato, M. 1955. Japanese Carboniferous and Permian corals. Journal of the Faculty of Science, Hokkaido University, Series IV: Geology and Mineralogy 9-2, 1-202.
Mitchell, M. 1989. Biostratigraphy of Viséan (Dinantian) rugose coral faunas of Britain. Proceedings of the Yorkshire Geological Society 47, 233-247.

DOI 10.1144/pygs.47.3.233

Moix, P., Beccaletto, L., Kozur, H.W., Hochard, C., Rosselet, F. \& STAMPfli, G.M. 2008. A new classification of the Turkish terranes and sutures and its implication for the paleotectonic history of the region. Tectonophysics 451, 7-39.

DOI 10.1016/j.tecto.2007.11.044

Nudds, J.R. 1979. Coloniality in the Lithostrotionidae (Rugosa), Biology and systematics of colonial organisms, 173-192. In LARWOOD, G. \& Rosen, B.R. (eds) Biology and Systematics of Colonial Organisms. Academic Press, London.

NuDDS, J.R. 1993. Siphonodendron and Dorlodotia: paedomorphic evolution in Carboniferous rugose corals? Courrier Forschunginstitut Seckenberg 164, 127-130.

NudDS, J.R. 1999. A new Carboniferous rugose coral genus from northern England. Palaeontology 42, 223-229.

DOI 10.1111/1475-4983.00071

NudDS, J.R. \& SomervilLE, I.D. 1987. Two new species of Siphonodendron (Rugosa) from the Viséan of the British Isles. Proceedings of the Yorkshire Geological Society 46, 293-300. DOI 10.1144/pygs.46.4.293

OGAR, V. 2008. New species of lithostrotionid (rugose coral) from the Lower Viséan of Tian-Shan. Ukrainian Geologist Magazine 2008(3), 92-97.

OGAR, V. 2010. New data on the Carboniferous corals of the Donets Basin, 284-293. In Kossovaya, O. \& Somerville, I. (eds) Proceedings of the $10^{\text {th }}$ International Symposium on Fossil Cnidaria and Porifera. Palaeoworld 19(4).

Окау, A.I. 2008. Geology of Turkey: a synopsis. Anschnitt 21, $19-42$.

OкAy, A.I., SAtiR, M. \& Siebel, W. 2006. Pre-Alpide Palaeozoic and Mesozoic orogenic events in the Eastern Mediterranean region, 389-405. In Gee, D.G. \& StePhenson, R.A. (eds) European Lithosphere Dynamics. Geological Society of London, Special Publication 32.

Okuyucu, C., Vachard, D. \& GönCÜOĞLu, M.C. 2013. Refinements in biostratigraphy of the foraminiferal zone MFZ11 (late early Viséan, Mississippian) in the Cebeciköy Limestone (Istanbul Terrane, NW Turkey) and palaeogeographic implications. Bulletin of Geosciences 88(3), 621-645.

DOI 10.3140/bull.geosci.1387

ONOPRIENKo, Y. 1976. Early Carboniferous colonial rugose corals from the North-East of USSR, 5-34. In GRAMM, M.N. (ed.) Morphology and systematics of Soviet Far-East Fossil Invertebrates. Institute of Biology and Pedology Far-East Science Center, Academy of Sciences of the USSR, Vladivostok.

D'ORBigny, A. 1850. Prodrôme de paléontologie stratigraphique universelle des animaux mollusques et rayonnés. 349 pp. Ed. Masson, Paris.

D'Orbigny, A. 1852. Cours élémentaire de paléontologie et de géologie stratigraphique. 382 pp. Ed. Masson, Paris.

ÖzGÜL, N. 2012. Stratigraphy and some structural features of the Istanbul Palaeozoic. Turkish Journal of Earth Sciences 21, 817-866.

Paeckelmann, W. 1938. Neue Beiträge zur Kenntnis der Geologie, Paläontologie und Petrographie der Umgegend von 
Konstantinopel. Abhandlungen Preussisches Geologisches Landesamtes 186, 202.

PARKInSON, J. 1808. Organic remains of a former world. 286 pp. J. Robson, London.

Perret, M.-F. \& Semenoff-Tian-Chansky, P. 1971. Coralliaires des calcaires carbonifères d'Ardengost (Hautes-Pyrénées). Bulletin de la Société d'histoire naturelle de Toulouse 107(3-4), 567-594.

PHILLIPS, J. 1836. Illustration of the geology of Yorkshire, part II: the Mountain Limestome district. 253 pp. Ed. Murray, London.

PicKeTt, J. 1966. Lower Carboniferous coral faunas from the New England District of New South Wales. Memoirs of the Geological Survey of New South Wales, Palaeontology 15, $1-38$.

Pоту, E. 1975a. Contribution à l'étude des genres Lithostrotion et Siphonodendron du Viséen moyen belge. Annales de la Société géologique de Belgique 98-1, 75-90.

Pоту, E. 1975b. Un nouveau Tétracoralliaire du Viséen moyen de la Belgique: Corphalia mosae gen. et sp. nov. Annales de la Société géologique de Belgique 98, 111-121.

Pоту, E. 1981. Recherches sur les Tétracoralliaires et les Hétérocoralliaires du Viséen de la Belgique. Mededelingen Rijks Geologische Dienst 35-1, 1-161.

Pоту, E. 1984. An evolutionary pattern for the W European Lithostrotionidae. Palaeontographica Americana 54, 465-469.

Роту, E. 1993. Heterochronic processes in some Lower Carboniferous rugose corals. Courier Forschunginstitut Senckenberg $164,141-152$.

Pоту, E. 2002. Stratigraphy and paleobiogeography of Carboniferous rugose corals of Nova Scotia, 580-587. In HiLLs, L.V., Henderson, C.M. \& BAmber, E.W. (eds) Carboniferous and Permian of the World. Canadian Society of Petroleum Geologists 19.

Pоту, E. 2010. Morphological limitation to the diversification of the rugose and tabulate corals, 389-400. In Kossovaya, O. \& Somerville, I.D. (eds) Proceedings of the $10^{\text {th }}$ International Symosium on Fossil Cnidaria and Porifera, Saint-Petersburg, 2007. Palaeoworld 19.

Poty, E., Aretz, M. \& Hance, L. 2013a. Belgian substages as a basis for an international division of the Tournaisian and Viséan. Geological Magazine 151(2), 229-243. DOI 10.1017/S0016756813000587

Poty, E., AretZ, M. \& XU, S. 2011. A comparison of Mississippian colonial rugose corals from Western Europe and South China, 135-136. In Aretz, M., Delculée, S., Denayer, J. \& Poty, E. (eds) $11^{\text {th }}$ International Symposium on Fossil Cnidaria and Porifera, Liège, Belgium, Abstract volume. Kölner Forum für Geologie und Paläontologie 19.

Poty, E., Devuyst, F.-X. \& Hance, L. 2006. Upper Devonian and Mississippian foraminiferal and rugose coral zonations of Belgium and northern France: a tool for Eurasian correlations. Geological Magazine 143, 829-857.

DOI 10.1017/S0016756806002457

Poty, E. \& Hance, L. 2006. Livian. Geologica Belgica 9(1-2), $133-138$.

Poty, E., Hance, L., Lees, A. \& Hennebert, M. 2001. Dinantian lithostratigraphic units (Belgium). Geologica Belgica 4, 69-94.
Poty, E. \& Hannay, D. 1994. Stratigraphy of rugose corals in the Dinantian of the Boulonnais (France). Mémoires de l'Institut géologique de l'Université catholique de Louvain 35, 51-82.

Poty, E., Mottequin, B. \& Denayer, J. 2013b. An attempt of time calibration of the Lower Tournaisian (Hastarian substage) based on orbitally forced sequences, 105-107. In EL Hassani, M., Becker, R.T. \& TAhiri, A. (eds) Subcommission on Devonian Stratigraphy, International Field Symposium: "The Devonian and Lower Carboniferous of northern Gondwana”, Ouarzazate, Morocco. Document de l'Institut de Rabat 26 .

Ralli, G. 1895. Le Bassin Houiller d'Héraclée. Annales de la Société géologique de Belgique 23, 151-267.

Rodríguez, S., Hernando, J.M. \& Rodríguez-Curt, L. 2002. Estudio de los corales lithostrotiónidos del Viseense (Misisipiense) de la Unidad de la Sierra del Castillo (Córdoba, Espana). Revista Española de Paleontología 17, 13-36.

RodrígueZ, S. \& SAID, I. 2009. Descriptión de los corales rugosos del Viseense superior de Pennaroya-Pueblonuevo (Cordoba) y El Casar (Badajoz). Coloquios de Paleontología 59, 7-27.

Rodríguez, S. \& Somerville, I. 2007. Comparisons of rugose corals from the Upper Viséan of SW Spain and Ireland: implications for improved resolution in late Mississippian coral biostratigraphy, 275-305. In Hubmann, B. \& Piller, W.E. (eds) Fossil Corals and Sponges, Proceedings of the $9^{\text {th }}$ International Symposium on Fossil Cnidaria and Porifera, Graz, 2003. Schrifenreihe der Erdwissenschaftlichen Kommissionen 17.

Rodríguez, S., Somerville, I.D., SAid, I. \& Cózar, P. 2012. Late Viseéan coral fringing reef at Tiouinine (Morocco): implications for the role of rugose corals as building organisms in the Mississippian. Geological Journal 47, 462-476. DOI $10.1002 /$ gj. 2452

Rodríguez, S., Somerville, I., SAID, I. \& Cozar, P. 2013. Mississippian-like rugose corals from a Bashkirian biostrome in the Tindouf Basin, S. Morocco. Spanish Journal of Palaeontology 28(2), 255-284.

SAid, I., Berkhli, M. \& Rodriguez, S. 2007. Preliminary data on the coral distribution in the Upper Viséan (Mississippian) succession from Adarouch area (NE Central Morroco), 353-363. In Hubmann, B. \& Piller, W.E. (eds) Fossil Corals and Sponges, Proceedings of the $9^{\text {th }}$ International Symposium on Fossil Cnidaria and Porifera, Graz, 2003, Schrifenreihe der Erdwissenschaftlichen Kommissionen 17.

SAid, I., Somerville, I., Rodríguez, S. \& Cozar, P. 2013. Mississippian coral assemblages from the Khenifra area, central Morocco: biostratigraphy, biofacies, palaeoecology and palaeobiogeography. Gondwana Research 23, 367-379.

DOI 10.1016/j.gr.2012.04.008

SANDO, W.J. 1965. Revision of some Paleozoic Coral species from the Western United States. Geological Survey Professional Paper 503-E, 1-38.

SAndo, W.J. 1970. Corals, 257-343. In McKee, D. \& GutschNICK, R. (eds) History of Redwall Limestone of Northern Arizona. Geological Society of America Bulletin 114.

SANDO, W.J. 1990. Global Mississippian coral zonation. Courier Forschungsinstitut Senckenberg 130, 173-187.

SCHINDEWOLF, O.H. 1928. Prinzipienfragen der biologischen Systematik. Paläontologische Zeitschrift 9, 122-169. DOI 10.1007/BF03041886 
Scrutton, C.T. 1983. New offset-associated structures in some Carboniferous rugose corals. Lethaia 16, 129-144. DOI 10.1111/j.1502-3931.1983.tb01709.x

Semenoff-Tian-Chansky, P. 1985. Corals, 374-381. In Wagner, R.H., WinkLer-Prins, C.F. \& Granados, L.F. (eds) The Carboniferous of the world, II: Australia, Indian subcontinent, South Africa, South America and North Africa, Instituto Geologico y Minero de Espańa Empresa nacional adaro de investigaciones mineras.

Semenoff-Tian-Chansky, P. \& Nudds, J. 1979. Revision de quelques espèces de Lithostrotion des îles britanniques décrites par Milne-Edwards \& Haime (Tétracoralliaires carbonifères). Bulletin du Muséum national d'histoire naturelle de Paris, section C3, 245-283.

Sмiтh, S. 1916. Aulina rotiformis, gen. et sp. nov., Phillipsastrcea hennahi (Lonsdale), and Orionastraea, gen. nov. Quarterly Journal of the Geological Society 72(1-4), 280-307. DOI 10.1144/GSL.JGS.1916.072.01-04.14

Smith, S. 1928. The Carboniferous coral Nemistium edmondsi, gen. et sp. nov. Annals and Magazine of the Natural History Society 10, 112-120. DOI 10.1080/00222932808672752

Somerville, I.D. \& Rodríguez, S. 2007. Rugose coral associations from the Upper Viséan of Ireland, Britain and SW Spain, 329-351. In Hubmann, B. \& Piller, W.E. (eds) Fossil Corals and Sponges. Proceedings of the $9^{\text {th }}$ International Symposium on Fossil Cnidaria and Porifera, Graz, 2003. Schriftenreihe der Erdwissenschaftlichen Kommissionen 17.

Somerville, I.D., Rodríguez, S., SAid, I. \& Cozar, P. 2012. Mississippian coral assemblages from Tabainout mud-mound complex, Khenifra area, Central Morocco, 308-316. In Denayer, J., Aretz, M. \& Poty, E. (eds) Proceedings of the $11^{\text {th }}$ International Symposium on Fossil Cnidaria and Porifera, Liège, Belgium Geologica Belgica 15(4).

Somerville, I.D. \& Strank, A.R.E. 1984. Discovery of Arundian and Holkerian faunas from a Dinantian platform succession in North Wales. Geological Journal 19(2), 85-104. DOI 10.1002/gj.3350190202

Stampfli, G., Von Raumer, J.F. \& Borel, G.D. 2002. Paleozoic evolution of pre-Variscan terranes: From Gondwana to the Variscan collision, 263-280. In MARTINEZ-CATALÀn, J.R., HATCHER, D.R.J., Arenas, R. \& Diaz-Garcia, F. (eds) VariscanAppalachian dynamics: the building of the Late Paleozoic basement. Geological Society of America, Special Paper 364.

Stuckenberg, A. 1904. Anthozoen und Bryozoen des unteren Kohlenkalkes on Central-Russland. Mémoire du Commité géologique, Saint-Pétersbourg 14, 1-109.

Thomson, J. \& Nicholson, H.A. 1876. Contribution to the study of the chief generic types of the Palaeozoic corals. Annals and Magazine of Natural History 4, 305-309 and 424-429.

ToKAY, M. 1954. Géologie de la Région de Bartin (Zonguldak Turquie du Nord). Bulletin of the Mineral Research and Exploration Institute of Turkey (MTA Bulletin) 46-47, 46-63.

ÜNSALANER-KIRAGLI, C. 1958. Lower Carboniferous corals from Turkey. Journal of the Palaeontological Society of India 3, $53-58$.

VAssiLjuk, N.P. 1960. Lower Carboniferous corals of the Donets Basin. Trudy Academy of Sciences Ukraina USSR, Stratigraphy and Palaeontology 13, 1-179.

Verrill, A.E. 1865. Classification of Polyps. The Annals and Magazine of Natural History 16, 191-197.

Volkova, M.S. 1941. Corals from the Carboniferous of central Kazakhstan. Materialy po geologii i poleznym iskopaemym vostochnogo Kazakhstana 11, 1-119.

Vuillemin, C. 1990. Les Tétracoralliaires (Rugosa) du Carbonifère inférieur du Massif Armoricain (France). 167 pp. Editions du CNRS, Paris.

WeBB, G.E. 1990. Lower Carboniferous coral fauna of the Rockhampton Group, East-Central Queensland. Memoirs of the Association of Australasian Palaeontologists 10, 1-167.

WeBB, G.E. 1994. Paralelism, non-biotic data and phylogeny reconstruction in paleobiology. Lethaia 27, 185-192. DOI 10.1111/j.1502-3931.1994.tb01407.x

WeYER, D. 2000. Korallen im Unterkarbon Deutschlands. $A b$ handlungen und Berichte für Naturkunde 23, 57-91.

Wright, V.P. \& VAnstone, S.D. 2001. Onset of Late Paleozoic glacio-eustasy and evolving climates of low latitude areas: a synthesis of current understanding. Journal of the Geological Society 158, 579-582. DOI 10.1144/jgs.158.4.579

Wu, W.S. \& Zhно, J. 1989. Carboniferous and early Permian Rugosa from western Guizhou and eastern Yunnan, SW China. Palaeontologica Sinica 177(24), 1-224.

Yabe, H. \& HayasaKa, I. 1915. Palaeozoic corals form Japan, Korea and China. Journal of the Geological Society of Tokyo 22, 55-70, 79-109, 127-142.

Yabe, H. \& Hayasaka, I. 1920. Paleontology of southern China. 221 pp. Tokyo Geographical Society, Tokyo.

Yü, C.C. 1933. Lower carboniferous Corals of China. Palaeontologia Sinica 12, 1-211.

Yü, C.C. 1937. The Fenginian Corals of South China. Memoirs of the National Research Institute of Geology 16, 1-111.

YÜ, C.C., Lin, Y.D. \& FAN, Y.N. 1962. Permo-Carboniferous rugose corals from the Qinghai and Xinjiang, China, 13-35. Scientific articles for the commemoration of the $10^{\text {th }}$ anniversary of the Changchun Geological College. Changchun. 